\title{
CARACTERIZAÇÃO HIDROLÓGICA DE UMA MICROBACIA EXPERIMENTAL VISANDO IDENTIFICAR INDICADORES DE MONITORAMENTO AMBIENTAL
}

\author{
NOEMÍ MABEL RODRÍGUEZ ANIDO
}

Dissertação apresentada à Escola Superior de Agricultura "Luiz de Queiroz", Universidade de São Paulo, para obtenção do título de Mestre em Recursos Florestais, com opção em Conservação de Ecossistemas Florestais.

PIRACICABA

Estado de São Paulo - Brasil

Outubro - 2002. 


\title{
CARACTERIZAÇÃO HIDROLÓGICA DE UMA MICROBACIA EXPERIMENTAL VISANDO IDENTIFICAR INDICADORES DE MONITORAMENTO AMBIENTAL
}

\author{
NOEMÍ MABEL RODRÍGUEZ ANIDO \\ Engenheira Florestal
}

Orientador: Prof. Dr. WALTER DE PAULA LIMA

Dissertação apresentada à Escola Superior de Agricultura "Luiz de Queiroz", Universidade de São Paulo, para obtenção de título de Mestre em Recursos Florestais, com opção em Conservação de Ecossistemas Florestais.

PIRACICABA

Estado de São Paulo - Brasil

Outubro - 2002. 


\section{Dados Internacionais de Catalogação na Publicação (CIP)} DIVISÃO DE BIBLIOTECA E DOCUMENTAÇÃO - ESALQ/USP

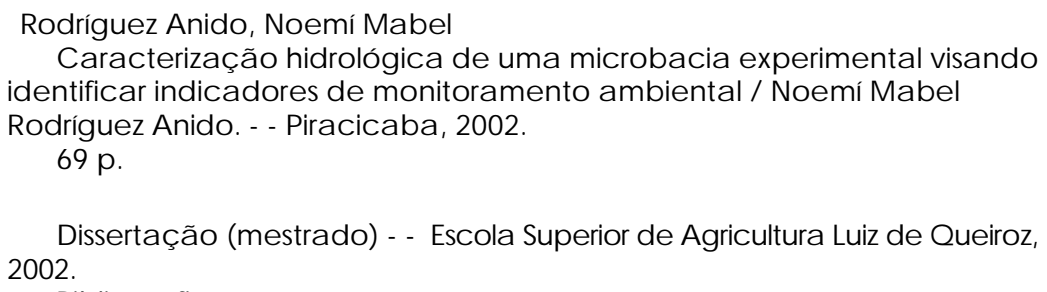

1. Ba cia hidrográfica 2. Ec ossistema sloresta is 3. Ma nejo sustentável 4. Monitoramento ambiental - Indic adores 5. Recursos natura is - Uso I. Título

CDD 551.483 
A mis padres, Enrique y Zulema, a mi hermano, a todos los que me acompañaron $\mathrm{y}$ ayudaron a recorrer este camino.

Caminante son tus huellas el camino y nada más; caminante, no hay camino se hace camino al andar.

$\mathrm{Al}$ andar se hace camino y al volver la vista atrás se ve la senda que nunca se ha de volver a pisar.

Caminante no hay camino si no estelas en la mar.........

\section{Antonio Machado}




\section{AGRADECIMENTOS}

Foram muitas as pessoas e instituições que ajudaram a alcançar este objetivo. É difícil conseguir agradecer a todos e a cada um sem esquecer ninguém. Peço desculpas se acontecer, mas saibam, no entanto, que ficam dentro de meu coração....

Ao Professor Dr. Walter de Paula Lima, por sua orientação e dedicação na condução da pesquisa, e pelo tempo dedicado na correção do português.

Ao Departamento de Ciências Florestais da ESALQ/USP , que possibilitou a realização do curso de pós-graduação.

A la Facultad de Ciencias Agrarias de la UNLZ, que me brindó su apoyo académico y económico para poder realizar esta capacitación.

À FAPESP, processo $\mathrm{N}^{\circ}$ 99/05204-4, pela ajuda econômica para a construção dos coletores de neblinas.

À FEALQ, pelos seis meses de bolsa concedida este ano para poder concluir o trabalho.

Ao Instituto Florestal de São Paulo, por brindar-me suas instalações e o apoio irrestrito para a realização dos trabalhos de pesquisa.

Ao Professor Nilson Vila Nova, por seu tempo e ajuda na eleição da metodologia para a coleta de neblinas.

A Zezé (Dr. Maria José Britto Zakia), por oferecer-me sua casa quando cheguei e por sua hospitalidade, amizade e disposição, em todo momento. 
Ao Eng. Valdir de Cicco pelo convite e incentivo para converter este projeto em realidade, por sua amizade e ajuda em todo o momento.

Aos Pesquisadores Francisco Arcova, Eliane Honda e Maurício Ranzini, por sua ajuda e amizade.

Ao Sr João Batista Amaro dos Santos, técnico do Laboratório de Hidrologia Florestal "Walter Emmerich", por sua dedicação e disposição na coleta dos dados.

A todo o pessoal do Núcleo Cunha, por sua cordialidade e carinho, e ao pessoal de apoio do Laboratório de Hidrologia Florestal "Walter Emmerich", que colaboraram na coleta dos dados.

A Graciela, a Malvina (Coca), a Micky y a Victor, por estar acompañándome desde lejos.

A Eva, Laerte, por sua amizade e companhia em todas as horas.

A Carla, Cecília, Lúcia, Marichu, Raiza, Viviane, Fernando, Pablo, Vianel com os quais compartilhei gratos momentos e que me acompanharam o tempo todo com sua amizade.

A todos os outros amigos brasileiros e estrangeiros pelos bons momentos compartilhados.

A toda mi familia y mis amigos que, a pesar de la distancia, siempre estuvieron presente con su cariño. 


\section{SUMÁRIO}

Página

LISTA DE FIGURAS........................................................................... viii

LISTA DE TABELAS.......................................................................

RESUMO

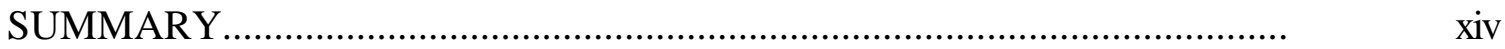

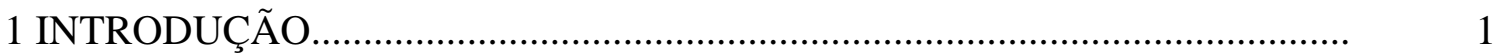

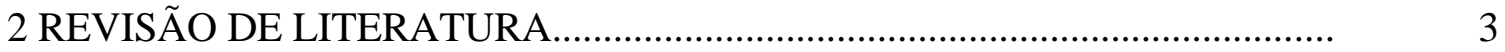

2.1 A Microbacia Experimental no Monitoramento de Indicadores $\quad$........................ 3

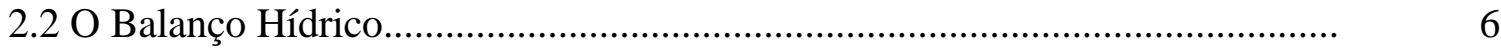

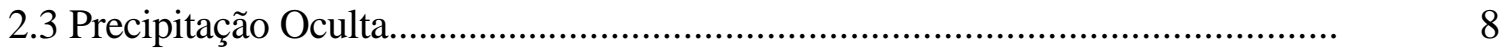

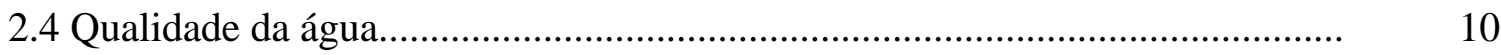

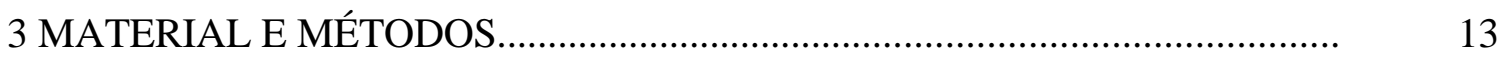

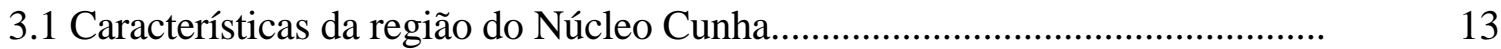

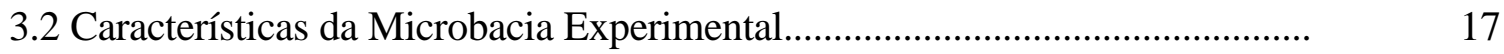

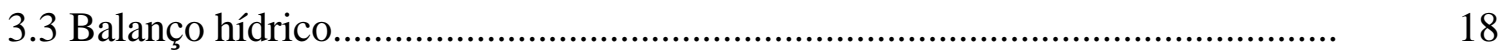

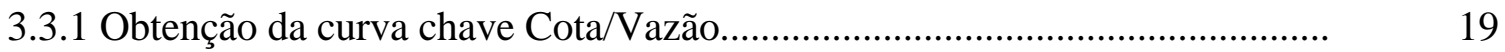

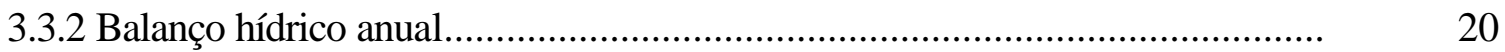

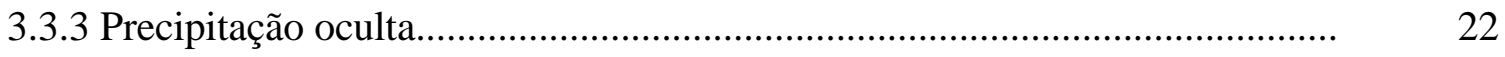

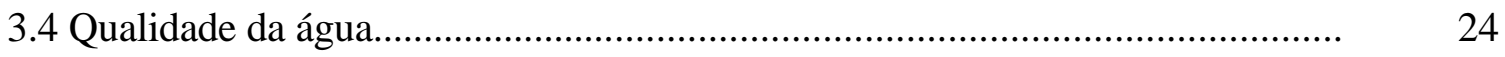




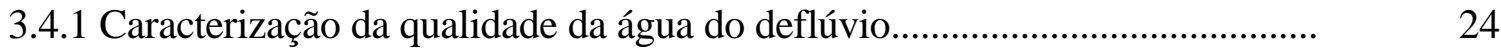

3.4.2 Quantificação das perdas médias de sedimentos em suspensão na água do deflúvio....................................................................................... 25

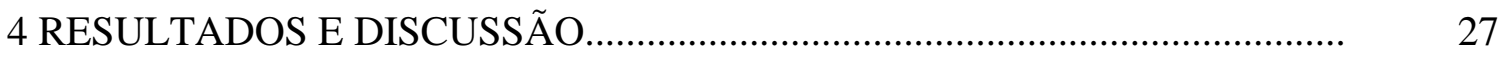

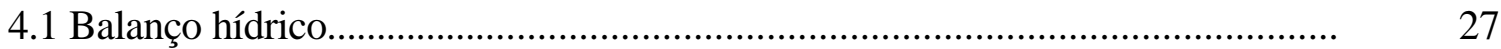

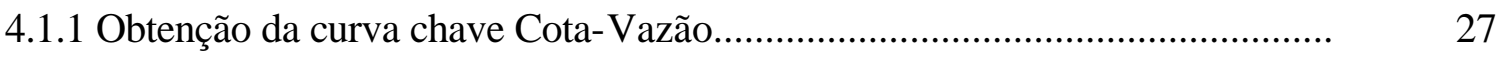

4.1.2 Balanço hídrico anual.......................................................................

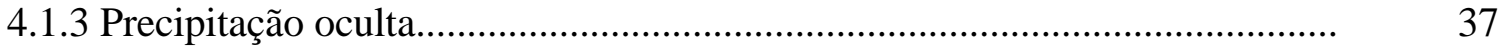

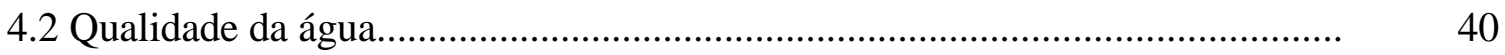

4.2.1 Caracterização da qualidade da água do deflúvio (Turbidez e Cor aparente) $\quad 40$

4.2.2 Quantificação das perdas médias de sedimentos em suspensão na água do deflúvio........................................................................................ 48

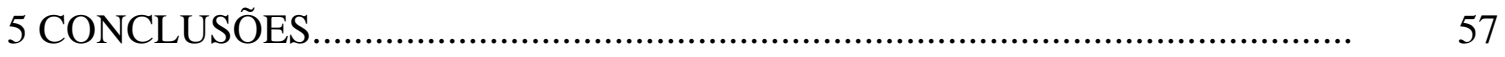

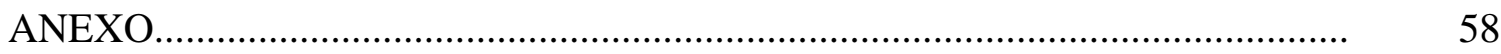

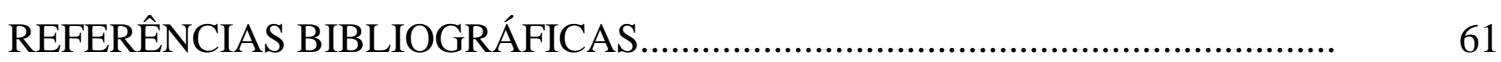




\section{LISTA DE FIGURAS}

Página

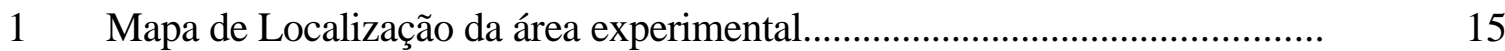

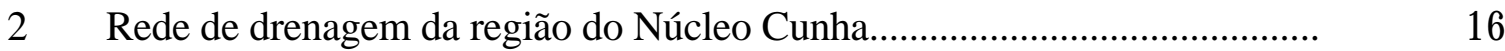

3 Localização das microbacias experimentais que constituem o Laboratório de Hidrologia "Walter Emmerich" do Núcleo Cunha, ressaltando a

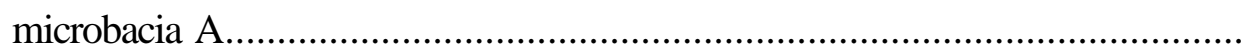

4 Mapa da microbacia A destacando-se os cursos de água, as principais curvas de nível e a localização do vertedor. (Extraído de Compartment Map for experimental watershed JICA-IF E:1/5000)

5 Pontos da amostragem da velocidade do fluxo da água no vertedor

6 Coletor de neblinas localizado na estação meteorológica do Núcleo Cunha.

7 Sistema de coletas de amostras em duas linhas paralelas

8 Representação logarítmica do modelo de regressão linear que relaciona a cota fluviométrica com a vazão. logh: logaritmo decimal da cota fluviométrica, logvazao: logaritmo decimal da vazão.

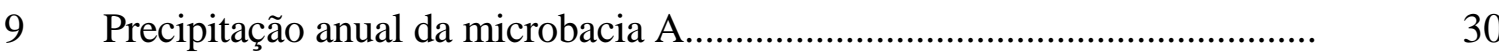

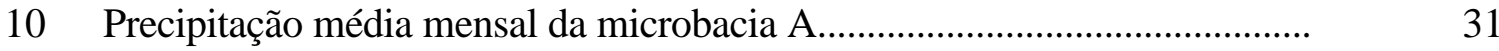

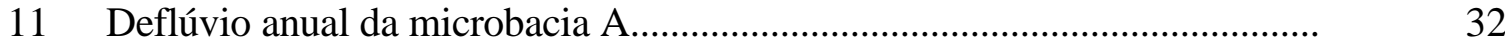


12 Deflúvio médio mensal da microbacia A....................................................

13 Regime de precipitação e deflúvio médios mensais da microbacia A. Período de recarga e excesso hídrico

14 Relação entre precipitação (PP), deflúvio e evapotranspiração (ET) da microbacia A segundo anos hídricos.

15 Captação de neblinas pelo dossel florestal expresso como volume $(\mathrm{cm} 3)$ de água coletada pelo coletor de neblinas, pelo pluviômetro e pelo pluviógrafo colocados na Estação Meteorológica do Núcleo Cunha Indaia, Parque Estadual da Serra do Mar - SP........................................

16 Flutuações da turbidez (T), medida em unidades FTU, e da cor aparente (CA), medida em unidades de PtCo, da água do deflúvio da microbacia $\mathrm{A}$, no período Setembro de 2000 a abril de 2002 .............................................

17 Turbidez média da água do deflúvio segundo classe de precipitação

18 Cor aparente média da água do deflúvio segundo classe de precipitação.

19 Hidrograma correspondente ao evento ocorrido o dia 10/01/01. P: precipitação, Qt: escoamento total, Qd: escoamento direto, e Qb: escoamento base; expressos em mm..........................................................

20 Turbidez média mensal das coletas semanais da água do riacho da microbacia A. ICS: limite superior do intervalo de confiança, II: limite inferior do intervalo de confiança

21 Turbidez média mensal da água do riacho da microbacia A. ICS: limite superior do intervalo de confiança, ICI: limite inferior do intervalo de confiança 
22 Cor aparente média mensal das coletas semanais da água do riacho da microbacia A. ICS: limite superior do intervalo de confiança, ICI: limite

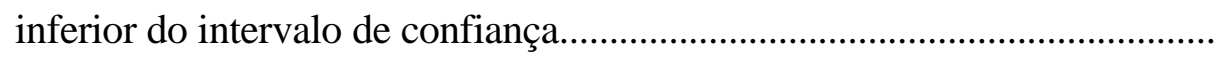

23 Cor aparente média mensal da água do riacho da microbacia A. ICS: limite superior do intervalo de confiança, ICI: limite inferior do intervalo de confiança.

24 A: Turbidez média mensal em unidades FTU e precipitação média mensal da água do riacho da microbacia A. B: Cor aparente média mensal em unidades PtCo e precipitação média mensal da água do riacho da

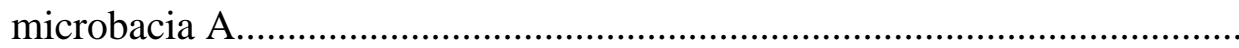

25 Concentração em $\mathrm{mg} \mathrm{l}^{-1}$ dos sedimentos em suspensão totais, sedimentos em suspensão fixos e sedimentos em suspensão voláteis, da água do riacho da microbacia A....................................................................................

26 Sedimentos em suspensão médios mensais em $\mathrm{mg} 1^{1}$ das coletas semanais da água do riacho da microbacia A. ICS: limite superior do intervalo de confiança, ICI: limite inferior do intervalo de confiança..

27 Sedimentos em suspensão médios mensais em $m g 1^{1}$ da água do riacho da microbacia A. ICS: limite superior do intervalo de confiança, ICI: limite

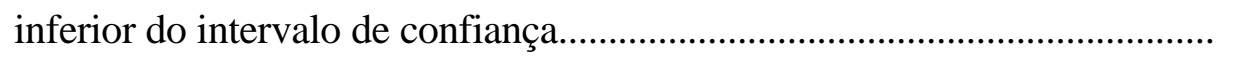

28 Sedimentos em suspensão fixos médios mensais em $\mathrm{mg}^{-1}$ da água do riacho da microbacia A. ICS: limite superior do intervalo de confiança,

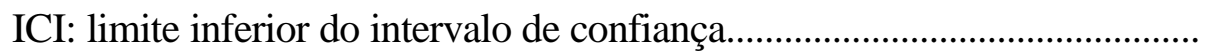

29 Sedimentos em suspensão voláteis médios mensais da água do riacho da microbacia A. ICS: limite superior do intervalo de confiança, ICI: limite

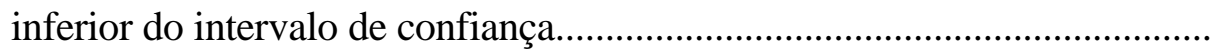

30 Sedimentos em suspensão médias mensais de suas frações fixas e voláteis, precipitação mensal média e deflúvio mensal médio. 


\section{LISTA DE TABELAS}

Página

1 Valores de altura da lâmina de água, área da seção molhada, velocidade média da água e vazões calculadas em campo...........................................

2 Estimação da evapotranspiração segundo o método de Thornthwaite e Matter (1955) e pelo balanço de massa.........................................................

3 Resumo do análise dos hidrogramas de eventos de chuva acontecidos no período outubro-2000 a abril-2002 ........................................................ 36

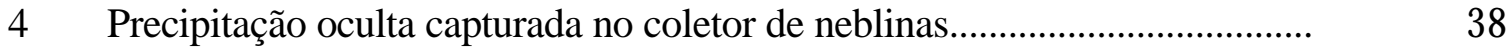

5 Valores mínimos, médios e máximos da turbidez e da cor aparente da água do deflúvio do riacho da microbacia A.........................................................

6 Concentrações de sedimentos em suspensão totais sedimentos em suspensão fixos e sedimentos em suspensão voláteis em mg.l-1, das coletas nas garrafas de espera, segundo classe de precipitação para diferentes alturas da lâmina de água, e suas respectivas participações percentuais das frações fixas e voláteis.

7 Matriz dos coeficientes de determinação das variáveis de quantidade e qualidade de água do riacho da microbacia A 


\title{
CARACTERIZAÇÃO HIDROLÓGICA DE UMA MICROBACIA EXPERIMENTAL VISANDO IDENTIFICAR INDICADORES DE MONITORAMENTO AMBIENTAL
}

\author{
Autor: NOEMÍ MABEL RODRÍGUEZ ANIDO \\ Orientador: Prof. Dr. WALTER DE PAULA LIMA
}

\section{RESUMO}

$\mathrm{Na}$ busca de critérios e indicadores hidrológicos que possam ter uma posterior utilização prática para o monitoramento do manejo sustentável dos recursos naturais, e considerando a bacia hidrográfica como unidade de manejo, o presente trabalho visa caracterizar o comportamento hidrológico da microbacia A, localizada no Núcleo Cunha do Parque Estadual da Serra do Mar, contendo vegetação natural em estágio avançado de regeneração, visando identificar indicadores de monitoramento ambiental, em termos de suas flutuações naturais em ecossistemas não perturbados. A turbidez, a cor aparente, e a concentração de sedimentos em suspensão, são parâmetros importantes para avaliar a qualidade da água do deflúvio. Assim, foram estes os escolhidos no presente estudo para que se pudesse analisar seu comportamento como indicadores para o monitoramento ambiental. Para a caracterização hidrológica quantitativa, foi necessário determinar previamente a curva chave do vertedor, sendo que a curva obtida está representada pela

equação $\mathrm{Q}=0,0561 \mathrm{H}^{2,3778}$, com um $\mathrm{r}^{2}=0,9872$. Da análise dos dados pluviométricos e 
fluviométricos de 8 anos, foram determinados os componentes do balanço hídrico anual. A precipitação média anual foi de $1832 \mathrm{~mm}$, observando-se diferença entre a estação úmida (setembro a março), onde se produz o $84 \%$ das precipitações, e a estação seca (abril a agosto). O deflúvio médio anual foi de $1279 \mathrm{~mm}$, as perdas médias anuais ocasionadas pela evapotranspiração foram de $553 \mathrm{~mm}$, correspondendo a $32 \%$ da precipitação. Em razão da relativamente baixa evapotranspiração anual que prevalece na área, e a freqüente ocorrência de neblinas; analisou-se a possibilidade de estar havendo uma entrada adicional de água ao balanço hídrico da microbacia representada pelo processo de captura de neblinas pelo dossel florestal (precipitação oculta). Os resultados estariam indicando um acréscimo na precipitação próximo a $8 \%$. Os resultados dos parâmetros de qualidade da água (turbidez, cor aparente e sedimentos em suspensão), indicam que as flutuações destes parâmetros estão altamente relacionadas com os picos de vazão ocasionados pelas precipitações estivais. Foram obtidos valores máximos de turbidez, cor aparente e sedimentos em suspensão de 173 FTU, 550 PtCo e 465,2 mg 1, no mês de janeiro, e mínimos de 2 FTU, 6 PtCo e 0 mg 1, respectivamente. Assim, podese considerar estes intervalos como válidos para uma área sem perturbação, podendo servir de referencial para o monitoramento do manejo florestal sustentável nesta região. 


\title{
HYDROLOGICAL CHARACTERISTICS OF AN EXPERIMENTAL CATCHMENT FOR THE IDENTIFICATION OF INDICATORS OF ENVIRONMENTAL MONITORING
}

\author{
Autor: NOEMÍ MABEL RODRÍGUEZ ANIDO \\ Adviser: Prof. Dr. WALTER DE PAULA LIMA
}

\section{SUMMARY}

With the purpose of identifying hydrological indicators suitable for the environmental monitoring of sustainable forest management and taking into account the catchment as a systemic base of management planning, the aim of the present study is to characterize the hydrological functioning of an experimental catchment covered with undisturbed natural forest, located at the Serra do Mar State Park, State of São Paulo, Brazil, and thus identify hydrological parameters, in terms of their natural range of variation in such conditions, which could be used as suitable indicators for environmental monitoring. Among the parameters potentially suitable for this purpose, this study was carried out with the following water quality parameters: turbidity, color and suspended sediment concentration. The data analyzed encompass a period of 8 years of precipitation and streamflow continuous measurements. Initially, a rating curve was developed for the weir, which gave the following calibration equation: 
$\mathrm{Q}=0,0561 \mathrm{H}^{2,3778}$, with $\mathrm{r}^{2}=0,9872$. Average annual precipitation for the period was $1832 \mathrm{~mm}, 84 \%$ of which occurred during the rainy season of September through March. Average annual streamflow for the period was $1279 \mathrm{~mm}$. Considering the simplified water balance equation, this resulted in a total water loss of $553 \mathrm{~mm}$. The relatively low value of evapotranspiration obtained, which was also observed in other experimental catchments in this mountain region, an attempt was done to measure the additional input of rainwater as fog drip in the area, which would also to be included in the water balance calculations. The results showed an approximate additional amount of $8 \%$ of the average annual precipitation measured in the conventional rain gauges. The water quality results indicate that the fluctuations of turbidity, color and suspended sediments are correlated with the peak flows, with maximum values 173 FTU, 550 PtCo and 465,2 $\mathrm{mg} \mathrm{l}^{-1}$, respectively, occurring during the rainy month of January. On the other hand, the minimal values corresponded to $2 \mathrm{FTU}, 6 \mathrm{PtCo}$ and $0 \mathrm{mg} \mathrm{l}^{-1}$, respectively. Therefore, such range of variation for these studied water quality parameters could be considered indicative of the natural range of variation of catchments well protected with undisturbed natural forest cover in the region. 


\section{INTRODUÇÃO}

Dada a importância que hoje apresentam a conservação do meio ambiente e dos recursos naturais, para que possam ser também aproveitados pelas gerações futuras, é necessário conhecer em profundidade o funcionamento dos ecossistemas e os fatores que atuam sobre eles, a fim de obter referenciais que permitam a avaliação da magnitude dos impactos ambientais decorrentes da intervenção do homem sobre os mesmos.

As florestas desempenham um papel muito importante na captação e distribuição da água de chuva nas bacias hidrográficas, no processo de suprimento de água para a recarga dos aqüíferos, assim como na regulação do escoamento de água das microbacias (Arcova \& Cicco, 1997).

As práticas de manejo de microbacias hidrográficas baseiam-se na hidrologia florestal, que trata dos efeitos da floresta e a vegetação associada sobre o ciclo hidrológico. Os trabalhos realizados em microbacias hidrográficas experimentais proporcionam os dados necessários para a avaliação das técnicas de manejo hidrologicamente sustentáveis (Fujieda, 1987).

Para poder avaliar o efeito que poderia ter qualquer perturbação na microbacia, é necessário antes, conhecer muito bem as características do ecossistema em suas condições naturais de equilíbrio, a fim de estabelecer as condições hidrológicas e de qualidade da água no ecossistema natural, para posteriormente poder fazer a comparação com aqueles onde o homem intervém. A análise destes aspectos do ecossistema envolve características de clima, geomorfologia, solo, vegetação, deflúvio e evapotranspiração, com o que pode-se quantificar os processos hidrológicos da microbacia e correlacioná- 
los às diferentes variáveis relacionadas com a quantidade e qualidade da água, assim como sua dinâmica.

As microbacias experimentais localizadas no Núcleo Cunha, por suas condições de proteção florestal mantidas inalteradas há longo tempo, podem ser consideradas ecossistemas naturais em equilíbrio e íntegros. Desta forma, a identificação de indicadores hidrológicos nestas condições, assim como de sua variabilidade natural, a partir da análise de dados acumulados de monitoramento hidrológico em andamento há vários anos, podem oferecer um marco referencial para a avaliação de impactos ambientais decorrentes do manejo florestal

O presente trabalho tem por finalidade a caracterização do comportamento hidrológico de uma microbacia, localizada no Núcleo Cunha do Parque Estadual da Serra do Mar, numa área de Mata Atlântica, com vegetação de Floresta Latifoliada Perenifolia não perturbada.

Aliada a esta caracterização hidrológica de uma microbacia contendo cobertura florestal de Mata Atlântica, que do ponto de vista do funcionamento do ecossistema poderia considerar-se não perturbada, o presente projeto visa também identificar algumas variáveis hidrológicas, em termos de suas flutuações naturais em ecossistemas não perturbados, que possam ser utilizadas como indicadores da saúde ambiental de uma microbacia que, por sua vez, possam ser integradas a programas de monitoramento ambiental para a busca do manejo sustentável, compatível com o uso dos recursos naturais pelo homem. 


\section{REVISÃO DE LITERATURA}

\subsection{A Microbacia Experimental no Monitoramento de Indicadores}

O homem é parte integrante dos ecossistemas e depende deles para sobreviver e para seu bem-estar. Os ecossistemas são fonte de vida e suporte para a sobrevivência a longo prazo dos homens e outras formas de vida (Kaufmann et al. 1994). Os mesmos autores comentam que a intervenção humana não deve produzir impactos que incidam na sustentabilidade do ecossistema, degradando significativamente componentes que afetem suas capacidades.

O conceito de manejo florestal sustentável, segundo Lima (1996), deve envolver medidas de planejamento que contemplem o uso dos recursos florestais visando a produção de bens e serviços, baseado num contexto ecológico, econômico e social.

Um dos pilares do manejo sustentável diz respeito a aspectos ecológicos, englobados no princípio de manutenção da integridade do ecossistema. No contexto da microbacia, esta manutenção da integridade envolve a manutenção de seu funcionamento hidrológico, que significa tanto perpetuar os processos hidrológicos (deflúvio, regime de vazão e qualidade da água), assim como manter sua capacidade natural de suporte produtivo (biogeoquímica), a perpetuação da diversidade ecológica (vegetação ciliar protegiendo as zonas riparias, reservas de vegetação natural), e sua estabilidade e capacidade de resistir a mudanças ambientais (resiliência) ( Lima, 1996; Lima \& Zakia, 1998). Também, segundo estes autores, a noção da microbacia como unidade ecossistêmica de planejamento das atividades florestais possibilita a 
identificação de indicadores hidrológicos condizentes com o manejo sustentável. Seu estudo, no conjunto, fornece uma medida da conservação da saúde ambiental da microbacia.

Prabhu et al. (1998) discute o papel dos indicadores e ressalta a importância de sua seleção. Deve-se levar em conta que um indicador tem, antes de tudo, de ser uma ferramenta de informação, além de se constituir como parte integrante do manejo florestal sustentável, através de sua função no processo de monitoramento, considerando sempre a complexidade dos ecossistemas florestais. Segundo este autor, um bom indicador de manejo florestal sustentável caracteriza-se por:

- ser holístico em sua essência;

- ser relevante para a meta de monitoramento do Manejo Florestal Sustentável;

- no conjunto, os indicadores selecionados devem ser suficientes para produzir informações seguras sobre as conseqüências ecológicas e sociais do manejo, e especialmente úteis para implementar o manejo adaptativo;

- os efeitos compensatórios não lineares entre os diferentes indicadores devem ser conhecidos (complexidade do ecossistema) e

- devem ser transparentes e aceitos pela sociedade.

Tendo em vista o papel fundamental de funcionar como ferramentas para o monitoramento ambiental, um requisito importante para a seleção de indicadores que sejam úteis para guiar as ações de manejo na direção correta, bem como proporcionar medições confiáveis que permitam obter as metas, diz respeito à capacidade destes indicadores de relacionar causas e efeitos (Mc. Cool \& Stankey, 1998).

O uso de indicadores de qualidade de água permite correlacionar as alterações ocorridas na microbacia sejam tanto de origem antrópico como natural, tentando acompanhar a possível deterioração da qualidade das águas no tempo. Para uma interpretação ecológica deste fenômeno, é necessário estabelecer um sistema de monitoramento e a utilização de métodos simples que produzam informações objetivas e interpretáveis (Toledo e Nicolella, 2002) 
Câmara (1999) considera que a separação dos efeitos das operações de manejo florestal daqueles produzidos pelas variações naturais do ecossistema se torna difícil quando os intervalos de tempo são pequenos. No entanto, intervalos de confiança mas amplos refletem uma maior sensibilidade do indicador aos fatores naturais do ambiente. As microbacias hidrográficas delimitam boa parte dos mecanismos de funcionamento dos ecossistemas e as características de um curso de água refletem as características de sua bacia de drenagem. A hidrologia florestal estuda os efeitos da floresta e da vegetação associados sobre o ciclo hidrológico. Os trabalhos realizados em microbacias experimentais proporcionam dados para a avaliação das técnicas de manejo hidrologicamente sustentáveis (Fujieda, 1987; Pires \& Santos, 1995).

Pesquisas desenvolvidas em microbacias experimentais demostraram que $o$ uso de solo e os diversos tratamentos aplicados à cobertura vegetal afetam tanto a quantidade do deflúvio produzido quanto o regime de vazão das microbacias. Em certas situações, a quantidade de água do deflúvio pode aumentar pelo manejo da vegetação, em outras condições os picos de vazão podem ser reduzidos (Reinhart \& Pierce,1964).

As florestas desempenham um papel fundamental no recebimento e distribuição da água das chuvas nas microbacias. A produção de água, o regime fluviométrico e a qualidade da água da microbacia são significativamente influenciados pelo manejo da cobertura florestal (Stednick, 1996; Arcova \&Cicco,1997).

Para a implementação de um plano de manejo florestal sustentável, é relevante a quantificação prévia dos parâmetros dinâmicos do ecossistema antes da intervenção. Ou seja, é necessário conhecer em profundidade as características do ecossistema nas condições naturais de equilíbrio, para posteriormente poder comparar e avaliar os efeitos que poderiam acontecer em consequiência de uma perturbação antrópica na microbacia (Sarrailh,1990). 


\subsection{O Balanço Hídrico}

Estudos envolvendo as relações entre florestas e os recursos hídricos tem como ponto inicial a realização do balanço hídrico. Mesmo nas microbacia menores, existe sempre um área de terreno que recebe água de chuva, evapora parte desta e o restante compõe o deflúvio ou a recarga de água subterrânea (Hewlett, 1982).

A avaliação de alterações no regime hídrico em uma microbacia só pode ser feita caso exista um registro prévio de suas características hidrológicas, e que esse período seja suficientemente longo para que se possa avaliar e quantificar a magnitude desta alteração (Scardua, 1994).

Ranzini (1990) considera que do ponto de vista hidrológico o deflúvio de uma microbacia pode ser considerado o produto residual do ciclo hidrológico, o qual é influenciado por três grandes grupos de fatores: clima, fisiografia, cobertura e uso do solo.

O balanço hídrico envolve a quantificação dos componentes do sistema visando o melhor entendimento de seu comportamento e baseia-se no principio de conservação de massa, sendo analisado pelos insumos, ou entradas de água, e pelas saídas de água do sistema (Pereira et al. 1997; Righetto, 1998, Tucci, 2000; Zakia,1987), resumido na seguinte equação hidrológica fundamental:

$\mathrm{Q}_{\mathrm{e}}-\mathrm{Q}_{\mathrm{s}}=\mathrm{dV} / \mathrm{dt}$

onde:

$\mathrm{Q}_{\mathrm{e}}=$ vazão de entrada; $\quad$ Qs = vazão de saída;

$\mathrm{dV}=$ variação de armazenamento de água; $\quad \mathrm{dt}=$ intervalo de tempo.

As possíveis entradas no sistema incluem a chuva, o orvalho, o escoamento superficial, a drenagem lateral e a ascensão capilar, enquanto que as possíveis saídas incluem a evapotranspiração, o escoamento superficial, a drenagem lateral e a drenagem profunda (Pereira et al., 1997). 
Do balanço hídrico pode-se obter informações sobre as relações hídricas dentro do sistema, tais como a evapotranspiração potencial, a atual, os períodos de déficit hídrico e os períodos com excessos, a armazenamento de água no solo, a quantidade de água que escoa fora do sistema, etc. (Lima, 1971). Portanto, caracteriza-se como uma ferramenta muito importante para a analise do funcionamento hidrológico de uma microbacia.

Estudos sobre o balanço hídrico e o balanço geoquímico podem ser desenvolvidos a partir de uma condição experimental satisfatória. A quantificação correta da entrada e da saída de água na microbacia é muito importante. A entrada pode ser obtida pela instalação de um número e de uma disposição espacial adequada de pluviômetros (Shimomichi et al., 1987). Quanto à saída de água da bacia, esta é medida em estações fluviométricas equipadas com vertedores padronizados e aferidos em laboratório, que permite a obtenção de valores da relação cota-vazão do curso de água. Quando isso não é possível, recomenda-se fazer a calibragem do vertedor já instalado na própria microbacia, por intermédio de medições de velocidade da água e a área da seção molhada do vertedor para diferentes cotas fluviométricas (Cicco et al.,1987).

Segundo Herschy (1985), o erro na determinação da vazão pode ser definido como a diferença entre a medida do escoamento e o valor exato. Este valor exato do escoamento é desconhecido e somente pode ser estimado pelo volume medido.

A relação cota-vazão dada pela curva-chave do vertedor deve ser definida em todo o intervalo de definição da calibragem. Como em geral este número de medições é insuficiente, a curva muitas vezes deve ser extrapolada, e no caso é recomendado fazer a extrapolação na direção superior (águas médias e altas) (Tucci, 2000). De uma forma geral, quanto maior a cota fluviométrica maior a velocidade da água. A maior dificuldade na medição das velocidades deriva do fato de ser essa grandeza essencialmente variável de ponto para ponto da seção e ao longo do tempo. As velocidades da água em uma seção transversal de um canal decrescem da superfície para o fundo e do centro para as margens (Garcez \& Alvarez,1988). 
De acordo com as pesquisas desenvolvidas em outras microbacias experimentais localizadas na área do presente estudo, a maior parte da precipitação permanece no solo, alimentando gradualmente o escoamento do riacho. Os escoamentos totais variam entre $70 \%$ e $89 \%$ da precipitação. A evapotranspiração está ao redor do $30 \%$ da precipitação, tendo valores médios anuais de $682,1 \mathrm{~mm} \mathrm{ano}^{-1}$ para a microbacia D em dez anos de observações. Para a microbacia B, o valor médio é de 553,6 mm ano ${ }^{-1}$, para um período de 5 anos de observações, chegando a ter um valor extremo de 10,46\% da precipitação (Cicco et al.,1989; Cicco \& Fujieda,1992; Fujieda et al., 1997).

Como estes valores da evapotranspiração são comparativamente mais baixos do que a maioria dos dados do balanço hídrico de outras regiões, e levando em conta que a umidade relativa da área é muito alta, segundo os dados da estação meteorológica entre janeiro de 1998 até janeiro de 2000 a umidade relativa média mensal varia entre 86,79\% até 96,21\%, considerou-se importante, então, determinar a possibilidade de estar havendo, de uma forma efetiva, o processo de captação de neblina pela cobertura florestal, referida como precipitação oculta, à semelhança do que já foi observado em outras regiões de condições climáticas semelhantes, e que será discutido com mais detalhe no item seguinte.

\subsection{Precipitação Oculta}

Trabalhos desenvolvidos na região do presente estudo deram resultados de evapotranspiração relativamente baixa, ao redor de $30 \%$ para as microbacias D e B, o que corresponderia a uma evapotranspiração média de cerca de $600 \mathrm{~mm}$ (Cicco et al.,1989; Cicco \& Fujieda,1992; Fujieda et al., 1997).

Segundo Furian (1994), as amplitudes térmicas ocorrentes na região e a presença da floresta resultaria numa precipitação oculta considerável ao favorecer a constante umidade no meio. Tratando-se de uma região montanhosa, onde a umidade relativa do ar é normalmente alta (médias próximas a 90\%), considera-se importante determinar a possibilidade de ocorrência, de uma forma efetiva, do processo de captação 
de neblina pela cobertura florestal, referida como precipitação oculta no balanço hídrico da microbacia.

Em algumas áreas, as condições microclimáticas dão lugar à permanência constante de nuvens a altitudes de 400 a 1.200 metros sobre o nível do mar, consistindo de gotas pequenas, de diâmetro variando de 1 a 40 micrômetros, que podem ser levadas facilmente pelos ventos às montanhas costeiras (Mukerji et al., 1993).

Diversos autores têm verificado que em regiões montanhosas, com temperaturas moderadas e elevados conteúdos de umidade na atmosfera resultam em condições microclimáticas necessárias para a formação de florestas de neblinas (“cloud forest"), especialmente onde estas condições são influenciadas por sistemas orográficos e pelos ventos marinhos carregados de umidade. Esta neblina é captada fisicamente pelo dossel e a precipitação ocorre então sob a forma de gotejamento e escoamento pelo tronco, referida como precipitação oculta. A precipitação efetiva total nestas áreas pode, então, ser maior do que aquela medida convencionalmente (Vogelmann,1973; Zadroga,1981; Holdridge,1982).

Quando neblinas ou nuvens estão presente, existe um processo de captação de água similar ao de interceptação. O termo interceptação de neblinas ("cloud interception") implica um ganho líquido de água para o ecossistema. Em condições úmidas, a precipitação interna encontra-se entre $65-80 \%$ da chuva incidente em florestas montanhosas, dado este que pode ser incrementado até $130 \%$ em exposições como os topos montanhosos com musgos ou vegetação de porte baixo. Embora, a quantidade de água captada pela floresta seja difícil de medir diretamente em presença de chuvas, estimativas podem ser feitas comparando-se as quantidades típicas de precipitação líquida em florestas de montanha com as freqüências de nuvens (Bruijnzeel \& Hamilton, 2000).

Zimmermann \& Zimmermann (2002) sugerem que as quantidades de água aumentem exponencialmente com o incremento da frequiência das neblinas em altitudes superiores aos $700 \mathrm{~m}$, e que estudos realizados entre os anos 80 e 90 em vários locais 
montanhosos da Alemanha mostram que quando as freqüências de neblinas são superiores a $30 \%$ de horas de neblinas no ano, as entradas de água por estas igualariam aquela produzida pela precipitação normal.

Volgemann (1973), num trabalho realizado na Sierra Madre Occidental, no México, determinou a alta incidência que a captação deste tipo de precipitação pode ter durante os meses secos, chegando a incrementá-la até um valor máximo de 79,1\%, representando $262 \mathrm{~mm}$ de precipitação por neblinas, em comparação aos $221 \mathrm{~mm}$ de precipitação normal. Goodman (1985), em trabalho semelhante desenvolvido no centro da Califórnia, coletou com um coletor cilíndrico de 63,6 cm, 511 litros num período sem precipitações de 1253 dias. Sem dúvida, valores relativos como estes podem resultar em alterações significativas nos componentes do balanço hídrico.

\subsection{Qualidade da água}

Os estudos quantitativos do balanço hídrico devem ser complementados com aqueles correspondentes à qualidade da água, já que é muito direta a influência das florestas e do manejo florestal sobre a qualidade dos recursos hídricos. A qualidade da água deve ser definida em termos de suas características físicas (cor, odor, sabor, turbidez, temperatura, $\mathrm{pH}$, condutividade, dureza, etc.), químicas (íons e substâncias em solução na água, tais como cálcio, magnésio, ferro, alumínio, fósforo e nitrogênio) e biológicas.

A água, ao mover-se pelos diferentes compartimentos de uma microbacia, tem sua qualidade alterada, e qualquer alteração nas condições da microbacia hidrográfica pode causar alterações significativas na qualidade da água (Arcova \& Cicco, 1999; Hatch, 1976). A água que emana de microbacias em regiões de florestas não perturbadas é, em gerál, de boa qualidade e com baixa concentração de nutrientes dissolvidos e sedimentos em suspensão. Por outro lado, as práticas da exploração florestal podem produzir degradação de efeito prolongado na qualidade da água (Brown, 1988; O’Loughlin,1994). 
Assim, a qualidade da água em determinado ponto de um rio é produto da qualidade da água em um ponto anterior modificada por diversos fatores atuantes no trecho que separa os pontos, tais como as características físicas do leito do rio e suas características geomorfológicas, a mistura da água com qualidades diferentes, a presença de vegetação ciliar, o regime climático,a presença de comunidades e pelas interferências antrópicas. (Arcova \& Cicco, 1999; Hatch, 1976; Sé, 1992)

Dentre outros parâmetros significativos de avaliação da qualidade da água a turbidez, a cor e as concentrações de sedimentos em suspensão são parâmetros importantes tanto no que diz respeito ao processo de tratamento da água para fins de abastecimento público, quanto para o monitoramento das práticas de manejo florestal (Wetzel \& Likens, 1991; CONAMA, 1992).

A turbidez define a alteração na penetração da luz em uma amostra da água causada por partículas em suspensão, material coloidal como argilas, partículas finas tanto de origem orgânica como inorgânica, plâncton e outros organismos microscópicos.

A cor da água é função tanto da presença de íons metálicos (principalmente Fe e Mn), como de húmus (ácidos húmicos, etc.) e pequenas partículas (argilas, coloides), plâncton, algas e resíduos industriais, parte dos quais podem ser removidos por filtração.

Os sedimentos em suspensão referem-se às porções de materiais retidas nos filtros depois da passagem de uma amostra de água. Destes pode-se separar duas porções: os sedimentos fixos, que é o termo aplicado ao resíduo do total de sedimentos depois de ser calcinado a uma temperatura específica e por um tempo determinado, e os sedimentos voláteis, que correspondem ao peso perdido por ignição. Esta determinação de sólidos fixos e voláteis não distingue precisamente entre matéria inorgânica e orgânica, já que as perdas por ignição não estão confinadas à matéria orgânica, mesmo porque pode incluir a decomposição ou volatilização de algumas sais minerais (Hem, 1970; APHA, 1995). 
Certas quantidades de sedimentos em suspensão são naturais em algumas microbacias, mas podem incrementar-se muito em decorrência de alguns eventos naturais, como os incêndios em áreas florestais, ou a ação do homem na utilização das florestas (Binkley \& Brown,1993).

Experimentos em microbacias têm esclarecido a respeito da magnitude dos efeitos do manejo florestal sobre a qualidade da água. Nas práticas silviculturais de reflorestamento e colheita florestal, os maiores impactos são causados pelos sedimentos provenientes das estradas e carreadores, como verificado em vários estudos (Lull \& Reinhart,1972; Anderson et al.,1976; Swift, 1988; Binkley \& Brown,1993).

Douglas \& Swank (1975) demostram como a exploração florestal pode afetar drasticamente a quantidade de sedimentos em suspensão na água, comparando uma microbacia florestada com uma outra submetida a corte raso. Nesta última, as quantidades aumentaram entre 10 a 20 vezes. Os sedimentos em suspensão na microbacia protegida foram de $350 \mathrm{ppm}$ enquanto que na microbacia submetida a corte raso foram de $5700 \mathrm{ppm}$. As concentrações de partículas orgânicas e inorgânicas nos sedimentos são marcadamente superiores na exploração florestal, pelas perturbações mecánicas produzidas pelas máquinas. Os sedimentos orgânicos predominam em áreas naturais, diferenciando-se dos sedimentos inorgânicos que geralmente refletem ações erosivas derivadas da atividade antrópica. 


\section{MATERIAL E MÉTODOS}

\subsection{Características da região do Núcleo Cunha}

A Mata Atlântica ocupava no passado $12 \%$ do território do Brasil. Esta floresta explorada desde o início da colonização foi em parte substituída pela agricultura e pelos centros urbanos. Hoje, somente cerca de 8\% da Mata Atlântica original do estado de São Paulo está protegida, e estas áreas continuam sob pressão antrópica.

As porções altas do Vale do Paraíba apresentam relevo montanhoso e sofrem um processo gradativo de degradação de seus solos, em função do uso inadequado. Historicamente, este processo foi desencadeado ao substituir-se a vegetação florestal natural pela cultura do café e, posteriormente, pelo uso na pecuária extensiva de leite com baixa produtividade, que ainda hoje predomina. Como conseqüência, estas áreas encontram-se em adiantado estágio de degradação, com acentuados processos erosivos e movimentos de solos, que provocam a sedimentação e assoreamento de cursos de água e reservatórios, mudança do regime de descarga dos rios e a deterioração da qualidade da água para diversos fins, comprometendo assim os recursos hídricos (Arcova \& Cicco, 1999; Fujieda et al. 1993).

Os processos hidrológicos na Serra do Mar vêm sendo pesquisados pelo Instituto Florestal de São Paulo por mais de uma década, com a criação do Laboratório de Hidrologia Florestal Eng. ${ }^{\circ}$ Agr. Walter Emmerich. Dentre os vários objetivos dos estudos está a caracterização do deflúvio de suas microbacias experimentais, que pode gerar informações úteis ao manejo e a recuperação das microbacias da região de entorno 
do Laboratório no município de Cunha (Cicco \& Fujieda, 1992; Arcova, 1996; Arcova \& Cicco,1997; Arcova et al. 1998; Fujieda et al., 1997).

O núcleo Cunha, com 2.854 ha, está inserido no Parque Estadual da Serra do Mar, administrado pelo Instituto Florestal de São Paulo (órgão da Secretaria de Estado do Meio Ambiente) sendo, portanto, uma área de preservação dos recursos naturais, representando um dos poucos locais do planalto Atlântico ainda recoberto pela vegetação original. Estas condições fazem com que o Núcleo Cunha ofereça valiosas informações sobre os diversos componentes do meio biofísico, praticamente inalterados pela ocupação humana (Vilas Boas et al., 1986/88).

O Núcleo está localizado entre os paralelos $23^{\circ} 13^{\prime}$ e $23^{\circ} 16^{\prime}$ de latitude sul e os meridianos $45^{\circ} 02^{\prime}$ e $45^{\circ} 05^{\prime}$ de longitude oeste, distando cerca de $170 \mathrm{~km}$ da cidade de São Paulo e $15 \mathrm{~km}$ do Oceano Atlântico Encontrando-se eqüidistante dos dois maiores centros urbanos do pais (São Paulo e Rio de Janeiro). Encontra-se a $1070 \mathrm{~m}$ de altitude, localizando-se na região das cabeceiras do rio Paraibuna e na margem direita do rio Paraíba. Abrange uma parte do alto ao meio vale de Rio Paraibuna, pertencente ao Planalto de Paraitinga, no Planalto Atlântico (Furian \& Pfeifer,1986) (Figura 1).

O clima da região do tipo $\mathrm{Cfb}$ de Köppen, temperado úmido com a temperatura do mês mais quente inferior a $22^{\circ} \mathrm{C}$ (Ranzini, 2002). A temperatura anual média é de $16,5^{\circ} \mathrm{C}$ A precipitação média anual na estação meteorológica é de $2391 \mathrm{~mm}$ e $71 \%$ da precipitação anual ocorre durante a estação chuvosa (Cicco \& Fujieda, 1992)

A estrutura geológica é constituída de rochas cristalinas, gnaisses e migmatitos e granitos do pre-cambriano de difícil decomposição e os solos da área, mapeados por Brasil (1960), predominam como Latossolos Vermelho-Amarelos fase rasa $(\mathrm{LVr})$. O solo é quimicamente pobre, ácido e relativamente raso, com textura grosseira e estrutura fraca, isto é, os grânulos formam uma massa homogênea com muita fraca coerência, que aliados à elevada porosidade, condiciona-lhe boa permeabilidade (Furian e Pfeifer, 1986). 
A área é recoberta por vegetação natural secundária de Mata Atlântica (resultado da exploração ocorrida há mais de 45 anos), nas porções mais elevadas estão presentes remanescentes da vegetação primária, classificada, conforme Leitão Filho (1982), como Floresta Latifoliada Perenifolia desenvolvida em altitudes superiores a $1000 \mathrm{~m}$, apresentando árvores das famílias das Mirtaceas, Proteaceas, Melastomataceas, Lauraceas, Malpighiaceas, Magnoliaceas e Compostas (Furian \& Pfeifer 1986; Vilas Boas et al. 1986/88; Arcova et al. 1998; Arcova \&Cicco, 1997/99;)

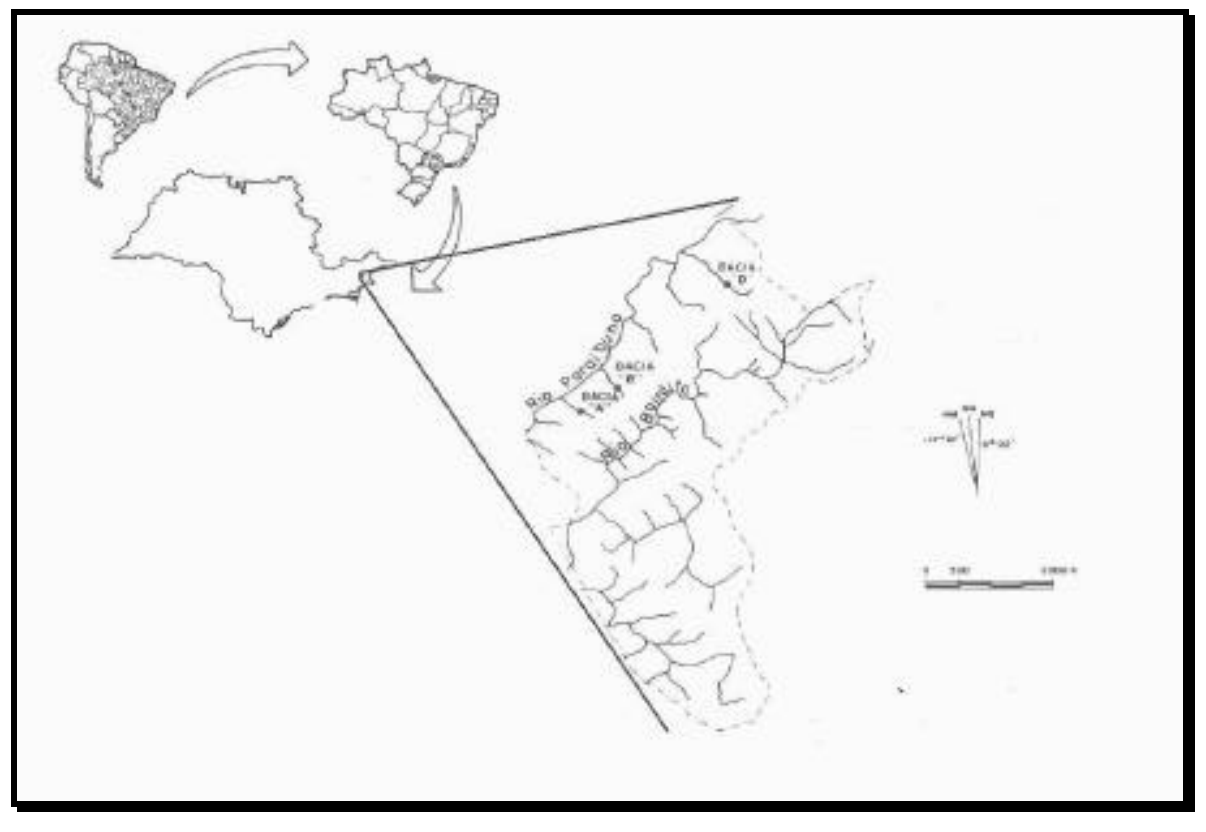

Figura 1 - Mapa de Localização da área experimental (Furian e Pfeiffer, 1986).

A área faz parte da bacia hidrográfica do rio Paraíba do Sul, que na sua parte mais elevada é formada pelas bacias hidrográficas dos rios Paraitinga e Paraibuna, totalizando $4400 \mathrm{~km}^{2}$. Dentro da área, três microbacias estão sendo monitoradas para o estudo das correlações entre a precipitação e o escoamento total (deflúvio). O mapa da rede de drenagem com todos os cursos de água permanente e a localização da microbacia A é apresentado na Figura 2 (Furian \& Pfeifer, 1986). A Figura 3, por outro lado apresenta a localização das três microbacias experimentais do Núcleo Cunha. 


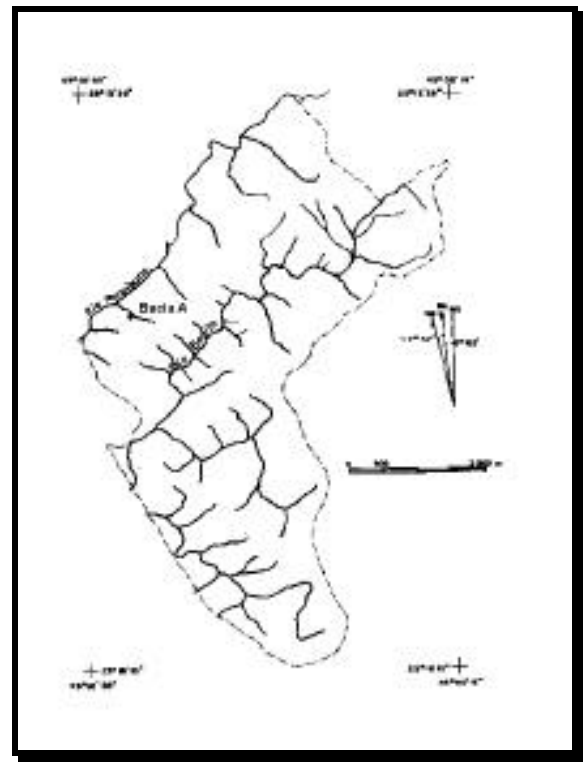

Figura 2 - Rede de drenagem da região do Núcleo Cunha (Furian e Pfeiffer, 1986).

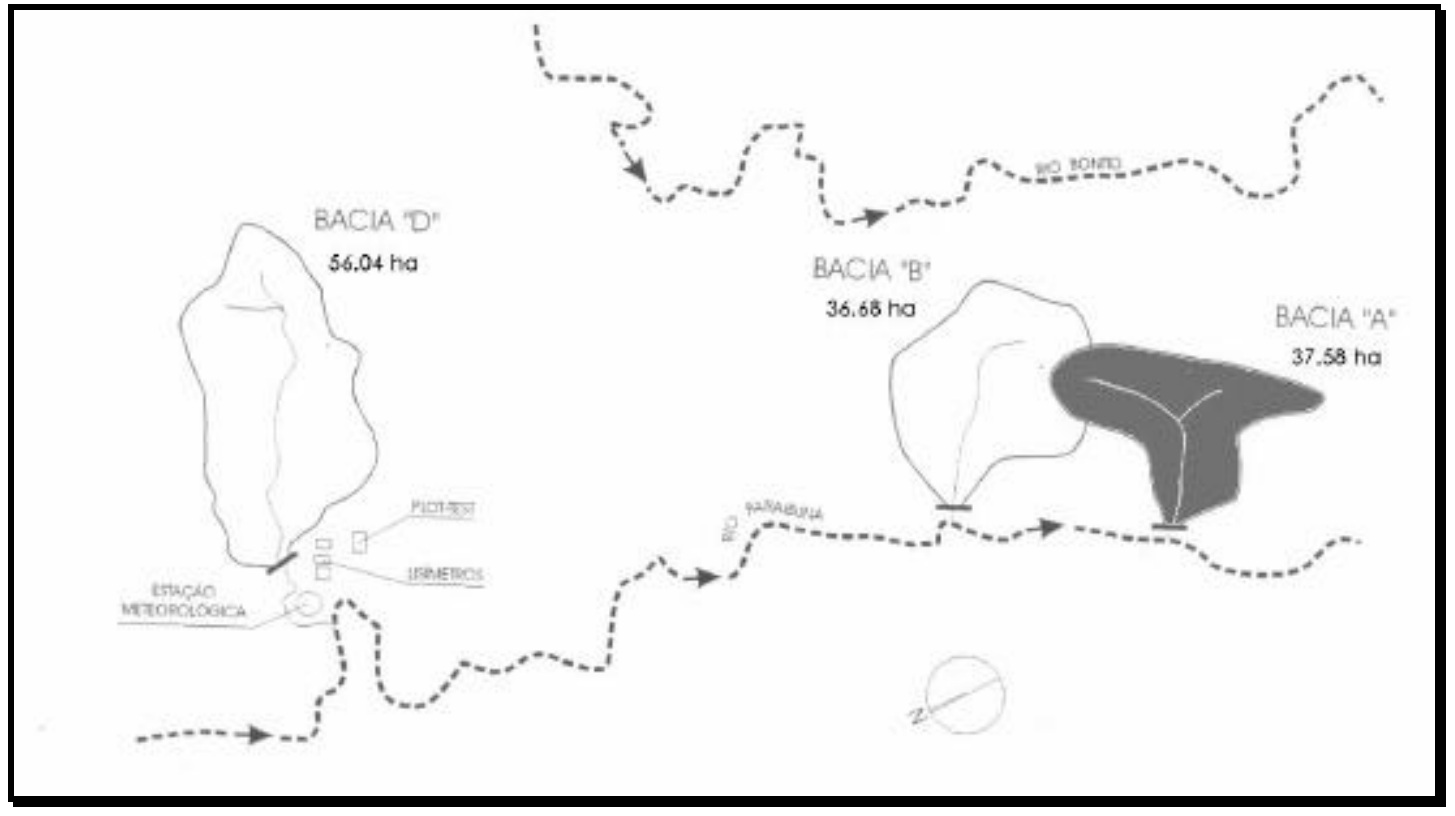

Figura 3 - Localização das microbacias experimentais que constituem o Laboratório de Hidrologia "Walter Emmerich" do Núcleo Cunha, ressaltando a microbacia A (Cicco \& Arcova, 1999) 


\subsection{Características da Microbacia Experimental}

A microbacia experimental A, cujos dados serão utilizados neste estudo, tem uma área de 37,58 ha, com uma variação de altitude de $1030 \mathrm{~m}$ até $1175 \mathrm{~m}$. O perímetro da microbacia é de $2800 \mathrm{~m}$, a largura média é de $350,5 \mathrm{~m}$ e o comprimento do canal principal é de 1070 m. A Figura 4 apresenta a microbacia A do Núcleo Cunha, destacando-se as principais curvas de nível e a localização do vertedor.

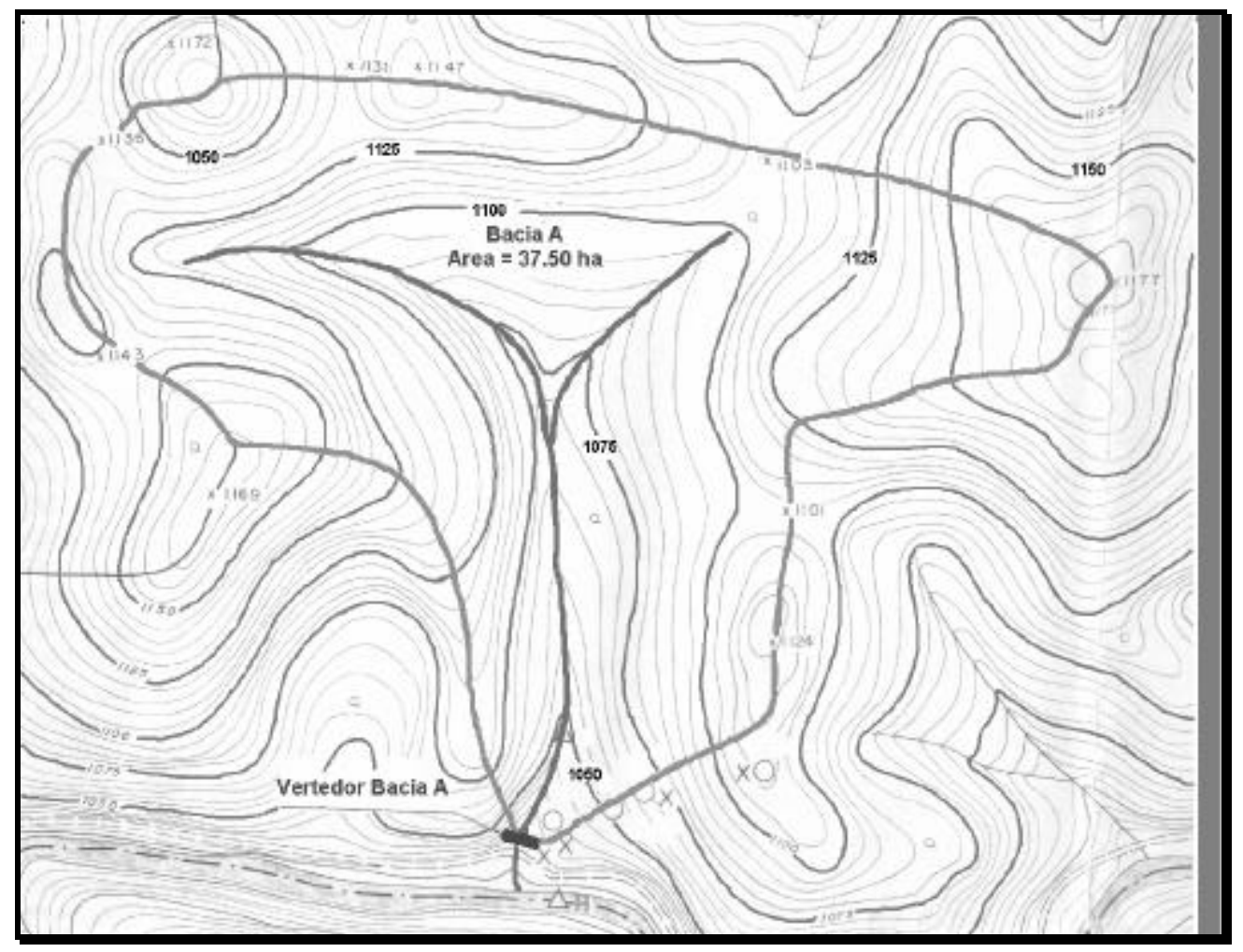

Figura 4 - Mapa da microbacia A destacando-se os cursos de água, as principais curvas de nível e a localização do vertedor. (Extraído de Compartment Map for experimental watershed JICA-IF E:1/5000)

A microbacia A está sendo monitorada desde fevereiro de 1992. Possui dois pluviógrafos de marca "NAKAASA" modelo W 11-00-60, de precisão igual a 0,5 mm, e está equipada com uma estação fluviométrica constituída de um tanque de sedimentação e um vertedor triangular de ferro de $5 \mathrm{~m}$ de largura, $1,5 \mathrm{~m}$ de altura e um ângulo de 
abertura de $120^{\circ}$, acoplado ao linígrafo tipo flutuador, de precisão igual a $0,5 \mathrm{~cm}$, o qual registra as variações da altura da lâmina de água no vertedor.

Como parte das pesquisas desenvolvidas pelo Instituto Florestal na área, o presente trabalho centra-se no estudo hidrológico da microbacia A. Para o estudo da caracterização hidrológica do presente projeto de dissertação foram utilizados os dados de:

- precipitação

- precipitação oculta

- vazão

- parâmetros físicos de qualidade de água turbidez e cor aparente.

- $\quad$ sedimentos totais em suspensão fixos e voláteis.

Além dos dados já acumulados ao longo do período 1992-1999, para este trabalho foram ainda efetuadas medições de vazão, precipitação, sedimentos em suspensão, turbidez e cor, relativas ao período de setembro de 2000 a abril de 2002, abrangendo dois períodos chuvosos. A precipitação oculta foi medida durante o período de abril de 2001 até abril 2002. As análises destes dados visam quantificar o comportamento hidrológico da microbacia.

\subsection{Balanço hídrico}

Os fluxos de entrada e saída de água nas microbacias são monitorados continuamente por intermédio de medições da precipitação com dois pluviógrafos tipo caçamba localizados um na estação fluviomêtrica e outro na parte superior da microbacia. As medições da cota fluviomêtrica são realizadas automaticamente com o linígrafo que se encontra na estação fluviométrica e acoplado ao vertedor. Este método permite a obtenção de um maior número de dados por estação fluviométrica e é muito útil para o desenvolvimento de pesquisas na área da hidrologia florestal. 


\subsubsection{Obtenção da curva chave Cota/Vazão}

A microbacia A foi monitorada em alguns eventos de chuvas ocurridos nos períodos chuvosos dos anos 1998 a 2001, amostrando-se 27 dados de cota fluviométrica e as respectivas velocidades médias, calculando-se a vazão através do método área por velocidade média da água naquela seção.

Para a determinação da vazão, considerou-se o volume de água escoada no tempo como sendo o produto da área ocupada pela lâmina d'água pela sua velocidade média, expressa através da equação (2):

$$
\mathrm{Q}=\mathrm{A} . \mathrm{V} .0,001
$$

onde,

$$
\begin{aligned}
& \mathrm{Q}=\text { vazão }\left(1 \mathrm{~s}^{-1}\right) ; \\
& \mathrm{A}=\text { área molhada }\left(\mathrm{cm}^{2}\right) ; \\
& \mathrm{V}=\text { velocidade média }\left(\mathrm{cm} \mathrm{s}^{-1}\right) .
\end{aligned}
$$

A velocidade da água foi determinada através de um molinete tipo Price, modelo KENEK, de fabricação japonesa. O equipamento possui uma pequena hélice móvel que gira em contato com o fluxo da água, sendo a velocidade expressa diretamente. As medições de velocidade foram feitas em várias profundidades e distribuídas na área da seção determinada pelo nível da água (Figura 5), a fim de se conseguir uma maior rede de pontos visando uma precisão detalhada na determinação da velocidade média da seção 


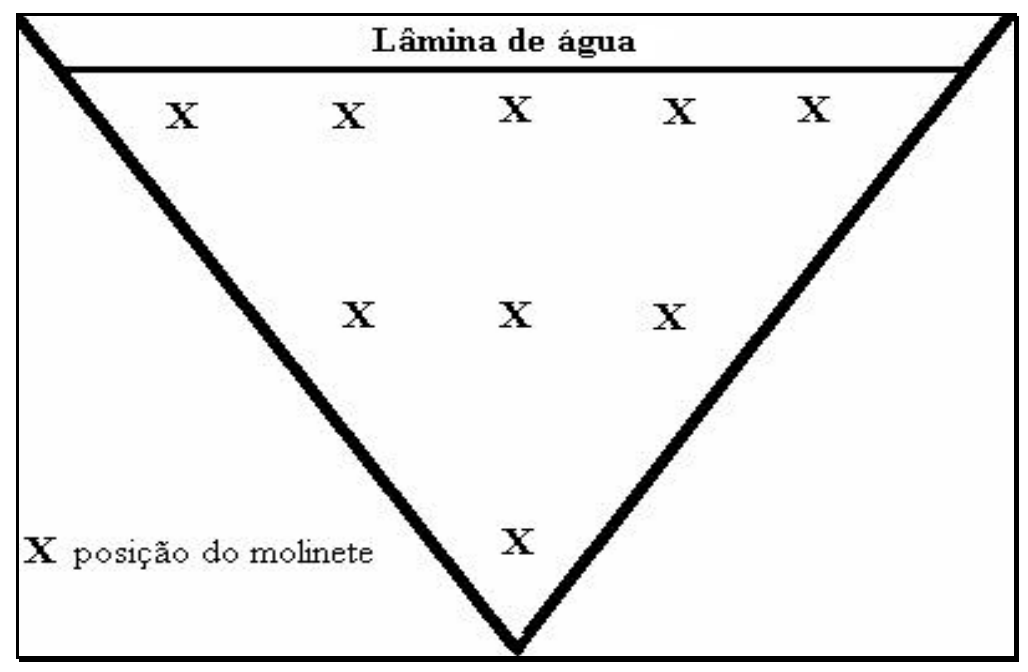

Figura 5 - Pontos da amostragem da velocidade do fluxo da água no vertedor

Foi estimada a curva chave (ou de calibragem) do vertedor não-padronizado da microbacia experimental A. Para isso foi utilizada análise de regressão linear onde os parâmetros da equação foram estimados pelo critério dos quadrados mínimos, obtendose a seguinte equação da curva chave a qual foi utilizada para o cálculo das descargas instantâneas e posterior cálculo do deflúvio:

$$
\mathrm{Q}=0,0561 \mathrm{H}^{2, .3778}
$$

Onde:

$$
\begin{aligned}
& \mathrm{Q}=\text { Vazão }\left(1 \mathrm{~s}^{-1}\right) \\
& \mathrm{H}=\text { Cota fluviométrica }(\mathrm{cm})
\end{aligned}
$$

\subsubsection{Balanço hídrico anual}

Levando em conta a equação hidrológica fundamental, e que a avaliação da evapotranspiração de uma bacia hidrográfica pode ser calculada pelo déficit de escoamento (Righetto,1998; Sousa Pinto et al.,1973), considerando-se a hipótese de que a microbacia não apresenta vazamentos através do substrato rochoso e que não estão ocorrendo fluxos laterais de água para fora ou para dentro da microbacia, o balanço hídrico pode ser determinado da seguinte forma: 
$\mathrm{P}=\mathrm{Q}+\mathrm{ET} \pm \mathrm{S}$

onde:

$$
\begin{aligned}
& \mathrm{P}=\text { precipitação total }(\mathrm{mm}) ; \\
& \mathrm{Q}=\text { deflúvio }(\mathrm{mm}) ; \\
& \mathrm{ET}=\text { evapotranspiração }(\mathrm{mm}) ; \\
& \mathrm{S}=\text { variação de armazenamento da água no solo }(\mathrm{mm}) .
\end{aligned}
$$

Este tipo de balanço é simplista ao considerar-se todos os processos que envolvem o escoamento na bacia, mas para intervalos de tempo suficientemente grandes o erro cometido no armazenamento e na propagação do escoamento é pequeno comparado com a precipitação, vazão e evapotranspiração, pelo que pode ser utilizado para a quantificação da evapotranspiração de uma microbacia (Tucci, 2000).

Como o balanço hídrico considera ciclos anuais nos quais o armazenamento de água no solo, em termos médios anuais, estaria equilibrado, tem-se então que este componente poderia ser considerado desprezível nos cálculos, razão pela qual a avaliação final do balanço hídrico pode ser feita segundo a seguinte equação simplificada:

$$
\mathrm{ET}=\mathrm{P}-\mathrm{Q}
$$

Para o cálculo dos balanços hídricos anuais, foram considerados os dados de pluviometria e vazão desde outubro de 1992 até setembro de 1999, e outubro de 2000 até setembro de 2001. O preenchimento de falhas diárias na pluviometria foi realizado pelo método da média aritmética entre os pluviógrafos instalados na microbacia A e, na microbacia B, que é adjacente, admitindo que todos os pluviógrafos tem o mesmo fator de ponderação. O preenchimento de falhas de vazão foi realizado seguindo dois critérios básicos: a) no caso de ausência de precipitação no dia, conservou-se a cota anterior e posterior à falha; b) no caso de ter havido precipitação no dia, o preenchimento das falhas foi feito pela média dos dias com leitura efetiva do respectivo mês. Este critério foi adotado para evitar diferenças ao se adotar a média do mês dos anos anteriores, já 
que, as vezes, as precipitações totais mensais entre um ano e outro podem ter variações grandes e a vazão média diária diferir bastante daquela do mês tratado.

Com base nas vazões calculadas pela curva-chave do vertedor, foram calculados os deflúvios mensais considerando-se a área da microbacia. A partir das precipitações e dos deflúvios mensais, foi calculado o déficit de escoamento e determinada a evapotranspiração anual considerando-se o ano hídrico adotado para Cunha que vai de outubro a setembro (Cicco et al., 1984).

\subsubsection{Precipitação oculta}

$\mathrm{Na}$ tentativa de conseguir determinar o acréscimo na entrada de água produzida pela captação de neblinas pelo dossel florestal, durante o período de 14 de novembro de 2000 até 18 de abril 2001, foram coletadas amostras semanais capturadas com coletores circulares colocados ao lado de pluviômetros (que permitem comparar as coletas realizadas em um e outro aparelho). Os coletores foram colocados, um perto do vertedor da microbacia A, e um outro na estação meteorológica do Núcleo Cunha. Estes coletores têm forma cilíndrica e foram construídos com tecido de polipropileno, "ráfia", com peso especifico de $126 \mathrm{~g} \mathrm{~m}^{-2}$, com um percentual de cobertura de 52 a $60 \%$, e resistência a radiação UV, segundo as descrição técnica do fabricante: ERNETEX Ind. e Com. Ltda. As dimensões dos coletores são de 39,8 cm de altura e 19,5 cm de diâmetro, e encontram-se montados sobre a base de um pluviômetro (Figura 6).

Inicialmente, pretendia-se transformar a medida de água coletada em "mm” de precipitação com base na área de captação da tela de nylon, descontando-se os valores de precipitação convencional medida na área. Todavia, encontraram-se dificuldades nesta avaliação, devido à ocorrência de perdas nos procedimentos de coletas semanais, que não puderam ser quantificadas, tornando os resultados obtidos não consistentes. 


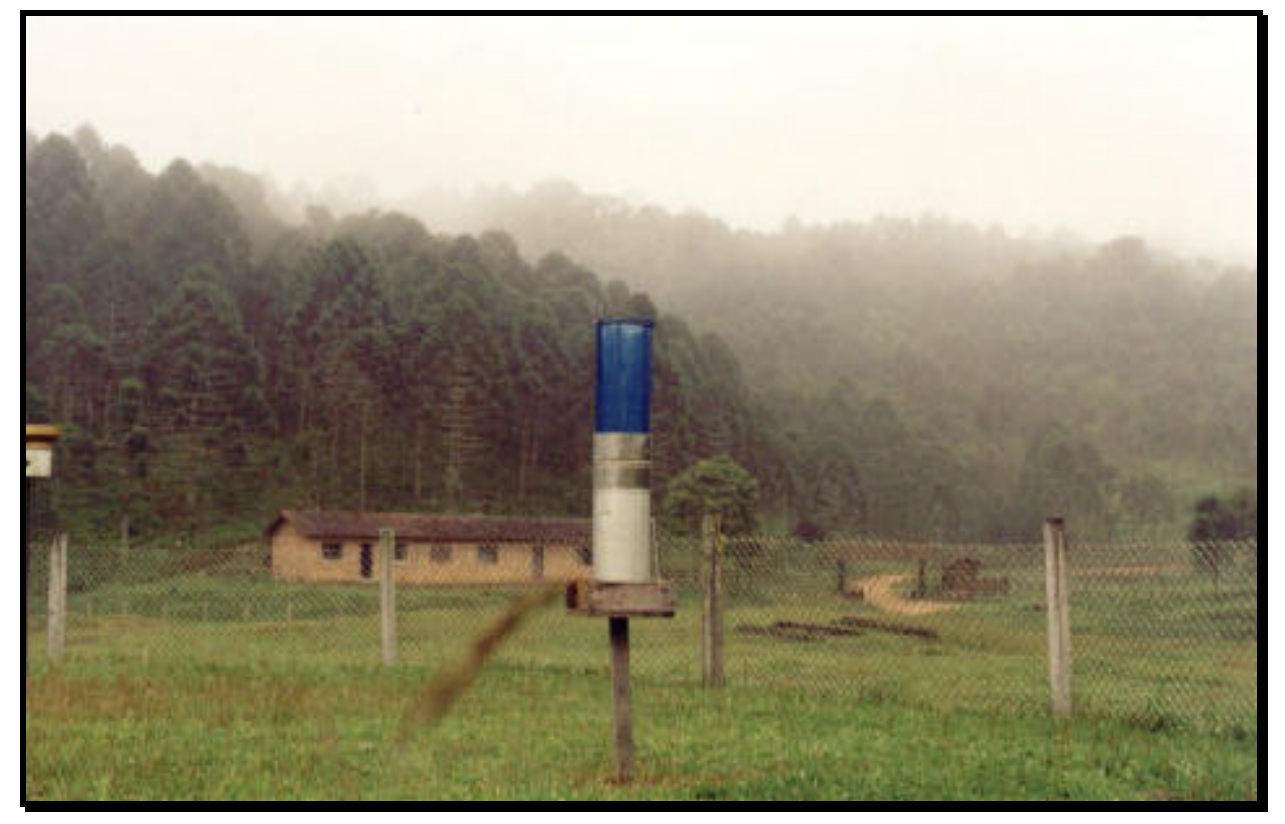

Figura 6 - Coletor de neblinas localizado na estação meteorológica do Núcleo Cunha.

Pelos motivos expostos, a partir de 18 de abril de 2001 decidiu-se fazer coletas diárias no posto meteorológico, que se prolongaram pelo período de um ano, para conseguir separar melhor os eventos de neblinas dos de chuvas, ao comparar os resultados do coletor com os do pluviômetro e do pluviógrafo.

Para os cálculos, foi considerado em primeiro lugar o período seco do ano, desde abril até finais de agosto. Considerou-se evento de neblina aquele onde não se registraram marcas superiores a 3,5 mm no pluviógrafo (tendo em conta que sob esta poderia corresponder a chuvas finas misturadas com neblinas, fenômeno que pode ser observado na região) da análise dos dados correspondentes a 52 dias do período.

Alem destes dados, foram também considerados todos os eventos de condensação e neblinas acontecidos no ano de medições, correspondendo a 87 eventos. Finalmente, foi considerada a totalidade dos dados.

Calcularam-se as diferenças dos volumes de água do coletor de neblinas e do pluviômetro. Em seguida, calculou-se a equivalência em milímetros de precipitação 
desse volume, segundo à superfície de captura do coletor (considerada de $50 \%$ da superfície total do cilindro correspondente), mediante a seguinte fórmula:

Superfície de coleta $=2 \pi \mathrm{r}$ h 0,5

onde,

$\mathrm{r}=$ raio do cilindro do coletor $(\mathrm{cm})$;

$\mathrm{h}=$ altura do cilindro $(\mathrm{cm})$.

Da mesma forma, foram feitos cálculos para obter as diferenças de volume de água coletada no coletor de neblinas e no pluviógrafo, fazendo primeiramente a conversão volumétrica da altura de água coletada no pluviógrafo. Estes resultados foram comparados com os milímetros de precipitação coletados no pluviômetro e no pluviógrafo, depois calculados os percentuais de incremento correspondentes.

\subsection{Qualidade da água}

\subsubsection{Caracterização da qualidade da água do deflúvio}

Foram coletadas amostras semanais da água do riacho em garrafas de polietileno de $1000 \mathrm{ml}$, bem como amostras da água do escoamento direto, através de um sistema de 4 garrafas de polietileno de $600 \mathrm{ml}$, instaladas em duas linhas paralelas, cada uma a $30 \mathrm{~cm}$ ao longo da altura do vertedor (Figura 7). A coleta das amostras foi realizada no período de setembro de 2000 até abril de 2002.

Sem proceder à filtragem das amostras, foram analisados os parâmetros físicos turbidez e cor aparente. As análises foram feitas com espectrofotômetro, utilizando-se comprimento de onda de 400 e $455 \eta \eta \mathrm{m}$, respectivamente, para cada um dos parâmetros estudados. O método baseia-se na comparação da transmissão da luz na amostra com a transmissão da luz em uma amostra de água destilada. 


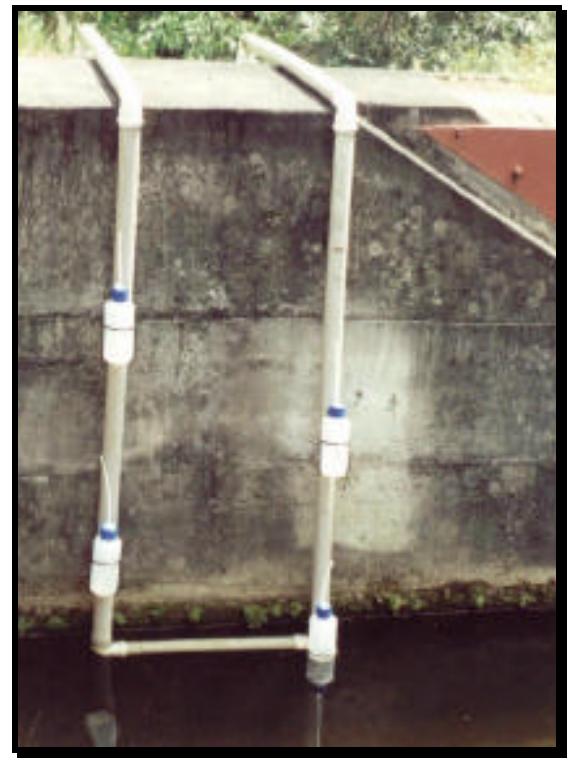

Figura 7 - Sistema de coletas de amostras em duas linhas paralelas.

Foi analisado o comportamento da turbidez e da cor aparente em função do tempo e do regime de precipitações, encontrando-se as correlações correspondentes e a relação entre as duas variáveis.

\subsubsection{Quantificação das perdas médias de sedimentos em suspensão na água do deflúvio}

Os sedimentos totais em suspensão das amostras, assim como suas frações de sedimentos voláteis e fixos, foram analisados por filtragem, com filtro de fibra de vidro marca "Whatmann" GF/B, de porosidade igual a $0,1 \mu$, de uma alíquota de $250 \mathrm{ml}$. As amostras foram filtradas com bomba de vácuo e secadas em estufa a $103{ }^{\circ} \mathrm{C}$. Da pesagem em balança de precisão obtém-se a concentração de sedimentos totais em suspensão. A separação da frações volátil e fixa (considerada orgânica e inorgânica, respectivamente, em um afã de simplificar os conceitos) foi realizada por calcinação do material em mufla a $550{ }^{\circ} \mathrm{C}$ durante 15 minutos e posterior pesagem em balança de precisão, após a estabilização de peso e temperatura. 
Os cálculos de sedimentos totais e suas frações fixas e voláteis foram feitos pelas diferenças de peso entre os sedimentos totais e fixos, expressos em mg $1^{1}$. Estes foram correlacionados com as características das precipitações e do deflúvio.

A densidade de fluxo de sedimentos, ou seja, a perda de sedimentos da microbacia em $\mathrm{kg} \mathrm{ha}^{-1} \mathrm{ano}^{-1}$, pode então ser obtida pelo produto da concentração de sedimentos pelo deflúvio. 


\section{RESULTADOS E DISCUSSÃO:}

\subsection{Balanço hídrico}

\subsubsection{Obtenção da curva chave Cota-Vazão}

A determinação da curva chave é necessária para vertedores não padronizados, tendo em vista que a construção dos mesmos nem sempre atende perfeitamente às normas e especificações. Correlacionando os valores de vazão em função dos valores da cota fluviométrica, obtêm-se a equação da relação cota-vazão, a qual permite descartar as influências que poderiam estar relacionadas à construção do vertedor.

A curva chave achada é expressa na equação (7), existindo uma relação linear, com um elevado coeficiente de determinação, ${ }^{2}=0,9872$ que estaria indicando que ao introduzir o uso da variável altura da lamina da água, 98\% das variações dos valores de vazão estaria explicada pelo modelo adotado. O coeficiente de correlação $r=0,9936$ estaria indicando uma alta correlação positiva entre as variáveis.

$$
\mathrm{Q}=0,0561 \mathrm{H}^{2,3778}
$$

Com a transformação logarítmica dos dados consegue-se que o modelo de regressão linear se torne adequado (Figura 8). A curva chave obtida permite determinar as vazões simplesmente pelo monitoramento automático e contínuo do nível da água, através do linígrafo. 


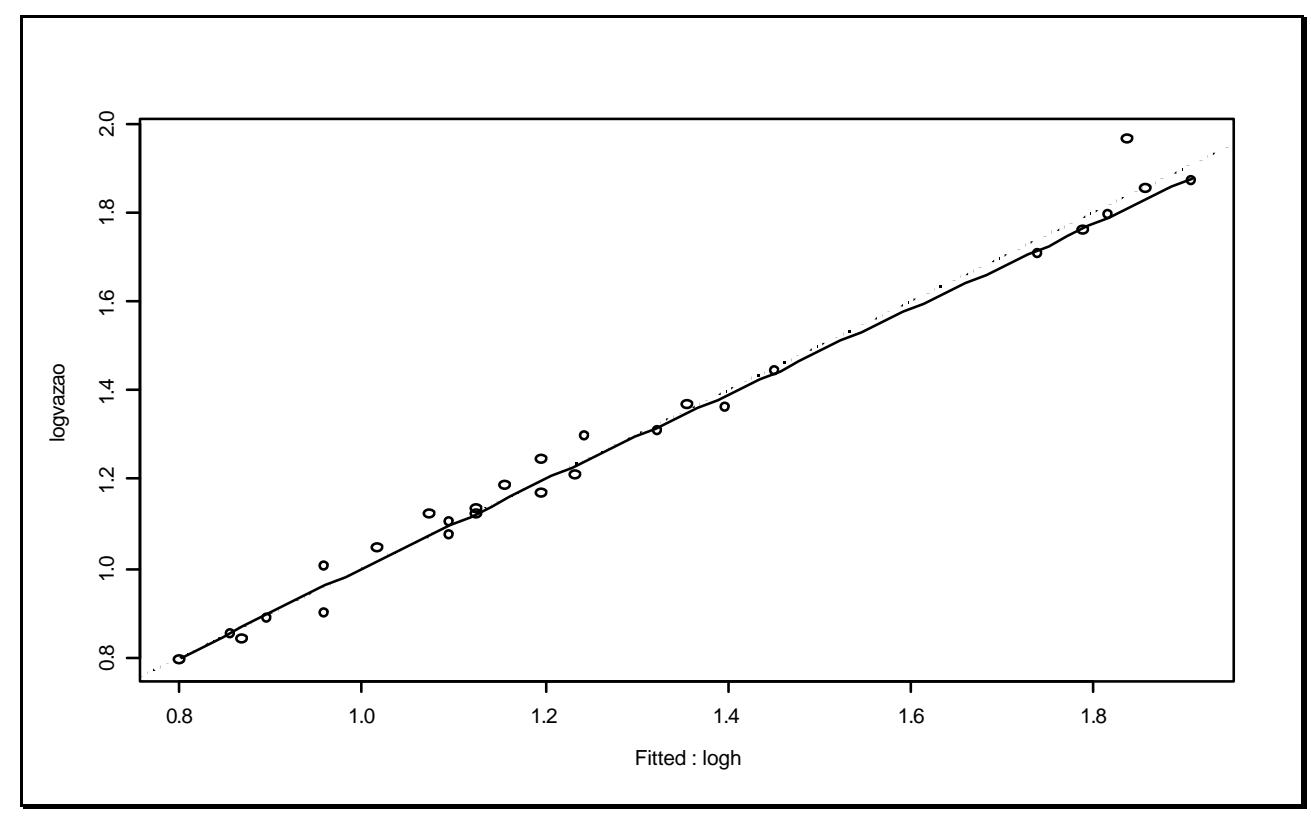

Figura 8 - Representação logarítmica do modelo de regressão linear que relaciona a cota fluviométrica com a vazão. logh: logaritmo decimal da cota fluviométrica, logvazao: logaritmo decimal da vazão.

A Tabela 1 apresenta os resultados das vazões determinadas em campo. Os dados de altura da lâmina de água amostrados variaram de 7,3 cm à $21,3 \mathrm{~cm}$ a as respectivas vazões variaram de $6,236 \mathrm{l} \mathrm{s}^{-1}$ a 74,085 $1 \mathrm{~s}^{-1}$. Consequentemente, a velocidade média da água não foi determinada para valores superiores a $21,3 \mathrm{~cm}$, devido principalmente a ausência de chuvas durante as viagens de trabalho de campo.

Cabe ressaltar que as cotas fluviométricas medidas se correspondem com as cotas que encontram-se na faixa predominante na microbacia A. Arcova (1996) demonstra, através das curvas de duração do fluxo diário das microbacias experimentais B e D, que $80 \%$ do tempo o deflúvio diário foi inferior a $6,0 \mathrm{~mm}$, representado principalmente pelo escoamento base. $\mathrm{Na}$ microbacia $\mathrm{A}$, os deflúvios médios diários também seguem este padrão, sendo que só no mês de fevereiro o deflúvio médio diário supera esse valor, sendo de $6,1 \mathrm{~mm} \mathrm{dia}^{-1}$, este valor corresponde a uma cota inferior a $13,7 \mathrm{~cm}$. 
Tabela 1. Valores de altura da lâmina de água, área da seção molhada, velocidade média da água e vazões calculadas em campo

\begin{tabular}{|c|c|c|c|c|c|c|}
\hline Medição & Data & Cota $(\mathrm{cm})$ & $\begin{array}{l}\text { Área molhada } \\
\left(\mathrm{cm}^{2}\right)\end{array}$ & $\begin{array}{l}\text { Vel.média } \\
\left(\mathrm{cm} \mathrm{s}^{-1}\right)\end{array}$ & $\begin{array}{l}\text { Vazão } \\
\left(1 \mathrm{~s}^{-1}\right)\end{array}$ & $\begin{array}{c}\text { Deflúvio } \\
\left(\mathrm{mm} \mathrm{dia}^{-1}\right)\end{array}$ \\
\hline 1 & $20 / 08 / 98$ & 7,30 & 92,30 & 67,56 & 6,24 & 1,43 \\
\hline 2 & $17 / 09 / 98$ & 7,70 & 102,69 & 68,97 & 7,10 & 1,63 \\
\hline 3 & 18/09/98 & 7,80 & 105,38 & 65,94 & 6,90 & 1,59 \\
\hline 4 & 17/09/98 & 8,00 & 110,85 & 69,63 & 7,72 & 1,77 \\
\hline 5 & $22 / 10 / 98$ & 8,50 & 125,14 & 63,17 & 7,90 & 1,82 \\
\hline 6 & $19 / 09 / 00$ & 8,50 & 125,10 & 80,69 & 10,09 & 2,32 \\
\hline 7 & 09/02/01 & 9,00 & 140,00 & 79,13 & 11,08 & 2,55 \\
\hline 8 & 08/02/01 & 9,50 & 156,30 & 84,71 & 13,24 & 3,04 \\
\hline 9 & $04 / 02 / 99$ & 9,70 & 162,96 & 72,70 & 11,80 & 2,71 \\
\hline 10 & $16 / 02 / 01$ & 9,70 & 162,78 & 77,85 & 12,67 & 2,91 \\
\hline 11 & $11 / 12 / 98$ & 10,00 & 173,20 & 78,60 & 13,60 & 3,13 \\
\hline 12 & $12 / 02 / 01$ & 10,00 & 173,00 & 75,81 & 13,12 & 3,02 \\
\hline 13 & $10 / 12 / 98$ & 10,30 & 183,75 & 83,40 & 15,30 & 3,52 \\
\hline 14 & 13/01/99 & 10,70 & 198,30 & 88,70 & 17,60 & 4,05 \\
\hline 15 & $14 / 01 / 99$ & 10,70 & 198,30 & 74,04 & 14,66 & 3,37 \\
\hline 16 & 15/01/99 & 11,10 & 213,40 & 76,00 & 16,20 & 3,72 \\
\hline 17 & $14 / 01 / 99$ & 11,20 & 217,27 & 91,17 & 19,80 & 4,55 \\
\hline 18 & $17 / 02 / 01$ & 12,10 & 253,29 & 80,45 & 20,38 & 4,69 \\
\hline 19 & $20 / 03 / 01$ & 12,50 & 270,31 & 85,48 & 23,11 & 5,31 \\
\hline 20 & $10 / 12 / 98$ & 13,00 & 292,72 & 88,78 & 23,00 & 5,29 \\
\hline 21 & $10 / 12 / 98$ & 13,70 & 325,09 & 84,80 & 27,60 & 6,35 \\
\hline 22 & $15 / 02 / 01$ & 18,10 & 566,77 & 90,09 & 51,06 & 11,74 \\
\hline 23 & $15 / 02 / 01$ & 19,00 & 624,53 & 91,90 & 57,39 & 13,19 \\
\hline 24 & 20/03/01 & 19,50 & 657,83 & 94,55 & 62,20 & 14,30 \\
\hline 25 & $10 / 12 / 98$ & 19,90 & 685,90 & 133,60 & 91,60 & 21,06 \\
\hline 26 & $20 / 03 / 01$ & 20,30 & 712,92 & 99,22 & 70,74 & 16,26 \\
\hline 27 & $15 / 02 / 01$ & 21,30 & 784,88 & 94,39 & 74,08 & 17,03 \\
\hline
\end{tabular}

O deflúvio médio diário foi de $3,5 \mathrm{~mm} \mathrm{dia}^{-1}$, e o valor de fluxo menor obtido pela medição direta correspondeu a $1,47 \mathrm{~mm} \mathrm{dia}^{-1}$, enquanto que o deflúvio diário médio 
mínimo foi de $1,79 \mathrm{~mm}$ no mês de agosto. Estes fatos indicariam que, ao utilizar a curva chave obtida, no caso de fazer alguma extrapolação para o cálculo do deflúvio, esta se faria somente na porção superior da curva.

\subsubsection{Balanço hídrico anual}

A média de precipitação obtida na área entre outubro de 1992 até setembro de 1999 foi de $1865 \mathrm{~mm}$ anuais. A precipitação total no ano 2000-2001 foi de $1605 \mathrm{~mm}$ o que representou uma diminuição de $14 \%$ na precipitação ao compará-la com a média considerada. Considerando a média dos 8 anos mencionados, a precipitação média na Bacia A foi de $1832 \mathrm{~mm}$ (Figura 9) com um desvio padrão igual a $319 \mathrm{~mm}$ e intervalo de confiança para $95 \%$ de probabilidade entre 2053 e $1610 \mathrm{~mm}$.

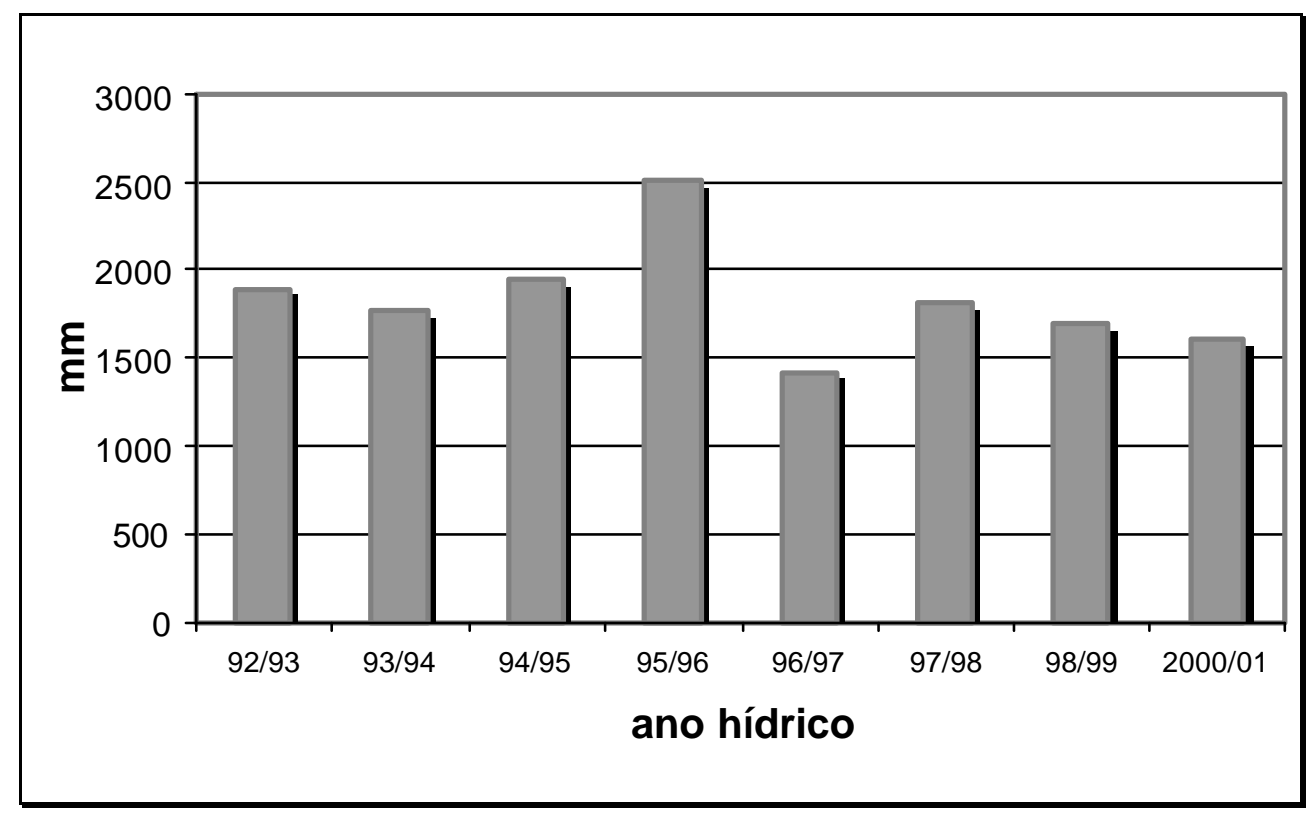

Figura 9 - Precipitação anual da microbacia A para os períodos outubro 92 a setembro 99 e outubro 2000 a setembro 2001.

A distribuição mensal das precipitações está ilustrada na Figura 10, observando-se uma clara diferença entre a estação úmida, entre os meses de setembro a março, e a estação seca do ano, de abril a agosto. No período úmido, se produz, em 
média, 84\% das precipitações ocorridas durante o ano. Entre os meses de janeiro a março concentram-se as maiores precipitações com uma média máxima de $275 \mathrm{~mm}$ para o mês de fevereiro e una média mínima de $39 \mathrm{~mm}$ para os meses de julho e agosto.

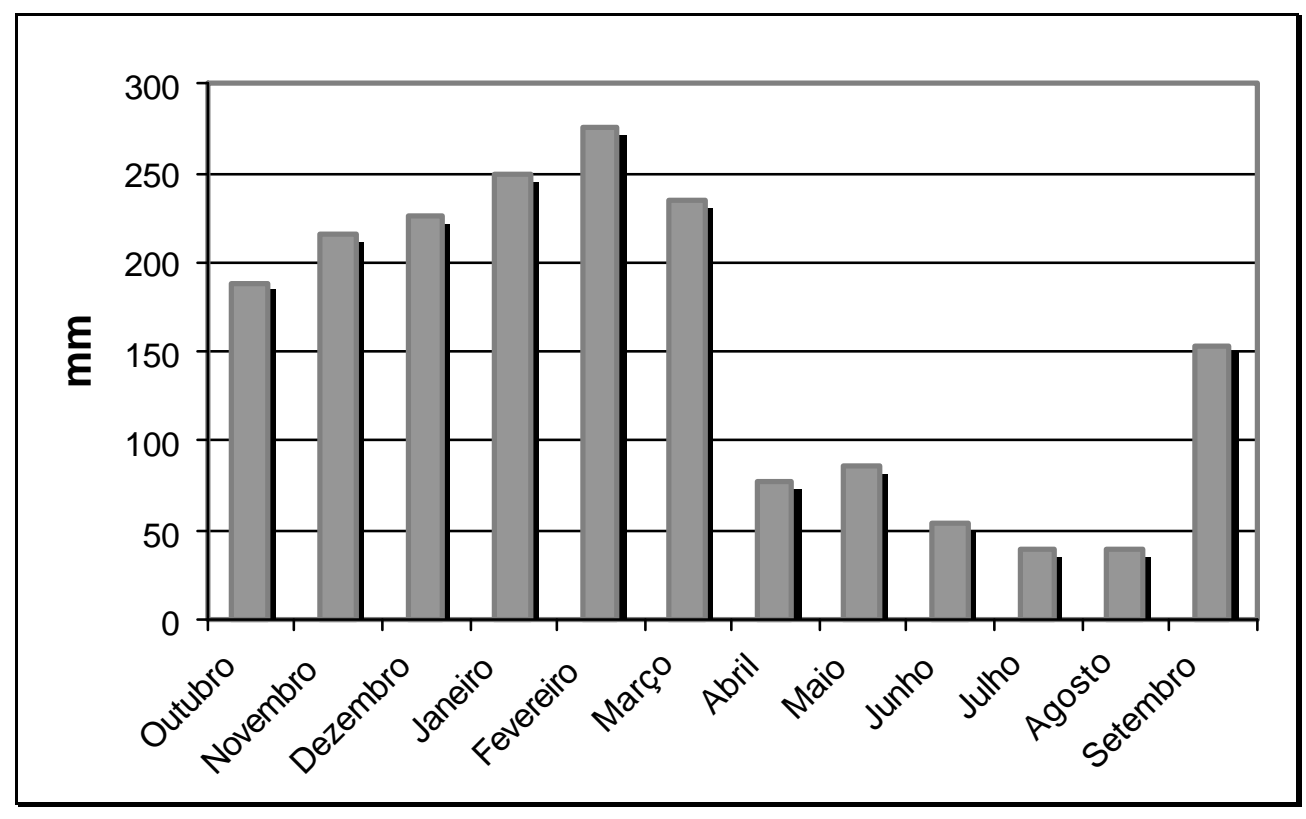

Figura 10 - Precipitação média mensal da microbacia A.

Foram calculados os deflúvios mensais e anuais dos anos analisados. Na Figura 11 observa-se os deflúvios anuais totais e pode-se notar que os anos de maior deflúvio correspondem com aqueles de maior precipitação ( Figura 9).

O deflúvio médio mensal máximo correspondeu ao mês de março, com uma grandeza de $183 \mathrm{~mm}$, enquanto que o deflúvio mensal médio mínimo produziu-se no mês de agosto, com 56 mm (Figura 12). O deflúvio anual médio foi de 1279 mm. 


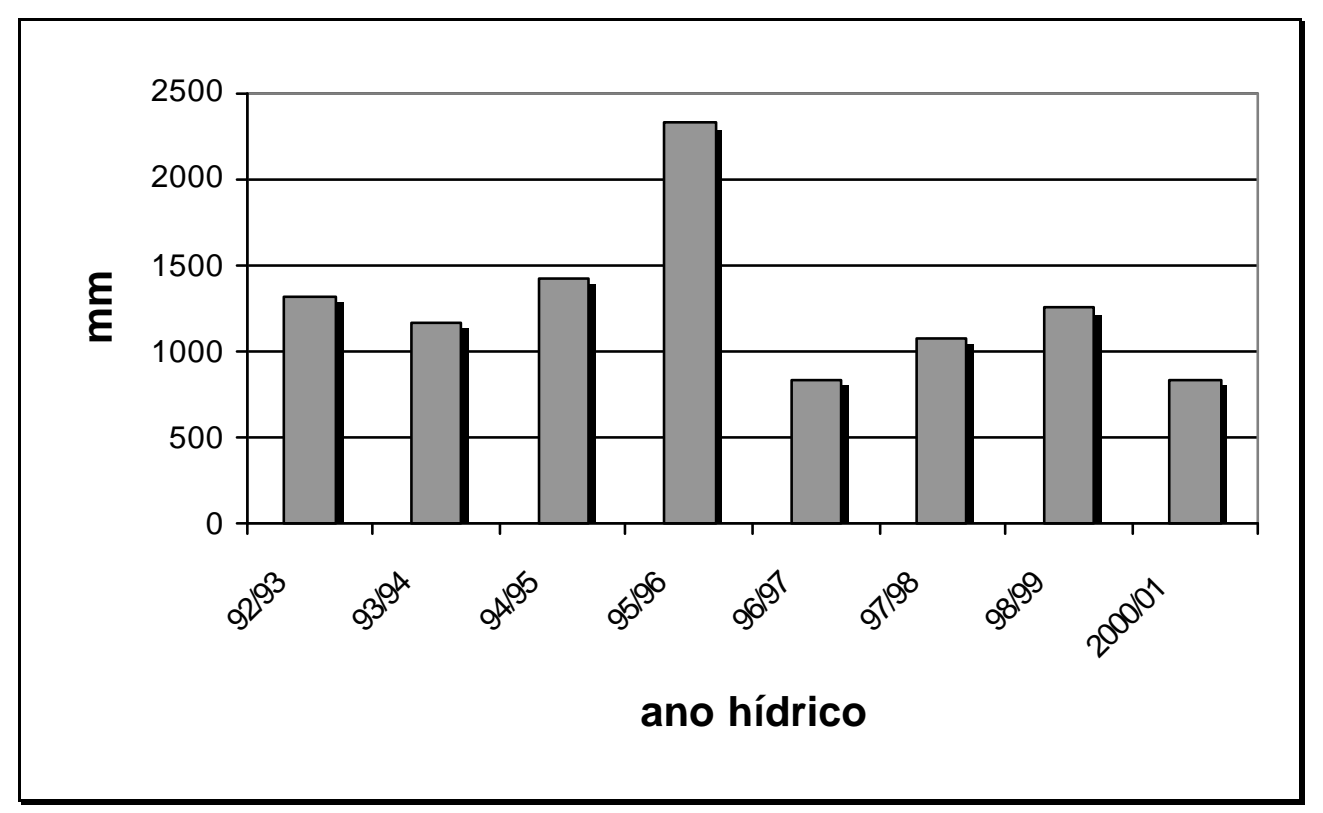

Figura 11 - Deflúvio anual da microbacia A para os períodos outubro 92 a setembro 99 e outubro 2000 a setembro 2001.

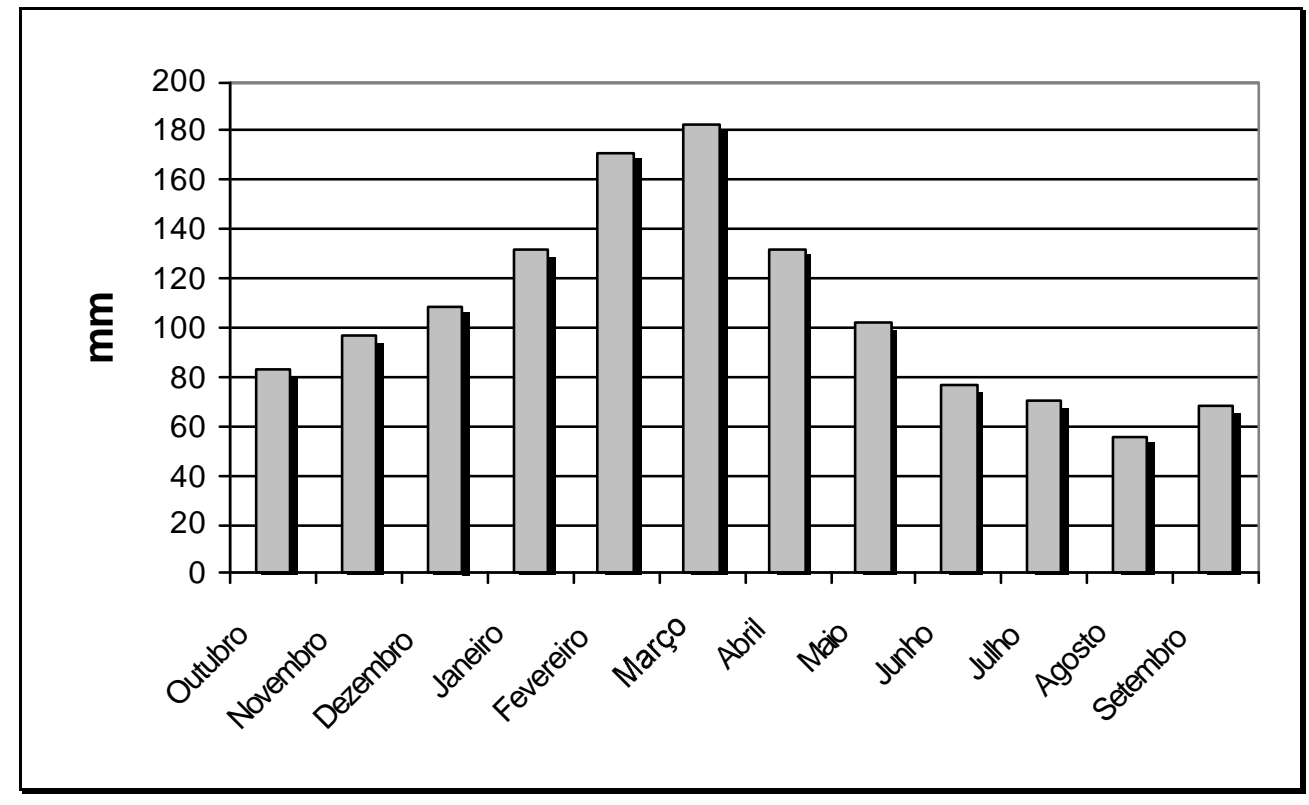

Figura 12 - Deflúvio médio mensal da microbacia A.

Ao observar-se a distribuição do deflúvio no ano, não se observa essa diferença acentuada entre período seco e úmido, como se vê na precipitação. Observa-se, 
no caso, um aumento paulatino dos escoamentos a partir do mês de setembro até março, correspondendo estes a $66 \%$ do escoamento total anual $(842 \mathrm{~mm})$ e uma diminuição gradual dos mesmos entre os meses de abril a agosto, representando 35\% do deflúvio anual $(436 \mathrm{~mm})$. Isto estaria indicando que as chuvas incidentes na área infiltrariam no solo escoando gradualmente ao longo do ano.

Fazendo o cálculo do déficit de escoamento pelo balanço de massas (precipitação menos deflúvio), obteve-se uma perda de $553 \mathrm{~mm}$ que corresponderiam as perdas ocasionadas pelo processo de evapotranspiração. Na Figura 13, pode-se observar o regime médio das chuvas e do deflúvio no ano, ressaltando-se os períodos de déficit e excesso do escoamento.

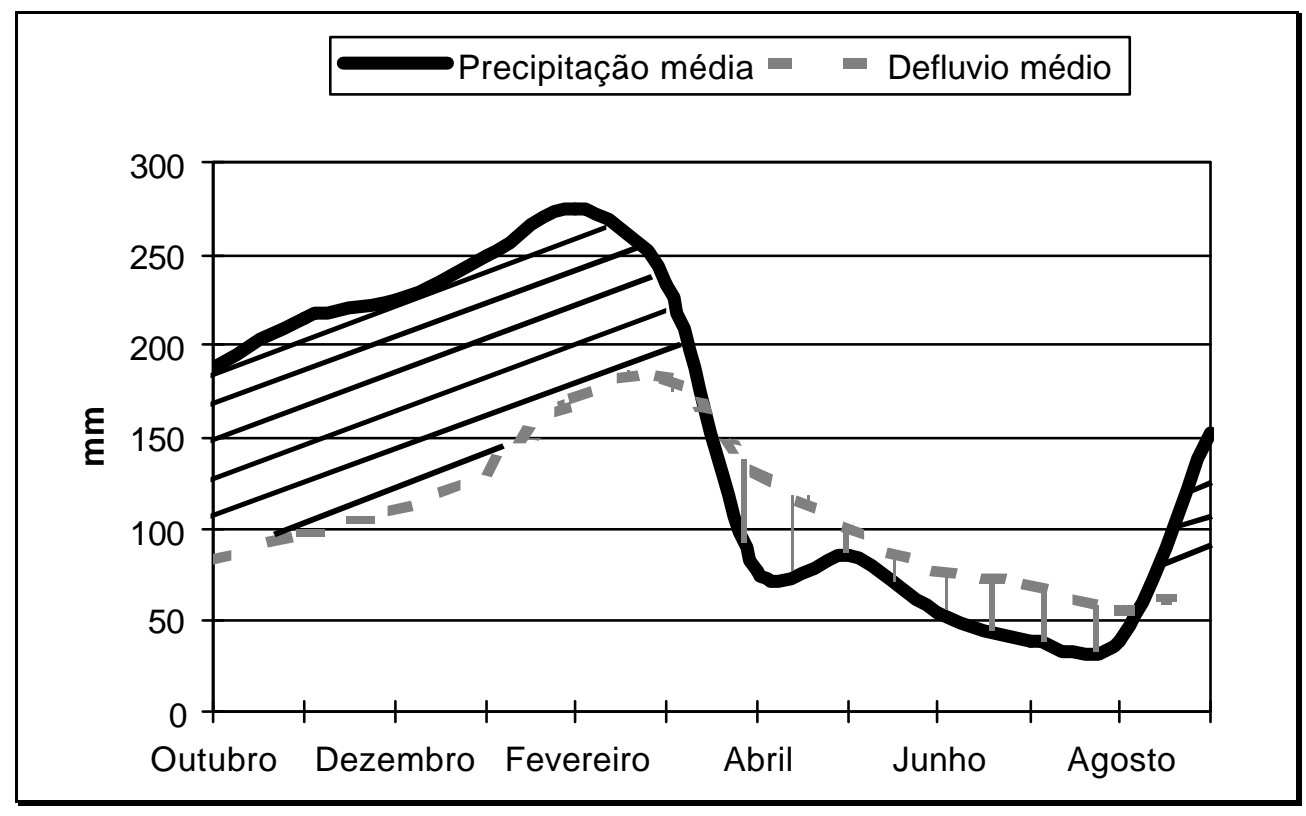

Figura 13 - Regime de precipitação e deflúvio médios mensais da microbacia A.

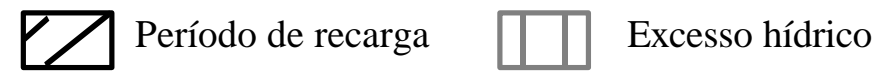

Dos resultados dos balanços hídricos anuais, observa-se na Figura 14 a variação da evapotranspiração nos diferentes anos relacionada com a pluviometria e o deflúvio dos mesmos. A máxima evapotranspiração foi observada no ano hídrico 2000- 
2001, sendo de $771 \mathrm{~mm}$, correspondendo a $48 \%$ da precipitação. Contudo, deve-se considerar que neste ano a precipitação foi de $1605 \mathrm{~mm}$, sendo $12 \%$ inferior à média anual. No ano hídrico 1995-1996 foi quando ocorreu a menor evapotranspiração, de 180 $\mathrm{mm}$, correspondendo a $7 \%$ da precipitação total. Neste ano a precipitação foi de 2505 mm, sendo $37 \%$ superior à média anual . Finalmente a evapotranspiração média da microbacia foi de $553 \mathrm{~mm}$ ao ano, o que corresponde ao $32 \%$ da precipitação convencional total.

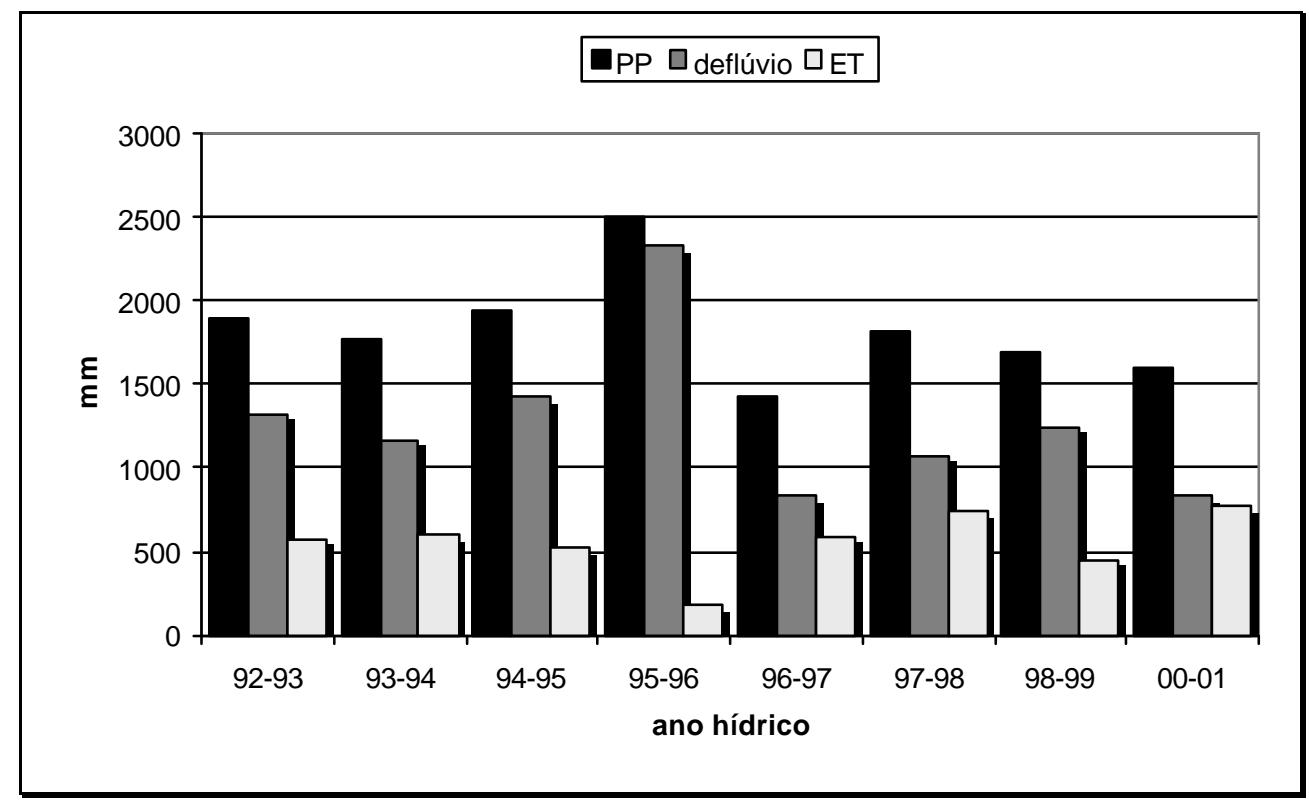

Figura 14 - Relação entre precipitação (PP), deflúvio e evapotranspiração (ET) da microbacia A para os anos hídricos do período experimental.

Ao comparar os dados obtidos pelo balanço de massa com o método de Thornthwaite \& Mather (1955) para o cálculo da evapotranspiração, obtiveram-se algumas diferenças observadas na Tabela 2 .

Pode-se observar que os resultados obtidos segundo os métodos diferem em suas grandezas. O balanço de Thornthwaite determina uma evapotranspiração maior de aquela obtida pelo método do balanço de massas, correspondendo essa diferença a 207 mm, o que indicaria que a evapotranspiração estimada pelo método de Thornthwaite 
superaria em $37 \%$ à calculada pelo balanço de massas. Este fato poderiam estar relacionado com a ata umidade relativa do ambiente, e reforçaria a expectativa de estar havendo um ingresso adicional de água devido à precipitação oculta.

Tabela 2. Estimativa da evapotranspiração (ET) segundo o método de Thornthwaite e Matter (1955) e pelo balanço de massa. ETP: evapotranspiração potencial; ETR: evapotranspiração real; ARM: armazenamento de água no solo; DEF: deficiências hídricas; EXC: excessos hídricos; ET: evapotranspiração; P: precipitação média mensal; Q: deflúvio médio mensal.

\begin{tabular}{|c|c|c|c|c|c|c|}
\hline \multirow[b]{2}{*}{ Meses } & \multicolumn{4}{|c|}{ Thornthwaite } & & \multirow{2}{*}{$\begin{array}{c}\text { Balanço de } \\
\text { Massa } \\
(\mathrm{ET}=\mathrm{P}-\mathrm{Q}) \\
\mathrm{mm}\end{array}$} \\
\hline & $\begin{array}{c}\text { ETP } \\
\mathrm{mm}\end{array}$ & $\begin{array}{c}\text { ETR } \\
\text { mm }\end{array}$ & $\begin{array}{c}\text { ARM } \\
\mathrm{mm}\end{array}$ & $\begin{array}{c}\mathrm{DEF} \\
\mathrm{mm}\end{array}$ & $\begin{array}{c}\mathrm{EXC} \\
\mathrm{mm}\end{array}$ & \\
\hline Janeiro & 95,02 & 95,0 & 100,00 & 0,0 & 153,7 & 117,24 \\
\hline Fevereiro & 87,91 & 87,9 & 100,00 & 0,0 & 187,3 & 104,08 \\
\hline Março & 85,04 & 85,0 & 100,00 & 0,0 & 148,8 & 51,16 \\
\hline Abril & 63,79 & 63,8 & 100,00 & 0,0 & 12,7 & $-55,70$ \\
\hline Maio & 45,17 & 45,2 & 100,00 & 0,0 & 39,9 & $-16,94$ \\
\hline Junho & 36,38 & 36,4 & 100,00 & 0,0 & 17,4 & $-22,89$ \\
\hline Julho & 35,76 & 35,8 & 100,00 & 0,0 & 3,1 & $-31,22$ \\
\hline Agosto & 41,84 & 41,8 & 96,98 & 0,0 & 0,0 & $-16,86$ \\
\hline Setembro & 52,06 & 52,1 & 100,00 & 0,0 & 97,9 & 84,67 \\
\hline Outubro & 63,20 & 63,2 & 100,00 & 0,0 & 124,8 & 105,33 \\
\hline Novembro & 66,23 & 66,2 & 100,00 & 0,0 & 149,0 & 118,38 \\
\hline Dezembro & 88,41 & 88,4 & 100,00 & 0,0 & 136,7 & 116,15 \\
\hline TOTAL & 760,80 & 760,8 & 1197,00 & 0,0 & 1071,3 & 553,39 \\
\hline
\end{tabular}

Foram analisados alguns hidrogramas correspondentes a eventos de chuvas entre outubro de 2000 e abril de 2002 que superaram a cota de $19 \mathrm{~cm}$ (Tabela 3). 
Tabela 3. Resumo do análise dos hidrogramas de eventos de chuva ocorridos no período outubro-2000 a abril-2002. $\mathrm{I}_{\max }$ : Intensidade máxima de precipitação; $\mathrm{E}_{\mathrm{T}}$ Escoamento total; $\mathrm{E}_{\mathrm{B}}$ : Escoamento base; $\mathrm{E}_{\mathrm{D}}$ : Escoamento direto; Tempo ED: tempo de duração estimada do escoamento direto; $\mathrm{Q}_{\mathrm{pv}}$ : Vazão instantânea no pico de vazão.

\begin{tabular}{crrrrrrr}
\hline Data & $\begin{array}{c}\text { Precipitação } \\
\text { mm }\end{array}$ & $\begin{array}{c}\mathrm{E}_{\mathrm{T}} \\
\mathrm{mm}\end{array}$ & $\begin{array}{c}\mathrm{E}_{\mathrm{B}} \\
\mathrm{mm}\end{array}$ & $\begin{array}{c}\mathrm{E}_{\mathrm{D}} \\
\mathrm{mm}\end{array}$ & $\begin{array}{c}\text { Tempo ED } \\
\text { h: min }\end{array}$ & $\begin{array}{r}\text { Cota máxima } \\
\mathrm{cm}\end{array}$ & $\begin{array}{c}\mathrm{Q}_{\mathrm{pv}} \\
\text { s s}^{-1}\end{array}$ \\
\hline $29 / 08 / 01$ & 21,8 & 3,2 & 1,1 & 2,1 & $13: 14$ & 20,7 & 75,8 \\
$21 / 12 / 00$ & 24,8 & 3,8 & 1,8 & 2,0 & $14: 13$ & 19,7 & 67,0 \\
$20 / 03 / 01$ & 29,0 & 5,7 & 2,4 & 3,3 & $15: 08$ & 20,3 & 72,5 \\
$25 / 01 / 02$ & 30,5 & 9,6 & 4,5 & 5,1 & $13: 17$ & 26,7 & 138,6 \\
$02 / 10 / 01$ & 32,5 & 6,7 & 1,5 & 5,2 & $14: 32$ & 27,5 & 148,7 \\
$17 / 02 / 02$ & 33,0 & 8,5 & 2,8 & 5,7 & $23: 35$ & 22,3 & 138,6 \\
$13 / 05 / 01$ & 45,5 & 5,7 & 1,3 & 4,4 & $12: 30$ & 32,3 & 216,6 \\
$16 / 02 / 01$ & 52,0 & 14,1 & 3,2 & 10,9 & $18: 24$ & 54,1 & 741,0 \\
$02 / 02 / 02$ & 60,0 & 18,8 & 3,5 & 15,3 & $26: 30$ & 42,8 & 424,6 \\
$01 / 02 / 02$ & 61,0 & 16,3 & 3,1 & 13,2 & $25: 35$ & 53,8 & 732,8 \\
$10 / 01 / 01$ & 69,5 & 19,4 & 3,1 & 16,3 & $22: 06$ & 66,3 & 1204,0 \\
\hline
\end{tabular}

Foi feito a análise de regressão entre a precipitação total do evento com o escoamento total e o escoamento base. Ao analisar a relação entre a precipitação e o escoamento total, encontra-se que corresponderia a uma relação linear com um coeficiente de determinação $r^{2}$ de 0,85 , o que estaria indicando que $85 \%$ das variações no escoamento total estariam explicadas pelas variações da precipitação. Para o escoamento direto, essa relação, também linear, produziu $\stackrel{r}{2}^{2}$ igual a 0,91 , o que indicaria que $91 \%$ das variações no escoamento direto estariam explicadas pela variável precipitação.

Os tempos de duração do escoamento direto estão entre 12 a 15 horas, enquanto as precipitações não superarem os $30 \mathrm{~mm}$. Acima deste valor pareceria que se iniciam mudanças do comportamento hidrológico da microbacia, cnforme será discutido na análise da qualidade de água da microbacia.

Em termos de porcentagens, o escoamento total, escoamento direto e escoamento base representariam $23 \%, 16,4 \%$, e 6,6\%, respectivamente, da precipitação, em relação aos eventos analisados. Este fato estaria indicando que pelo menos $80 \%$ da água 
permanece na microbacia, infiltrando-se no solo, sendo liberada posteriormente, sob a forma de escoamento base. Este tipo de comportamento hidrológico, resultado da proteção hidrológica da cobertura florestal da área, bem como o comportamento da infiltração da água no solo, foram também observados em outros trabalhos desenvolvidos nas outras microbacias experimentais da área (Arcova,1996; Arcova e Cico, 1997; Cicco et al, 1989;Cicco e Fujieda, 1992; Fujieda et al., 1997).

\subsubsection{Precipitação oculta}

Foi feita uma análise dos dados coletados na estação meteorológica para tentar verificar a influência das neblinas e da alta umidade relativa na precipitação total da área, em termos de acréscimos à precipitação convencional, devido ao processo de captação física pelo dossel. Foram analisados os dados de 18 de abril de 2001 até 18 de abril de 2002 resumidos na Tabela 4.

Considerando o período seco do ano, abril a agosto, que se observa na coluna

1 da Tabela 4, da análise dos dados correspondentes a 52 eventos no período, obtém-se 2,0 $\mathrm{dm}^{3}$ de água recebidos no coletor de neblinas, sendo que a medida no pluviômetro foi de $1,2 \mathrm{dm}^{3}$. Esta diferença $\left(0,8 \mathrm{dm}^{3}\right)$ corresponderia a uma diferença percentual de $67 \%$ a mais de água coletada no coletor em relação ao pluviômetro, que equivaleria a 6,7 mm de chuva. Este valor, por uma vez, representaria $17,7 \%$ a mais de chuva nesses eventos. A precipitação medida no pluviógrafo da estação meteorológica nos mesmos dias atinge os 4,5 mm. Ao relacionar a precipitação no pluviógrafo da estação meteorológica com a quantidade adicional de chuva medida no coletor de neblinas, ou seja, a precipitação oculta, seriam obtidos incrementos percentuais de até $343 \%$ nos eventos do período seco. Esta diferença (entre as comparações com o pluviômetro e o pluviógrafo) poderia indicar que estaria existindo uma captura de neblinas também no pluviômetro (provavelmente produzida pela modificação do recipiente de recepção da água, já que este não permite perdas por evaporação). 
Tabela 4. Precipitação oculta capturada no coletor de neblinas. 1: eventos de neblinas no período seco abril a agosto de 2001; 2: eventos de neblinas entre abril de 2001 a abril 2002; 3: total capturado entre abril 2001 a abril 2002. p pluviômetro; pg: pluviógrafo; \% (v/v): Percentual do volume de água medido no coletor comparado ao volume medido no pluviômetro; \% $\left(\mathrm{P}_{\mathrm{m}}\right)$ : percentual da quantidade de chuva a mais medida no coletor em referência à medição do pluviômetro; \% $\left(\mathrm{p}_{\mathrm{g}}\right)$ : percentual da quantidade de chuva a mais medida no coletor em referencia à medição do pluviógrafo.

\begin{tabular}{lccc}
\hline & 1 & 2 & 3 \\
& Período seco & Só Neblinas & Total \\
\hline $\mathrm{N}^{\mathrm{o}}$ eventos & 52 & 87 & 343 \\
Coletor $\left(\mathrm{dm}^{3}\right)$ & 2,0 & 3,1 & 69 \\
Pluviômetro $\left(\mathrm{dm}^{3}\right)$ & 1,2 & 1,7 & 53 \\
Diferença $\mathrm{p}_{\mathrm{m}}\left(\mathrm{dm}^{3}\right)$ & 0,8 & 1,4 & 16 \\
$\%(\mathrm{v} / \mathrm{v})$ & 67 & 78 & 30 \\
Precipitação $\mathrm{p}_{\mathrm{m}}(\mathrm{mm})$ & 38 & 56 & 1695 \\
Diferença $\mathrm{p}_{\mathrm{m}}(\mathrm{mm})$ & 4,5 & 11,5 & 134 \\
$\%\left(\mathrm{p}_{\mathrm{m}}\right)$ & 18 & 21 & 8 \\
Precipitação $\mathrm{p}_{\mathrm{g}}(\mathrm{mm})$ & 4,5 & 16 & 1578 \\
Diferença $\mathrm{p}_{\mathrm{g}}(\mathrm{mm})$ & 15,4 & 22 & 566 \\
$\%\left(\mathrm{p}_{\mathrm{g}}\right)$ & 343 & 138 & 36 \\
\hline
\end{tabular}

Tendo em conta somente os eventos de neblinas e condensação de umidade (Tabela 4, coluna 2), no período total analisado foram identificados 87 eventos. O volume total coletado neles foi de $3,1 \mathrm{dm}^{3}$, enquanto que no pluviômetro foram coletados $1,7 \mathrm{dm}^{3}$, com uma diferença líquida de $1,4 \mathrm{dm}^{3}$ a mais no coletor de neblinas, correspondendo a $78 \%$ a mais em termos volumétricos do coletor em relação ao pluviômetro. Essa diferença, transformada em $\mathrm{mm}$ de precipitação, corresponderia a 11,5 mm, que comparados com a precipitação total determinada no pluviômetro (56 $\mathrm{mm}$ ), obtém-se um incremento de $21 \%$ na precipitação indicada no pluviômetro. Nos mesmos eventos, foram registrados $15 \mathrm{~mm}$ de precipitação no pluviógrafo da estação meteorológica, e relacionando estes com o ganho de água do coletor de neblinas obtémse neste último um ganho de $138 \%$ nos eventos. Novamente a diferença observada entre a captura de água no pluviômetro e no pluviógrafo reforçaria a hipótese de que existiria captura de neblinas no pluviômetro utilizado (Figura 15). 


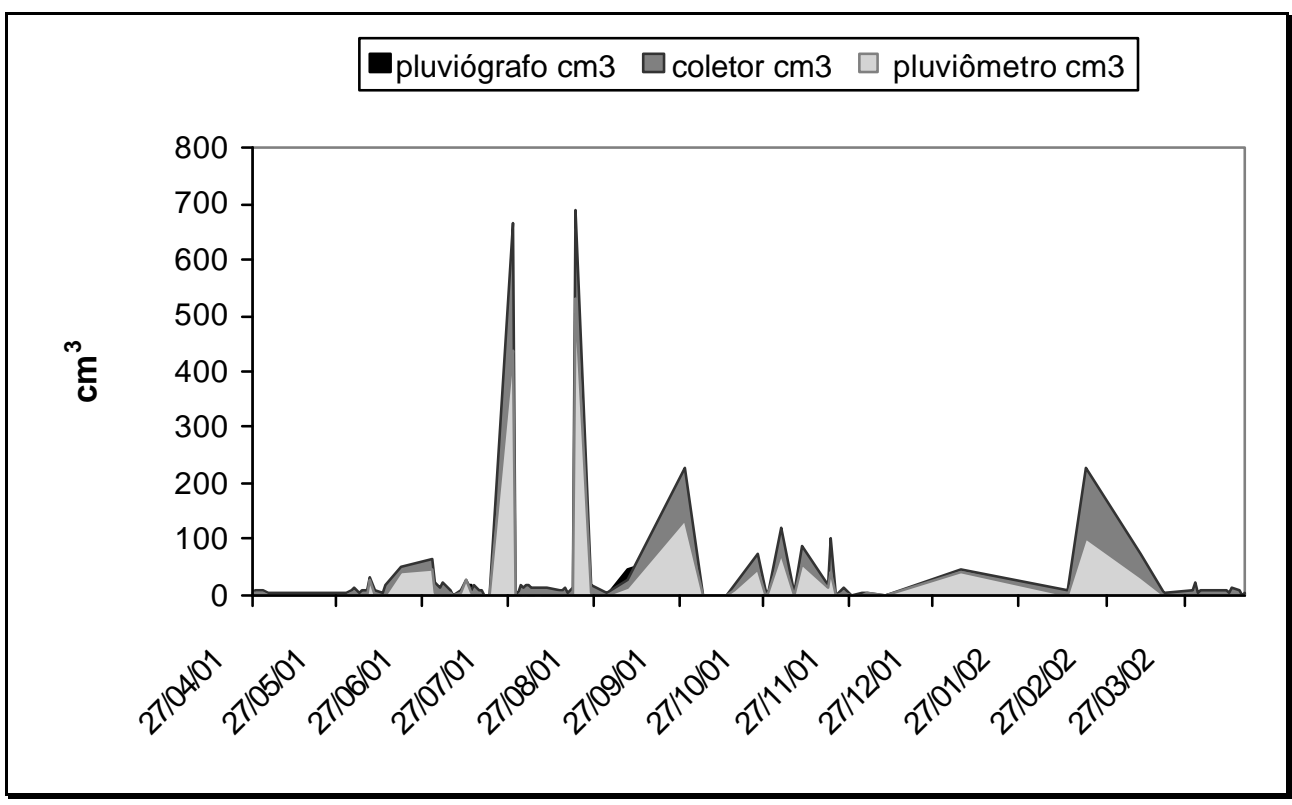

Figura 15 - Captação de neblinas pelo dossel florestal expresso como volume $\left(\mathrm{cm}^{3}\right)$ de água coletada pelo coletor de neblinas, pelo pluviômetro e pelo pluviógrafo colocados na Estação Meteorológica do Núcleo Cunha - Indaia, Parque Estadual da Serra do Mar - SP.

O volume total tanto de precipitação convencional quanto de neblinas no período total (abril de 2001 a abril de 2002) foi de $69 \mathrm{dm}^{3}$, enquanto que no pluviômetro foram coletados $53 \mathrm{dm}^{3}$, com uma diferença líquida de $16 \mathrm{dm}^{3}$ a mais no coletor de neblinas, equivalentes a $136 \mathrm{~mm}$ de precipitação (30\% superior em termos volumétricos do coletor em relação ao pluviômetro). Relacionando os valores em milímetros de altura de água no coletor de neblinas com a precipitação total determinada no pluviômetro no período $(1578 \mathrm{~mm})$, o acréscimo correspondente na precipitação total foi de 7,9 \%. Comparando, por outro lado, com a precipitação registrada no pluviógrafo, o acréscimo foi de $36 \%$ (Tabela 4, coluna 3).

Em resumo, poderia concluir-se que o processo de captação de neblinas pelo dossel florestal na região estaria acrescentando à chuva medida por métodos convencionais entre $8 \%$ até perto de $36 \%$ no ano. As proporções aumentam muito quando se considera somente os eventos de neblinas, coletando entre 1,5 a 3,5 vezes a mais do que indicaria o pluviógrafo nesses eventos. Isto condiz com o mencionado por 
Bruinjnzeel \& Hamilton (2000) para outras regiões de florestas de neblinas em regiões tropicais que sugere de 15 a $20 \%$ de acréscimo nas precipitações ordinárias em regiões com precipitações entre 2000 a 3000 mm por ano, e até 60\% sob condições extremas.

\subsection{Qualidade da água}

\subsubsection{Caracterização da qualidade da água do deflúvio (Turbidez e Cor aparente)}

Da análise dos resultados de turbidez e cor aparente pode-se observar suas flutuações no período setembro de 2000 a abril de 2002. Os picos observados correspondem as cheias ocasionadas pelas precipitações geralmente concentradas no período estival (Figura 16).

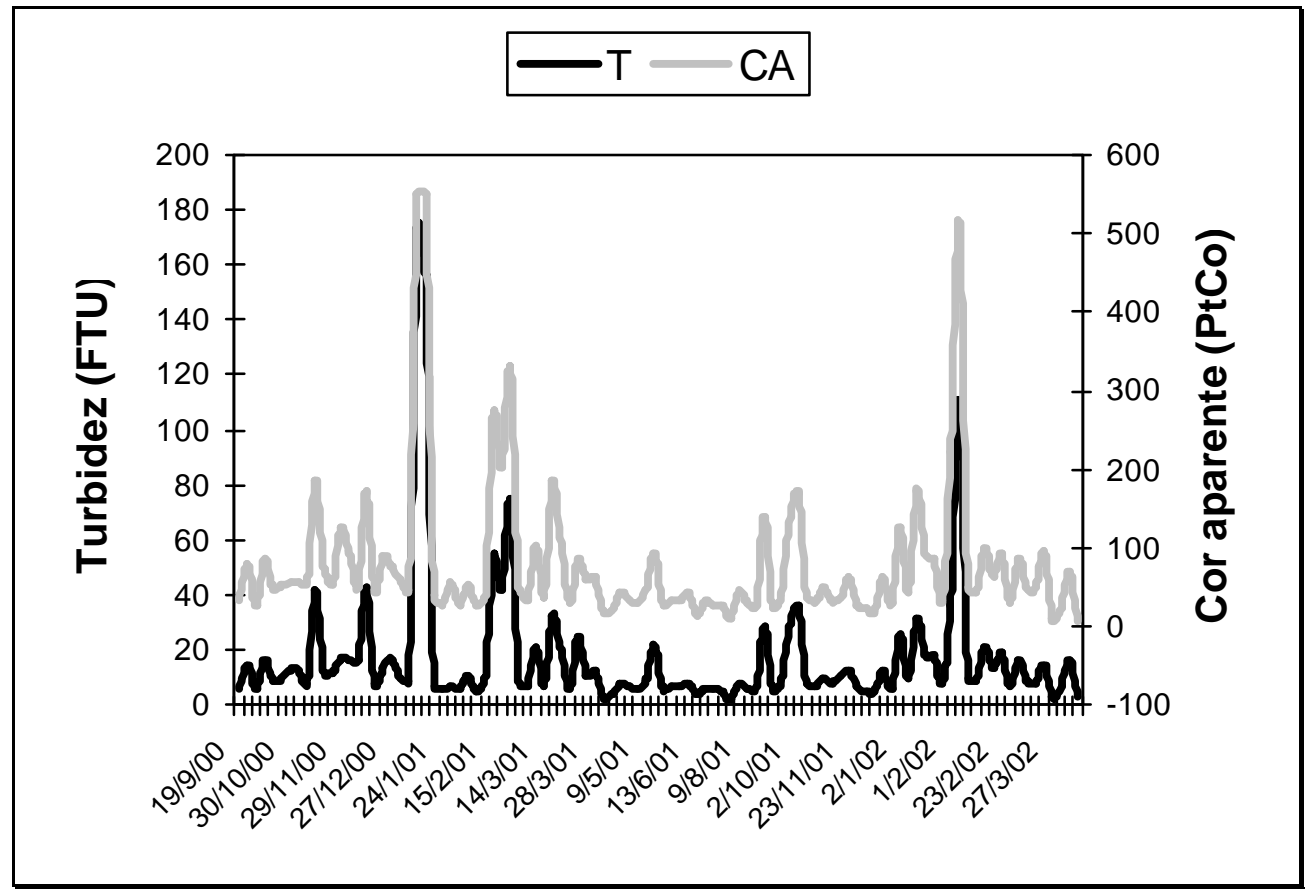

Figura 16 - Flutuações da turbidez (T), medida em unidades FTU, e da cor aparente (CA), medida em unidades de PtCo, da água do deflúvio da microbacia $\mathrm{A}$, no período Setembro de 2000 a abril de 2002. 
Correlacionando-se os valores de turbidez e cor aparente, obtém-se uma relação linear, com coeficiente de determinação $r^{2}$ de 0,964 que indicaria que as flutuações da cor aparente estariam explicadas na maioria dos casos pelas flutuações da turbidez. Esta relação não deve ser generalizada já que, nesta região, estaria influenciada pela alta proporção de sedimentos em suspensão voláteis (entre os quais a matéria orgânica teria uma participação muito alta) presente na água, que aumentam com as precipitações.

Analisando as respostas das variáveis turbidez e cor aparente em relação às precipitações pode-se observar que à medida que aumenta a intensidade das chuvas , ocorre um aumento das variáveis estudadas. Na Figura 17, observa-se que precipitações superiores a $30 \mathrm{~mm}$ são as responsáveis pelo aumento da turbidez, superando a turbidez média correspondente a 18 FTU. Eventos de chuvas que superarem $60 \mathrm{~mm}$ produziriam aumento na turbidez em até 9 vezes.

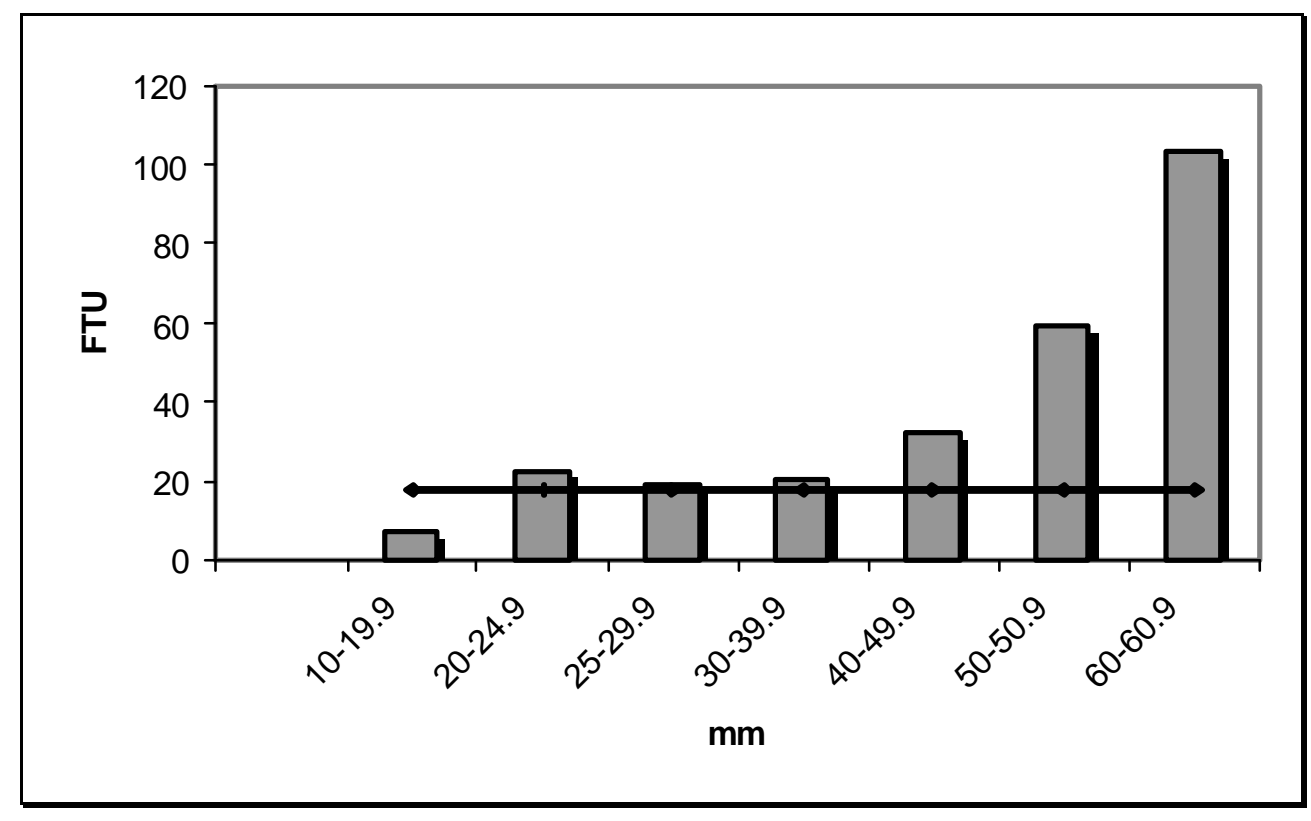

Figura 17 - Turbidez média da água do deflúvio segundo classe de precipitação. 


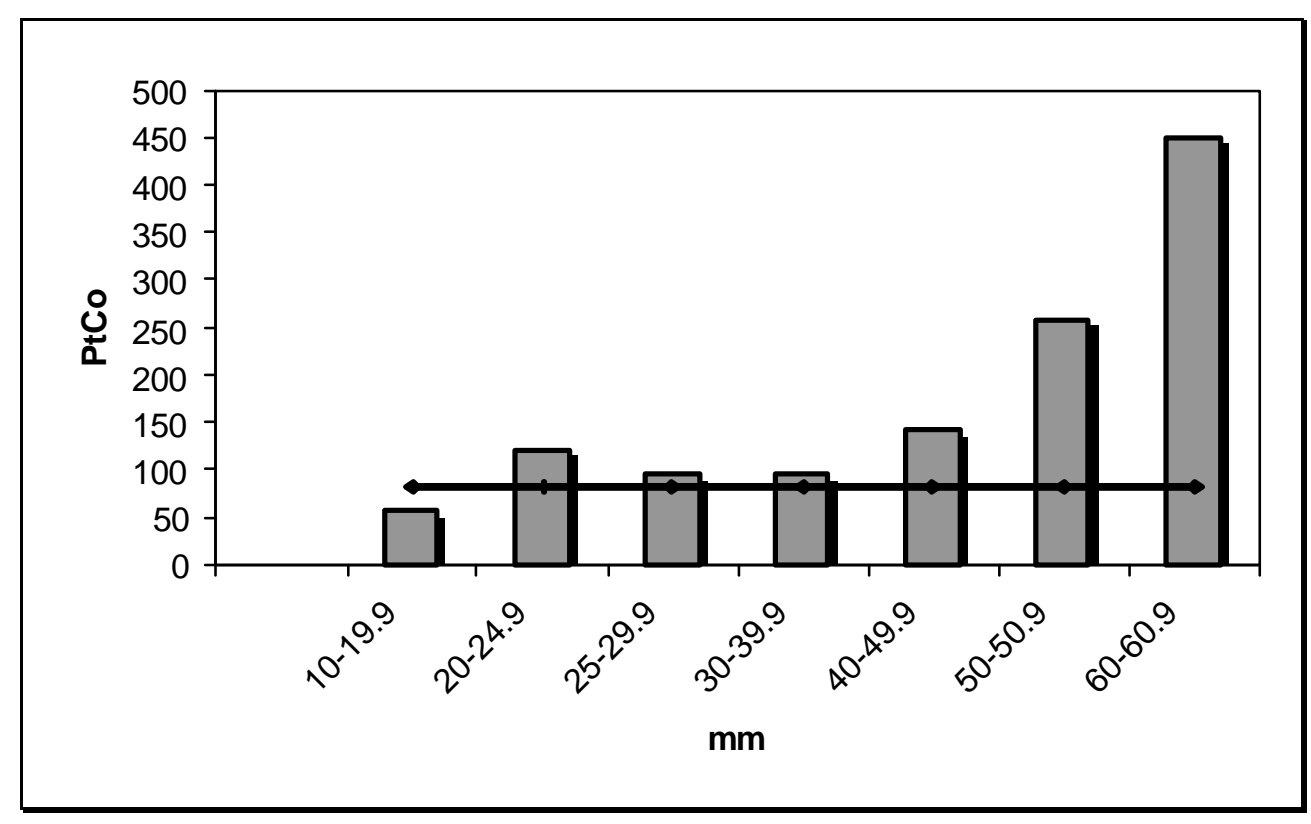

Figura 18 - Cor aparente média da água do deflúvio segundo classe de precipitação

As variações na cor aparente seguem também o mesmo comportamento que a turbidez. Quando a precipitação supera os $30 \mathrm{~mm}$, a cor aparente da água aumenta e as médias por classe superam a média geral de 81 PtCo (Figura 18). Assim, poderia inferirse que nas precipitações superiores a $30 \mathrm{~mm}$ tem-se o ponto de inflexão e acima deste valor começariam a ocorrer aumentos crescentes nos valores dos parâmetros estudados, em decorrência do aumento de material de arraste. Por esta razão, devem ser analisadas cuidadosamente as respostas ocasionadas por esses eventos.

Os valores da precipitação mensal e os valores mínimos, médios e máximos mensais de turbidez e cor aparente encontram-se na Tabela 5. Observa-se que os valores máximos de turbidez e cor aparente ocorreram nos meses de janeiro e fevereiro. Apesar de a precipitação total nestes meses ter sido inferior ao mês de dezembro e próximos aos de novembro e março, foi durante os meses de janeiro e fevereiro que ocorreram eventos de maior intensidade, produzindo valores extremos de turbidez e cor aparente. A precipitação média dos eventos analisados foi de $38 \mathrm{~mm}$. 
Tabela 5. Valores mínimos, médios e máximos da turbidez e da cor aparente da água do deflúvio do riacho da microbacia A. P: Precipitação média mensal expressada em mm, turbidez mínima, média e máxima mensal, expressada em unidades FTU, e cor aparente mínima, média e máxima, expressada em unidades de PtCo.

\begin{tabular}{|c|c|c|c|c|c|c|c|c|}
\hline \multirow{2}{*}{ Mes } & \multirow{2}{*}{$P m m$} & \multicolumn{4}{|c|}{ Turbidez (FTU) } & \multicolumn{3}{|c|}{ Cor aparente (PtCo) } \\
\hline & & mínima & & média & máxima & mínima & média & máxima \\
\hline Outubro. & 107 & & 6 & 15 & 36 & 26 & 70 & 171 \\
\hline Novembro & 211 & & 8 & 15 & 42 & 33 & 76 & 187 \\
\hline Dezembro & 253 & & 5 & 16 & 43 & 19 & 72 & 173 \\
\hline Janeiro & 196 & & 6 & 35 & 173 & 28 & 137 & 550 \\
\hline Fevereiro & 244 & & 5 & 27 & 111 & 27 & 130 & 516 \\
\hline Março & 216 & & 3 & 12 & 21 & 9 & 62 & 103 \\
\hline Abril & 26 & & 3 & 8 & 17 & 6 & 36 & 70 \\
\hline Maio & 94 & & 6 & 10 & 22 & 28 & 45 & 94 \\
\hline Junho & 2 & & 4 & 6 & 8 & 15 & 30 & 43 \\
\hline Julho & 69 & & 2 & 5 & 8 & 10 & 27 & 45 \\
\hline Agosto & 79 & & 6 & 18 & 29 & 31 & 86 & 141 \\
\hline Setembro & 140 & & 6 & 9 & 15 & 25 & 45 & 79 \\
\hline
\end{tabular}

O valor máximo de turbidez encontrado no período foi de 173 FTU, correspondente a um evento de $69,5 \mathrm{~mm}$ de precipitação e uma vazão máxima de 1204 $1 \mathrm{~s}^{-1}$, com um escoamento total de $19,4 \mathrm{~mm}$ (30\% da precipitação) e um escoamento direto de 16,3 mm (23\% da precipitação). As características do evento podem ser observadas na Figura 19. A máxima intensidade de chuva foi de $25 \mathrm{~mm} \mathrm{~h}^{-1}$. Neste mesmo evento foi registrado o máximo valor para a cor aparente obtendo-se valores ao redor de 550 PtCo.

Os valores mínimos encontrados corresponderam a uma turbidez de 2 FTU no mês de julho de 2001 e a cor aparente de 6 PtCo no mês de abril de 2002. Assim, podese inferir que a turbidez e a cor aparente não dependem somente das quantidades da chuva, mas com certeza deve haver outros fatores associados, principalmente em termos de condições antecedentes de umidade na microbacia, distribuição e intensidade das chuvas, etc. 


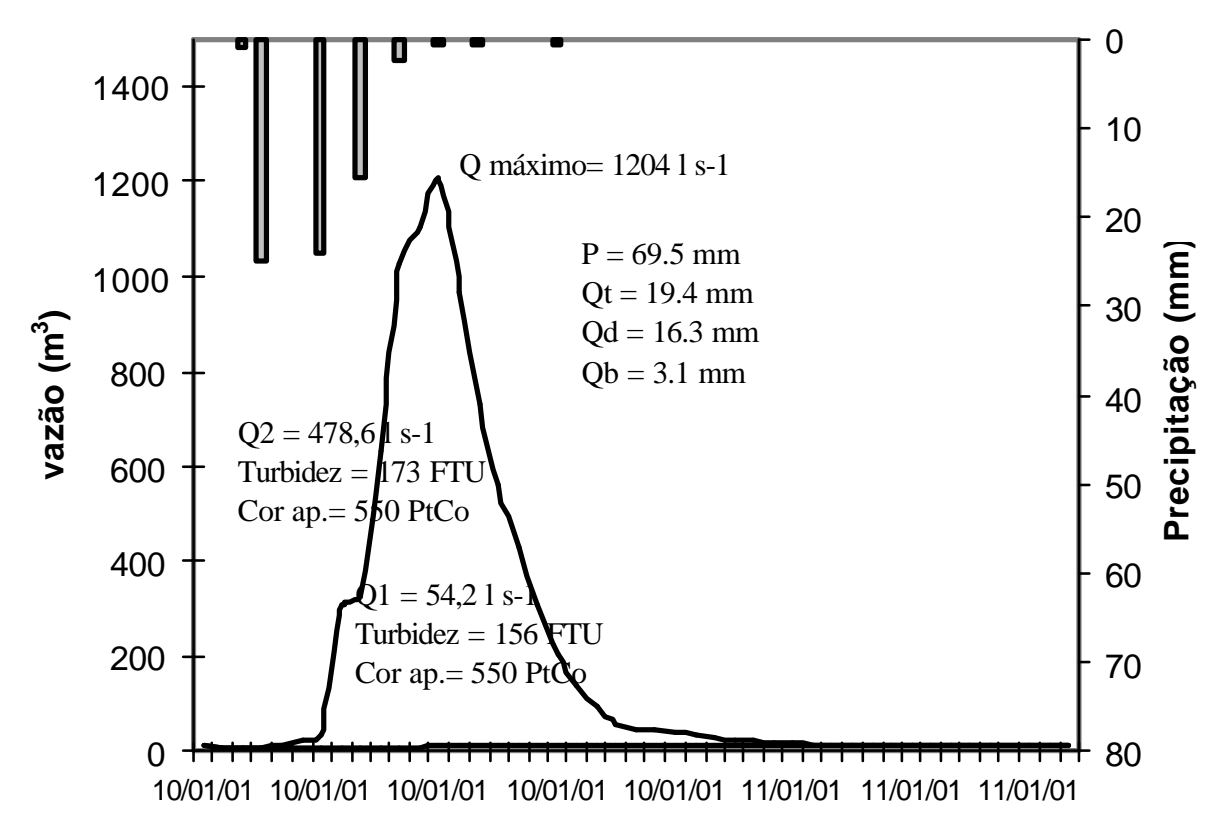

Figura 19 - Hidrograma correspondente ao evento ocorrido o dia 10/01/01. P: precipitação, Qt: escoamento total, Qd: escoamento direto, e Qb: escoamento base; em mm.

Considerando-se somente as coletas semanais de água, foram determinadas as médias mensais e os intervalos de confiança para o 95\% de probabilidade (Figura 20). A turbidez média mensal das coletas semanais varia entre 5 FTU no mês de julho até 13 FTU no mês de outubro. As maiores amplitudes dos intervalos de confiança ocorreram no mês de outubro. A turbidez média das coletas semanais (desprezando aquelas amostras correspondentes às enchentes) foi de 9 FTU, com um intervalo de confiança para 95\% de probabilidade entre 7,9 FTU e 10,1 FTU, e um desvio padrão de 4,9. Comparando-se os resultados com os mencionados por Arcova \& Cicco (1999), os valores estariam próximos aos obtidos na microbacia B, de 10,6 FTU, e superiores aos da microbacia D, de 5,1 FTU. Foram considerados também os eventos de chuvas que produziram enchentes que ultrapassaram $20 \mathrm{~cm}$ de altura da lâmina de água no vertedor. Determinaram-se assim, as médias mensais da totalidade dos dados e seus intervalos de confiança (Figura 21). 


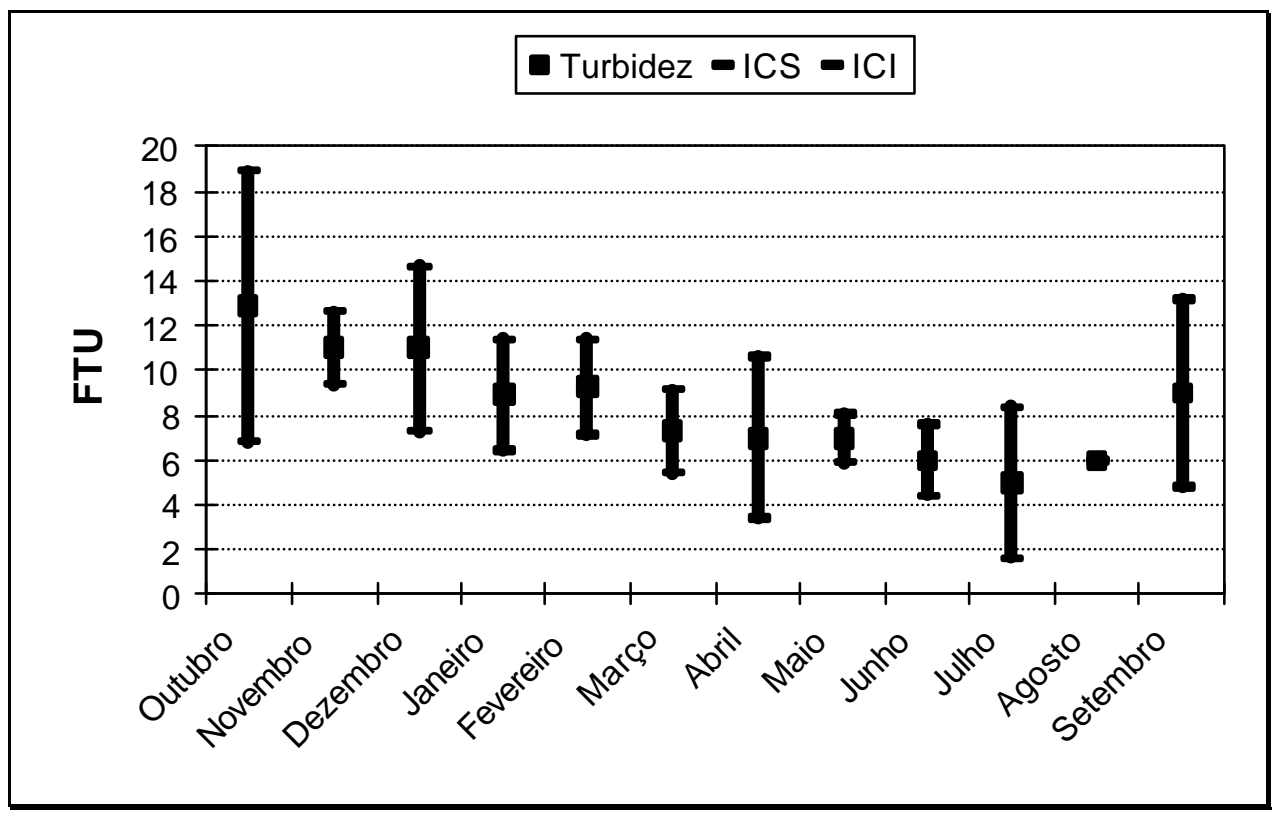

Figura 20 - Turbidez média mensal das coletas semanais da água do riacho da microbacia A. ICS: limite superior do intervalo de confiança, ICI: limite inferior do intervalo de confiança.

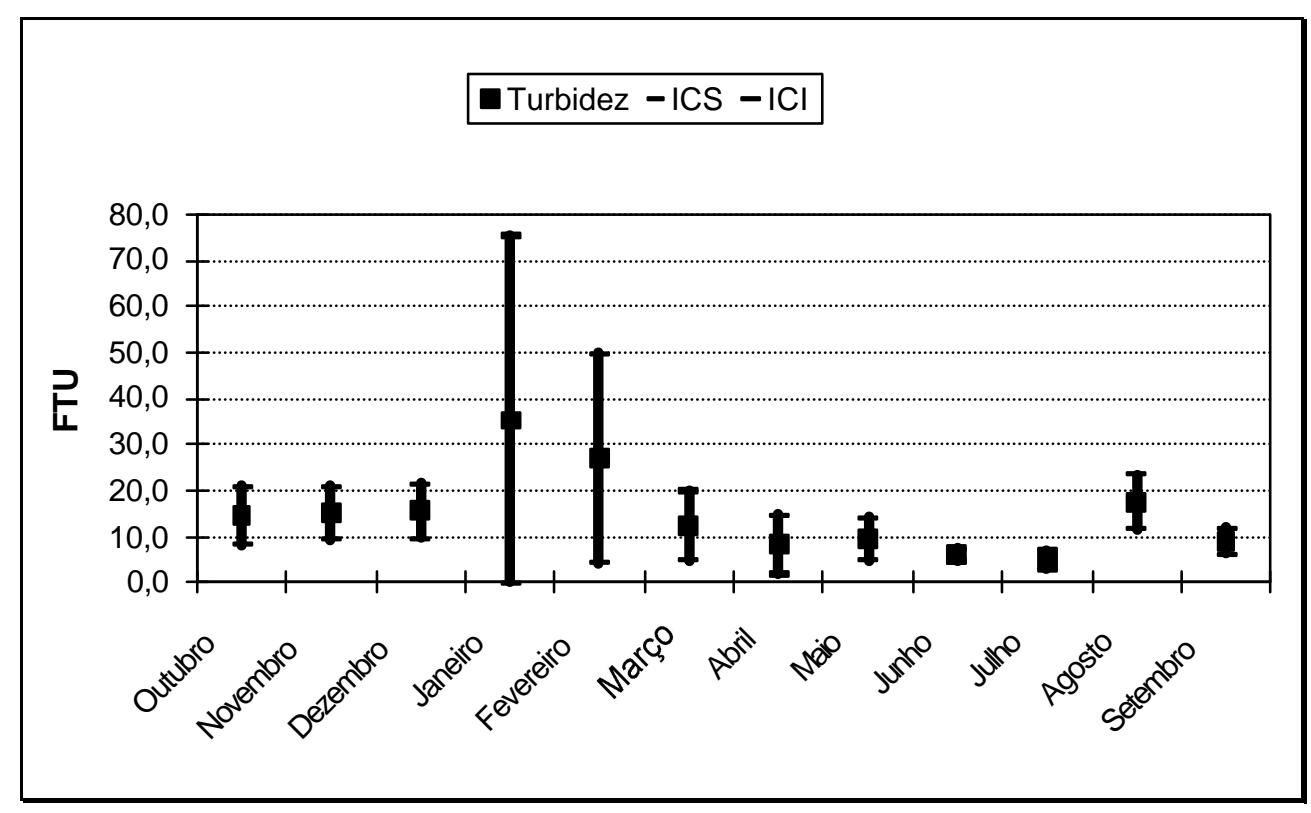

Figura 21 - Turbidez média mensal da água do riacho da microbacia A. ICS: limite superior do intervalo de confiança, ICI: limite inferior do intervalo de confiança. 
Da comparação das figuras anteriores (Figuras 20 e 21), ao incorporar as amostras correspondentes às enchentes, observaram-se mudanças produzidas na escala dos gráficos. Os valores mínimos de turbidez permanecem constantes e iguais a 5 FTU, mas os máximos variaram alcançando médias de 35,3 FTU no mês de janeiro. Houve uma amplitude maior nos intervalos de confiança nos messes de janeiro e fevereiro, onde a distribuição da precipitação foi mais uniforme e ocorreram chuvas de maior intensidade.

Da mesma forma que para turbidez, foram analisados os dados de cor aparente da água obtendo-se as médias e intervalos de confiança para as coletas semanais (Figura 22) e de todos os dados (Figura 23).

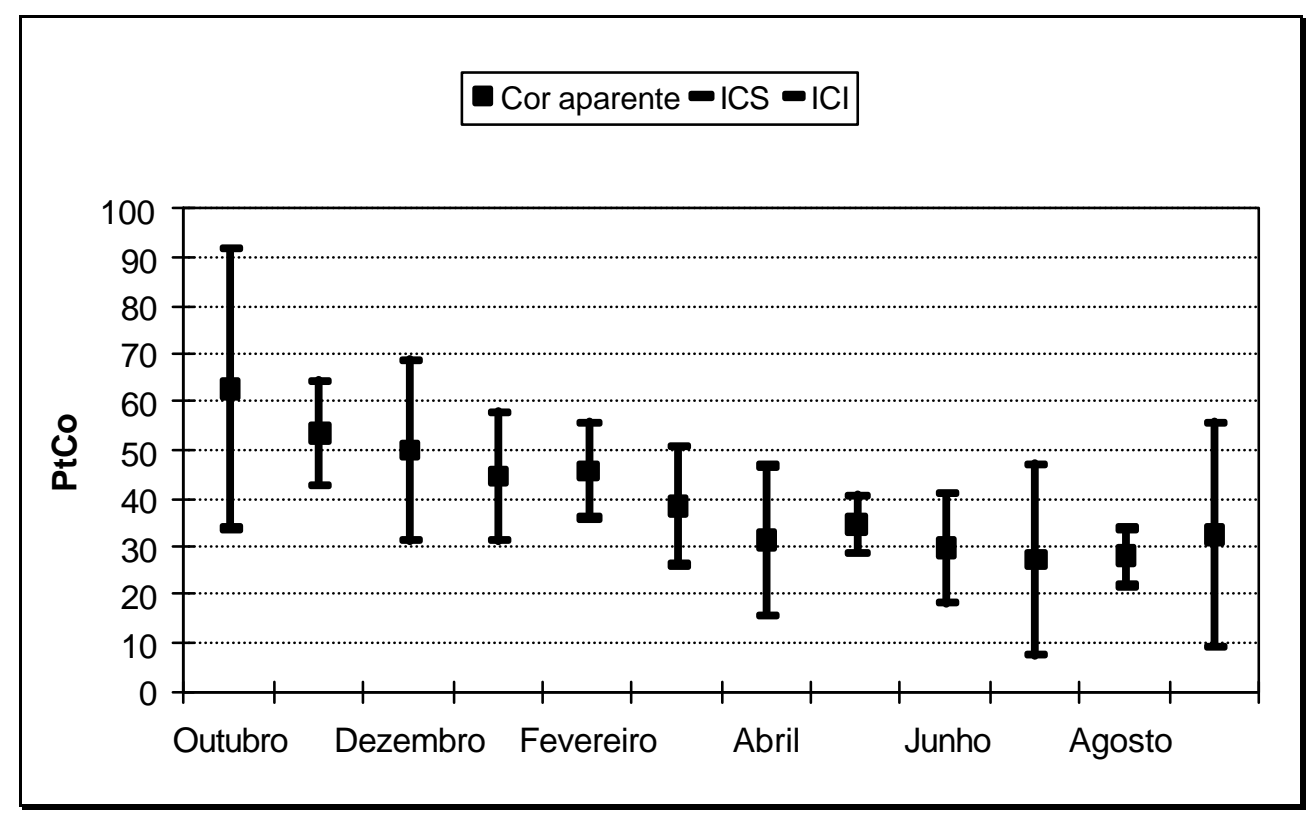

Figura 22 - Cor aparente média mensal das coletas semanais da água do riacho da microbacia A. ICS: limite superior do intervalo de confiança, ICI: limite inferior do intervalo de confiança.

A cor aparente média mensal das coletas semanais varia entre 27 PtCo no mês de julho até 63 PtCo no mês de outubro, correspondendo-se com as mínimas e máximas de turbidez. As maiores amplitudes dos intervalos de confiança apresentaram-se no mês de 
outubro. A cor aparente média das coletas semanais foi de $44 \mathrm{PtCo}$, com um intervalo de confiança para 95\% de probabilidade entre 36,7 e 51,1 PtCo, com um desvio padrão de 24,2. Lennox et al. (1997) afirmam que as coletas semanais ou quinzenais em rios de pequeno porte representam, em $80 \%$ das vezes, as características de qualidade de água do escoamento base, correspondendo-se isto com os resultados obtidos das coletas semanais.

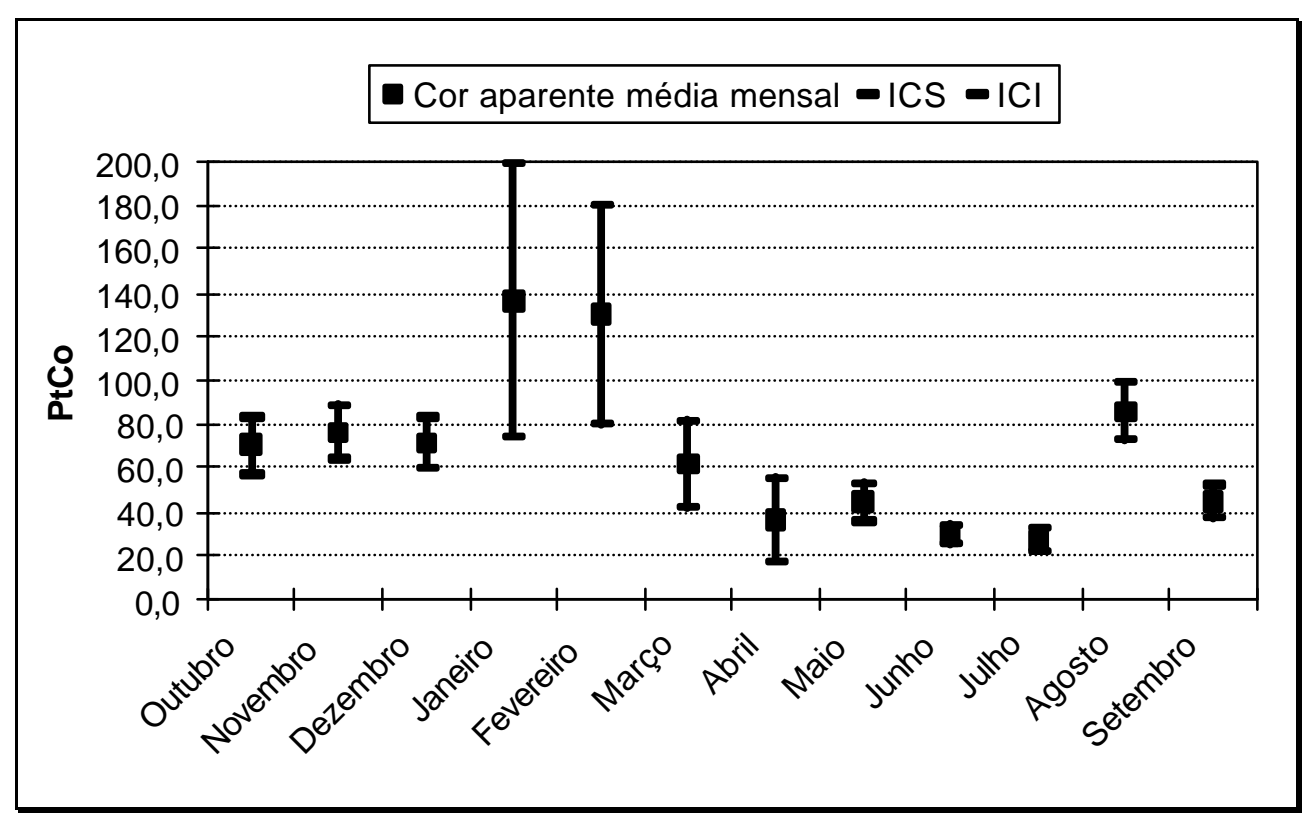

Figura 23 - Cor aparente média mensal da água do riacho da microbacia A. ICS: limite superior do intervalo de confiança, ICI: limite inferior do intervalo de confiança.

O comportamento da cor aparente da água do deflúvio, ao incorporar todas as amostras, é modificado (Figura 23). Assim, observa-se que as médias e os intervalos de confiança mudam de escala, conservando-se os valores mínimos de 27,3 Pt Co para o mês de julho, mas aumentando os máximos a 137 PtCo no mês de janeiro. As maiores amplitudes dos intervalos de confiança registraram-se nos meses de janeiro e fevereiro. Estes resultados correspondem-se com aqueles observados na turbidez da água.

Segundo Toledo \& Nicolella (2002), em trabalhos desenvolvidos em Guaíra SP, a nfluência da precipitação na qualidade da água não é significativa, (fato este que 
poderia estar associado ao tamanho da bacia, e ao fato de ser considerada a precipitação total mensal), apesar de observar-se uma deterioração na qualidade da água nos meses da estação chuvosa. Isto apoiaria o que aconteceu com as variáveis analisadas no presente estudo. Também citam que as variáveis mais relacionadas ao escoamento superficial seriam a turbidez e os sólidos totais em suspensão.

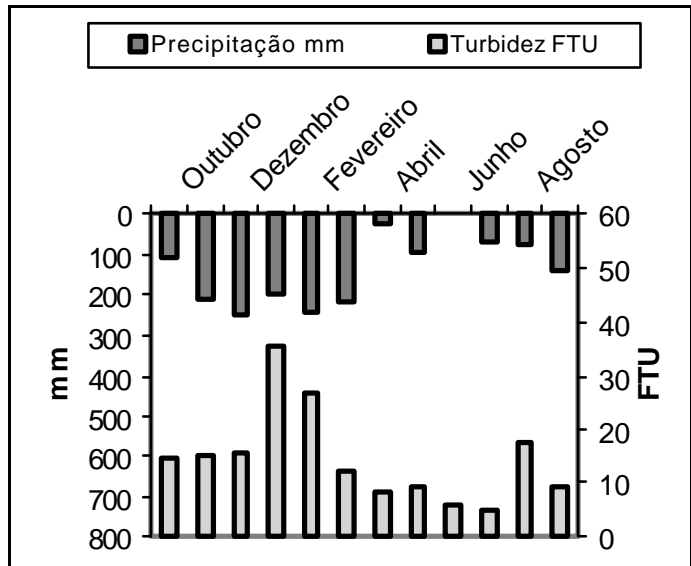

A

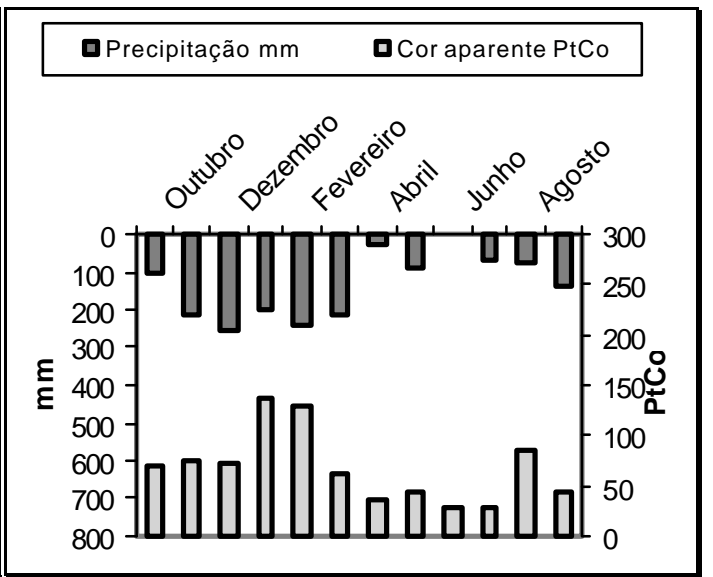

B

Figura 24 - A: Turbidez média mensal em unidades FTU e precipitação média mensal da água do riacho da microbacia A. B: Cor aparente média mensal em unidades PtCo e precipitação média mensal da água do riacho da microbacia $\mathrm{A}$.

Na Figura 24 pode-se observar que os maiores valores da turbidez e cor aparente estariam relacionados com os períodos de maior precipitação, mas não de forma linear. Este comportamento daria lugar a uma ampliação das causas das variações destes parâmetros, que não estaria ao alcance desta dissertação e daria lugar a trabalhos de pesquisa posteriores.

\subsubsection{Quantificação das perdas médias de sedimentos em suspensão na água do deflúvio}

Analisando a distribuição das concentrações de sedimentos em suspensão no período estudado, observa-se que os valores máximos correspondem às cheias 
ocasionadas pelas chuvas estivais, conforme é mostrado na Figura 25. O valor máximo de sedimentos em suspensão carregados pelas águas ocorreu em um evento de chuva de 69,5 mm, com uma vazão máxima de $1204 \mathrm{l} \mathrm{s}^{-1}$ que ocasionou uma concentração máxima de sedimentos em suspensão de 465,2 $\mathrm{mg} \mathrm{l}^{-1}$. Do total de sedimentos em suspensão transportados, $190 \mathrm{mg} \mathrm{l}^{-1}$ corresponderam a sedimentos fixos e $275 \mathrm{mg} 1^{1}$ foram sedimentos voláteis. A concentração média de sedimentos totais em suspensão no período foi de $22,5 \mathrm{mg} \mathrm{I}^{1}$, dos quais $7,4 \mathrm{mg} \mathrm{I}^{1}$ (33\%) corresponderiam a sedimentos em suspensão fixos (porção inorgânica) e $15 \mathrm{mg} \mathrm{l}^{-1}$ (67\%) a sedimentos em suspensão voláteis (porção orgânica, já que apesar da possível volatilização de alguns sais minerais (APHA, 1995), a matéria orgânica desaparece no processo de calcinação).

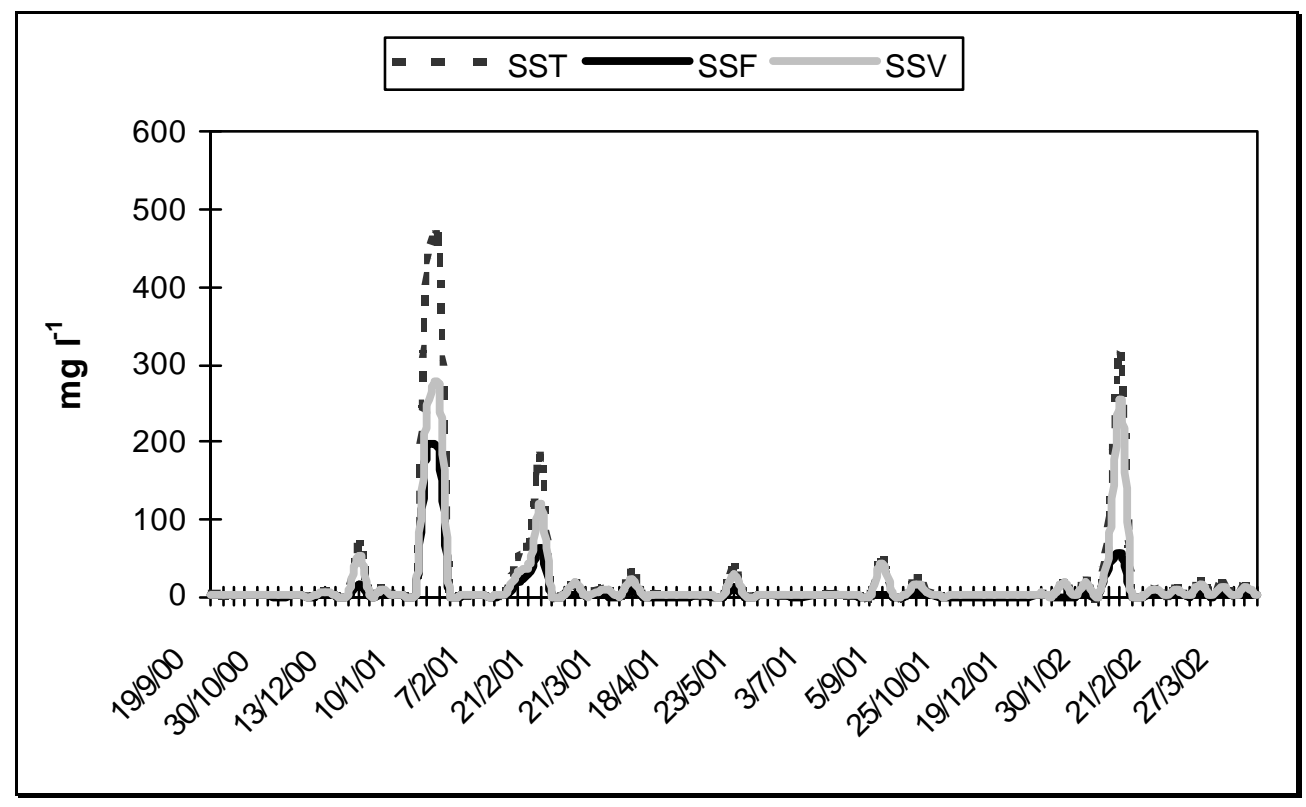

Figura 25 - Concentração em mg $I^{1}$ dos sedimentos em suspensão totais (SST), sedimentos em suspensão fixos (SSF) e sedimentos em suspensão voláteis (SSV), da água do riacho da microbacia $\mathrm{A}$.

Ao correlacionar os sedimentos em suspensão das amostras e as precipitações diárias, os incrementos nos sedimentos em suspensão seguem uma relação linear do tipo exponencial com as precipitações, com um coeficiente de determinação $\mathrm{r}^{2}$ de 0,82 . Isto indicaria que, na maioria dos casos, este incremento estaria relacionado com a 
magnitude das precipitações. $\mathrm{O}$ aumento das precipitações resulta num aumento das concentrações de sedimentos em suspensão. Deve ser considerado todavia que a concentração de sedimentos varia também com a vazão, e esta, por sua vez, depende das condições de umidade antecedente da microbacia.

Considerando somente as coletas semanais de água foram determinadas as médias mensais e os intervalos de confiança para $95 \%$ de probabilidade dos sedimentos em suspensão da água (Figura 26).

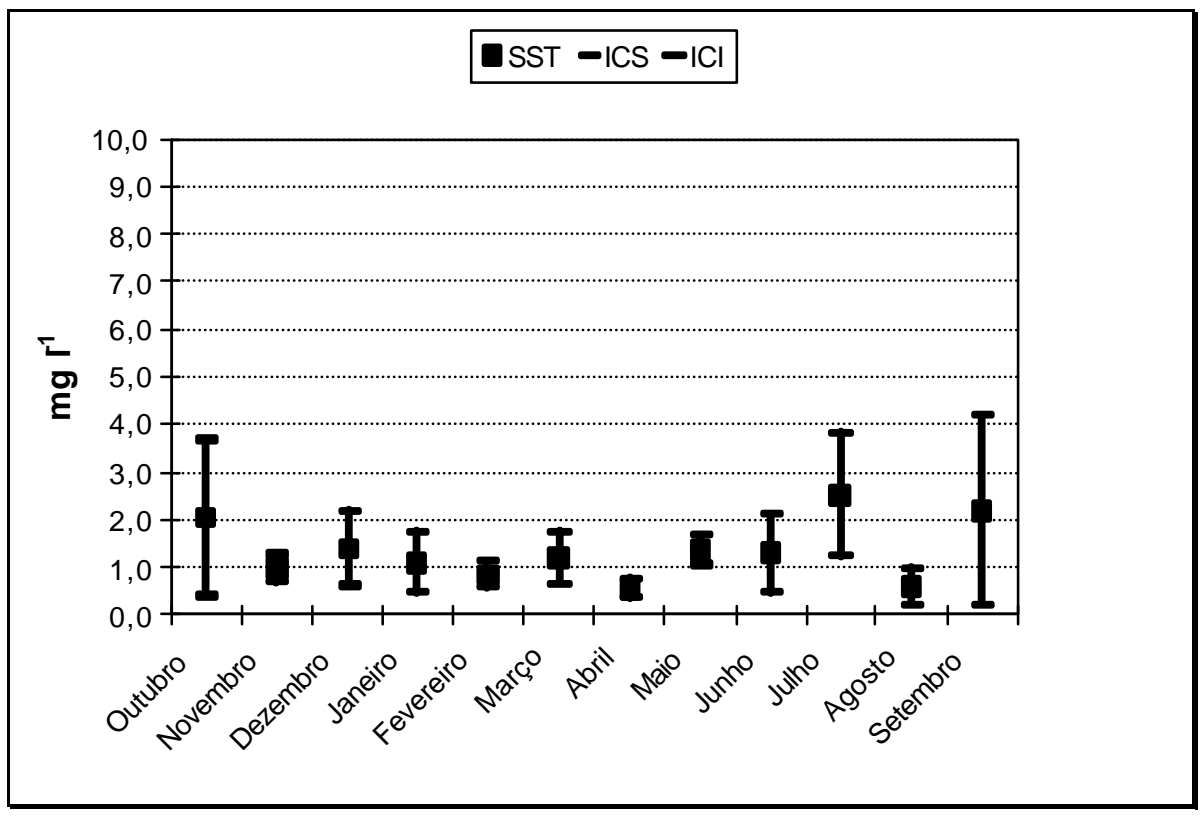

Figura 26 - Sedimentos em suspensão médios mensais (SST) em $\mathrm{mg}^{-1}$ das coletas semanais da água do riacho da microbacia A. ICS: limite superior do intervalo de confiança, ICI: limite inferior do intervalo de confiança.

Os sedimentos em suspensão totais das coletas semanais variam entre $0 \mathrm{mg} \mathrm{I}^{1}$ e 3,2 mg $1^{1}$, com uma média de $1,3 \mathrm{mg} \mathrm{l}^{-1}$, quase que desprezível se comparar, por exemplo, com trabalhos desenvolvidos em áreas com reflorestamento de Eucalyptus onde se tem concentrações médias mensais mínimas de 7,5 $\mathrm{mg} \mathrm{l}^{-1}$, e máximas de $48,8 \mathrm{mg} 1^{1}$ no primeiro ano após o corte raso (Vital et al., 1999). As maiores amplitudes nos intervalos de confiança ocorreram nos meses de setembro e outubro. Dos resultados 
de todas as amostras (semanais do vertedor mais as das garrafas de espera), foram determinadas assim, as médias mensais totais e seus intervalos de confiança (Figura 27).

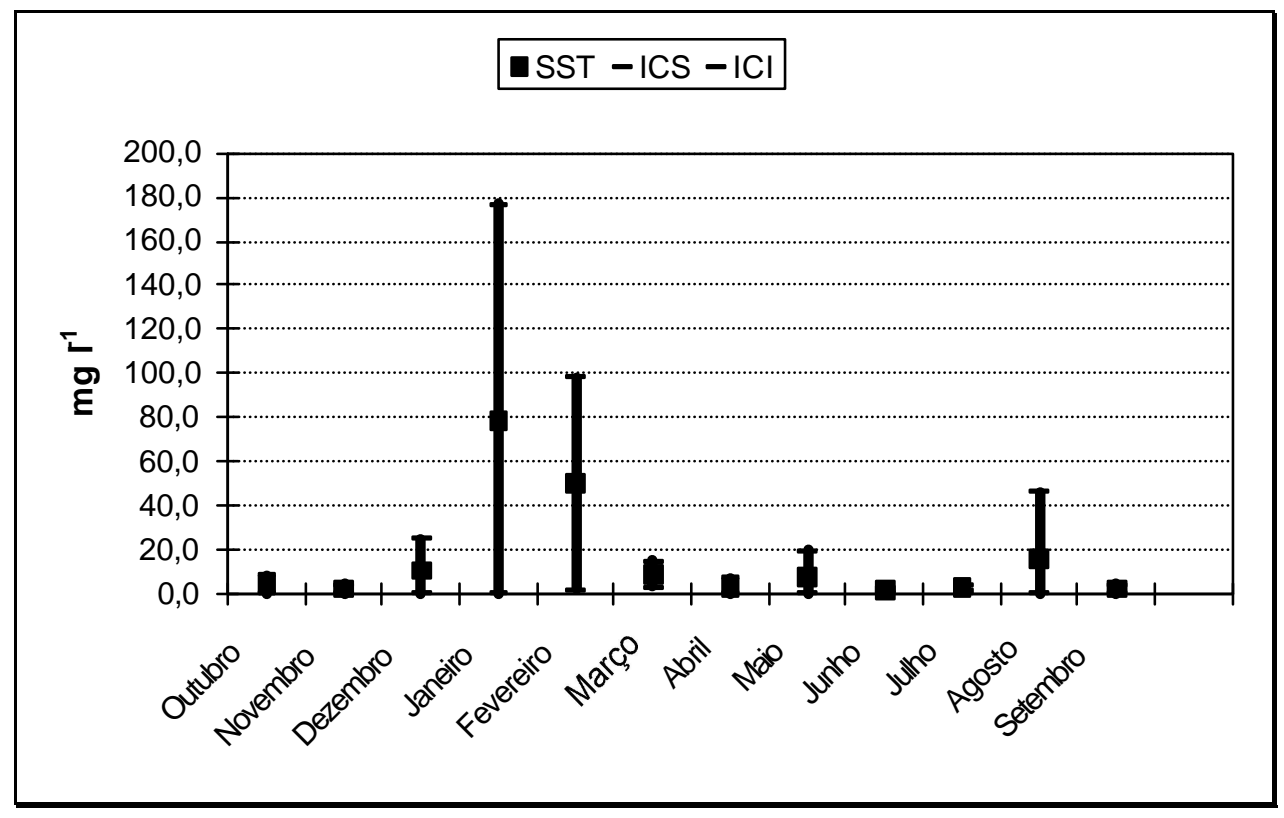

Figura 27 - Sedimentos em suspensão médios mensais em $\mathrm{mg} \mathrm{l}^{-1}$ da água do riacho da microbacia A. ICS: limite superior do intervalo de confiança, ICI: limite inferior do intervalo de confiança.

Observa-se, na Figura 27, como mudam as concentrações médias dos sedimentos em suspensão totais ao incorporar as amostras correspondentes às cheias, com médias mensais máximas de $79 \mathrm{mg}^{1}$ no mês de janeiro, para uma vazão média de $49.500 \mathrm{~m}^{3}$. Houve uma maior amplitude dos intervalos de confiança nos meses de janeiro e fevereiro, onde ocorreram as chuvas de maior quantidade e intensidade.

Como se pode observar na Figura 28, as frações de sedimentos em suspensão fixos (de caráter inorgânico) são praticamente desprezíveis (menor a 2,2 $\mathrm{mg} \mathrm{l}^{-1}$ ), ao longo de quase o ano todo, somente nos meses de janeiro e fevereiro aumentam consideravelmente, chegando a $32 \mathrm{mg} \mathrm{l}^{-1}$ no mês de fevereiro, fato este que resulta da proteção oferecida pela cobertura florestal na microbacia. As amplitudes dos intervalos 
de confiança também são maiores nestes meses, devido às diferenças no transporte de sedimentos quando se produzem as chuvas intensas características desta época.

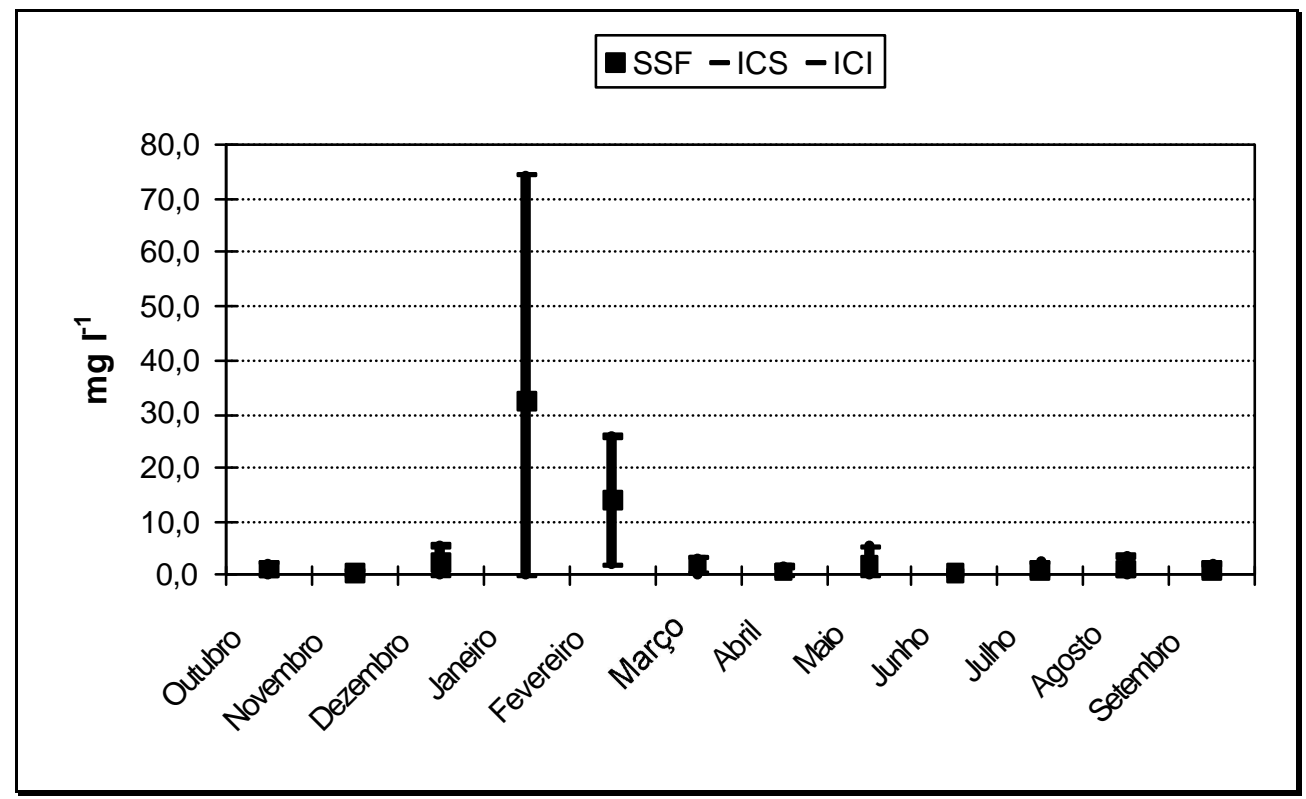

Figura 28 - Sedimentos em suspensão fixos médios mensais (SSF) em $\mathrm{mg} \mathrm{I}^{1}$ da água do riacho da microbacia A. ICS: limite superior do intervalo de confiança, ICI: limite inferior do intervalo de confiança.

Em trabalhos desenvolvidos em Quebec, Canadá, por Plamondon et al. (1982) em microbacias com floresta natural, em $90 \%$ do tempo os sedimentos em suspensão inorgânicos (fixos) se encontram abaixo de $5 \mathrm{mg} \mathrm{l}^{-1}$, com picos de $104 \mathrm{mg} \mathrm{l}^{-1}$ em microbacias submetidas a corte. Outros trabalhos mostram que a quantidade de sedimentos em suspensão inorgânicos chegariam a $1400 \mathrm{mg} \mathrm{l}^{-1}$ em microbacias com corte raso sem proteção da mata ciliar. Em local com movimentação de veículos produziu-se um pico de $25.000 \mathrm{mg}^{-1}$ depois de uma chuva de $30 \mathrm{~mm}$ (Plamondon, 1982). Ao comparar com os resultados deste estudo, estes resultados reforçam a hipóteses da existência de boas condições de conservação da área em estudo, e as condições dos parâmetros estudados de servir como indicadores para o monitoramento ambiental. 


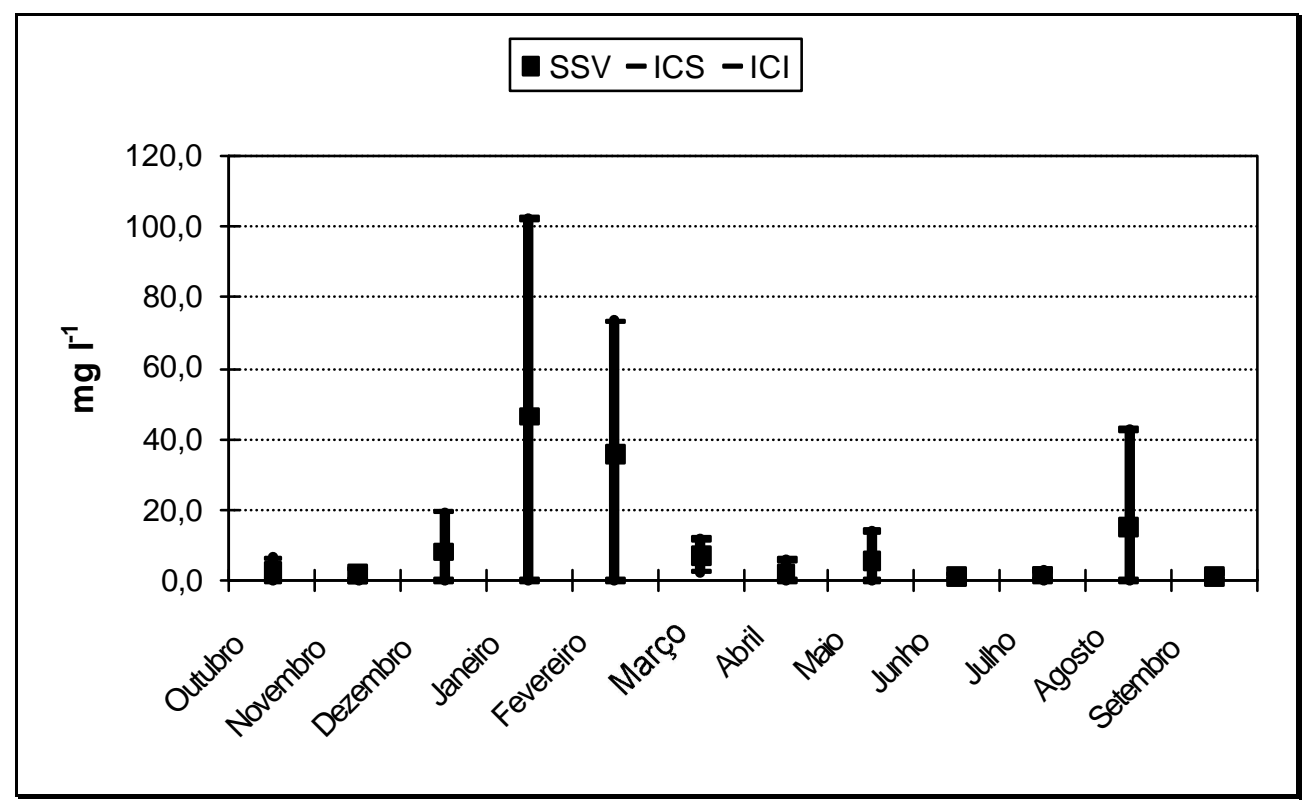

Figura 29 - Sedimentos em suspensão voláteis (SSV) médios mensais da água do riacho da microbacia A. ICS: limite superior do intervalo de confiança, ICI: limite inferior do intervalo de confiança.

Da mesma forma que para os sedimentos em suspensão fixos, os sedimentos em suspensão voláteis são mínimos e inferiores a $15 \mathrm{mg} \mathrm{I}^{1}$ durante quase o ano todo (Figura 29). Nos meses de janeiro e fevereiro se produzem os maiores valores com um valor médio máximo de $46,3 \mathrm{mg} \mathrm{l}^{-1}$.Poderia inferir-se que este fato segue as mesmas razões expostas anteriormente, e que é a boa cobertura florestal a responsável pelo baixo transporte de sedimentos em suspensão.

No trabalho desenvolvido por Plamondon (1982) citado anteriormente, as concentrações de partículas em suspensão orgânicas (voláteis) têm máximas de 120 $\mathrm{mg}^{-1}$ em áreas naturais, de $180 \mathrm{mg}^{1}$ em áreas submetidas a corte com mata ciliar não perturbada e de $2030 \mathrm{mg} \mathrm{l}^{-1} \mathrm{em}$ microbacias submetidas a corte, com mata ciliar perturbada pela movimentação de veículos.

Comparando-se as frações fixas e voláteis observa-se que em média, os sedimentos em suspensão da água seriam compostos de $33 \%$ de sedimentos em suspensão fixos (inorgânicos) e $67 \%$ de sedimentos em suspensão voláteis (orgânicos). 
Todavia as duas frações tendem a aumentar com as chuvas. Os primeiros aumentariam sua proporção com o aumento na quantidade e na intensidade da precipitação, até a porção fixa representar cerca de $40 \%$ dos sedimentos em suspensão totais em chuvas superiores a $60 \mathrm{~mm}$, cujas intensidades superaram $20 \mathrm{~mm} \mathrm{~h}^{-1}$ (Tabela 6).

Tabela 6. Concentrações de sedimentos em suspensão totais (SST), sedimentos em suspensão fixos (SSF) e sedimentos em suspensão voláteis (SSV) em mg $1^{1}$, das coletas nas garrafas de espera, segundo classe de precipitação $(\mathrm{P})$, para diferentes alturas da lâmina de água, e suas respectivas participações percentuais das frações fixas (\%SSF) e voláteis(\%SSV).

\begin{tabular}{|c|c|c|c|c|c|}
\hline $\begin{array}{c}\mathrm{P} \\
\mathrm{mm}\end{array}$ & $\begin{array}{c}\text { SST } \\
\mathrm{mg} \mathrm{I}^{1}\end{array}$ & $\begin{array}{c}\mathrm{SSF} \\
\mathrm{mg} \mathrm{I}^{1}\end{array}$ & $\begin{array}{l}\mathrm{SSV} \\
\mathrm{mg} \mathrm{I}^{-1}\end{array}$ & $\begin{array}{c}\% \\
\text { SSF }\end{array}$ & $\begin{array}{c}\% \\
\text { SSV }\end{array}$ \\
\hline $\mathrm{H}_{1}: 21 \mathrm{~cm}$ & & & & & \\
\hline $20-24,9$ & 22,5 & 2,2 & 20,2 & 10 & 90 \\
\hline $25-29,9$ & 9,4 & 1,7 & 7,8 & 18 & 83 \\
\hline $30-39,9$ & 17,0 & 3,7 & 13,3 & 22 & 78 \\
\hline $40-50$ & 38,0 & 10,8 & 27,2 & 28 & 72 \\
\hline $50-59,9$ & 69,6 & 22,6 & 47,0 & 32 & 68 \\
\hline $\begin{array}{l}60-69,9 \\
\mathrm{H}_{2}: 48 \mathrm{~cm}\end{array}$ & 282,6 & 114,4 & 168,2 & 40 & 60 \\
\hline $50-69,9$ & 308,1 & 104,0 & 204,1 & 34 & 66 \\
\hline Média eventos & 74,2 & 24,5 & 49,6 & 22 & 77 \\
\hline Média geral & 22,5 & 7,4 & 15,1 & 33 & 67 \\
\hline
\end{tabular}

A altura 1 (H1) corresponderia a vazões superiores a $78 \mathrm{l} \mathrm{s}^{-1}$, enquanto que a altura 2 (H2) corresponderia a vazões que superarem $480 \mathrm{l} \mathrm{s}^{-1}$. Da mesma forma que acontecera com os outros parâmetros estudados (turbidez e cor aparente), as precipitações que superarem a classe de $30 \mathrm{~mm}$ são as que produziram efeitos maiores no transporte de partículas em suspensão, superando a concentração média obtida de sedimentos totais de $22,5 \mathrm{mg} \mathrm{l}^{-1}$. 


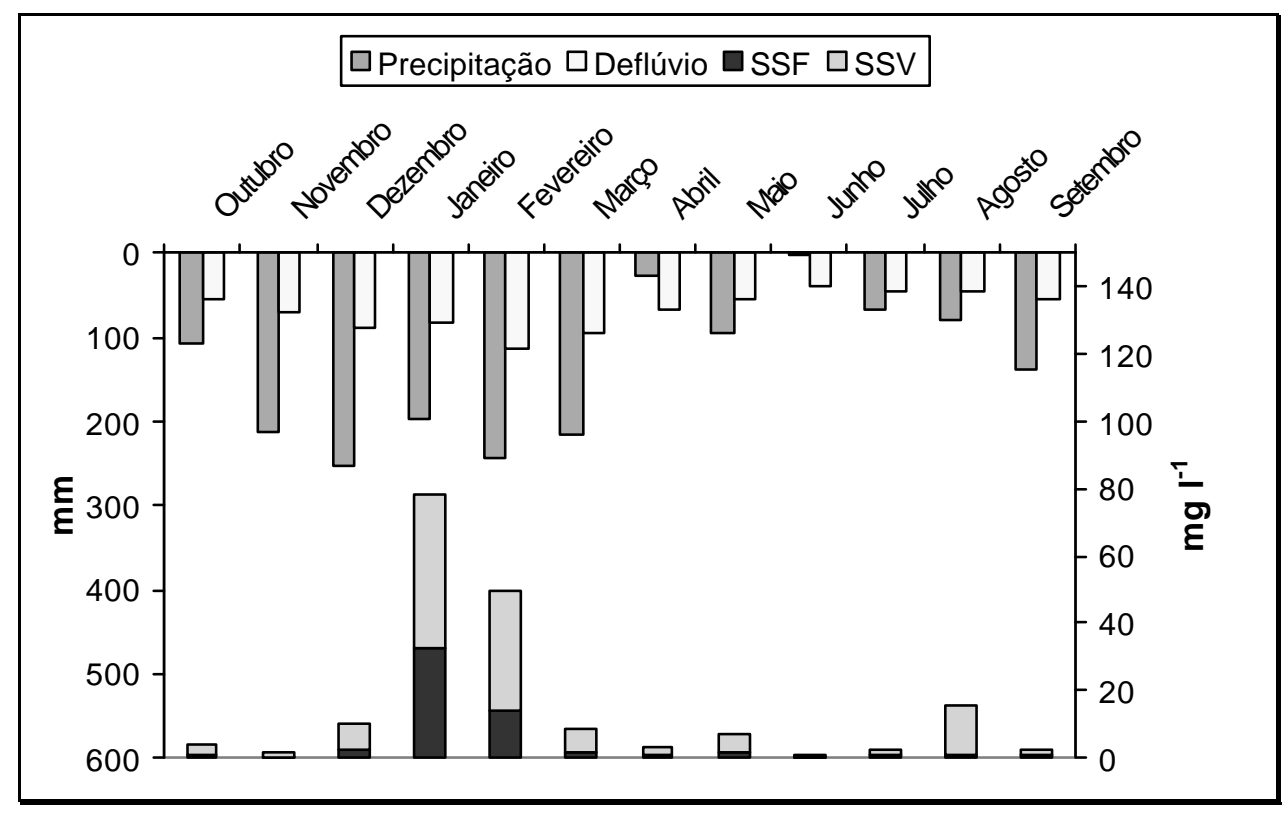

Figura 30 - Sedimentos em suspensão médias mensais de suas frações fixas (SSF) e voláteis (SSV), precipitação mensal média e deflúvio mensal médio.

Na Figura 30 observa-se que as proporções das frações voláteis seriam mais elevadas que aquelas fixas, e que, apesar de aumentar as concentrações de sedimentos nos períodos chuvosos, não teriam uma alta correlação com o total da precipitação ou do deflúvio mensal (Tabela 4). Plamondon (1982) afirma que, geralmente, em áreas de floresta natural a concentração de partículas orgânicas seriam mais altas que aquelas inorgânicas, já que o solo mineral não estaria exposto. Esta afirmação está em consonância com os resultados obtidos no presente estudo.

Foi feito o cálculo das perdas de solo de acordo com as concentrações e vazões médias mensais. Os resultados mostram que os meses com maiores perdas são novamente os meses de janeiro e fevereiro, com 77,5 e $45,7 \mathrm{~kg} \mathrm{ha}^{-1} \mathrm{mês}^{-1}$, respectivamente, mantendo-se na maioria do tempo restante abaixo de $5 \mathrm{~kg} \mathrm{ha}^{-1}$ mês ${ }^{-1}$, com mínimos de $0,5 \mathrm{~kg} \mathrm{ha}^{-1}$ mês $^{-1}$ no mês de junho. As perdas médias anuais seriam de $162 \mathrm{~kg} \mathrm{ha}^{-1} \mathrm{ano}^{-1}$. Estas perdas, se comparadas com trabalhos desenvolvidos no estado de Minas Gerais em rios de primeiro ordem (Santos, 1998), mostram ser insignificantes, mas tem a ver também com o tamanho da microbacia. No mesmo trabalho (Santos, 
1988), as perdas de sólidos totais transportados no rio foram de 1,6 ton $\mathrm{ha}^{-1} \mathrm{ano}^{-1}$, e também muito abaixo das estimativas para o estado de São Paulo que variam de 4,5 a 15 ton ha $^{-1}$ ano $^{-1}$ (Bertoni \& Lombardi Neto, 1990). Estes resultados reforçam a hipóteses da adequação deste parâmetro de servir como indicador para o monitoramento ambiental visando garantir a manutenção da saúde ambiental e a integridade da microbacia estudada.

Finalmente, ao se fazer uma matriz contemplando os coeficientes de determinação entre as diferentes variáveis estudadas, obtêm-se (Tabela 7):

Tabela 7. Matriz dos coeficientes de determinação das variáveis de quantidade e qualidade de água do riacho da microbacia $\mathrm{A}$.

\begin{tabular}{lrrrrrr}
\hline & Precipitação & Deflúvio & Turbidez & $\begin{array}{c}\text { Cor } \\
\text { aparente }\end{array}$ & $\begin{array}{c}\text { Perdas de } \\
\text { solo }\end{array}$ & SST \\
\hline Precipitação & 1 & 0,73 & 0,48 & 0,53 & 0,48 & 0,31 \\
Deflúvio & & 1 & 0,45 & 0,44 & 0,57 & 0,42 \\
Turbidez & & & 1 & 0,98 & 0,80 & 0,73 \\
Cor aparente & & & & 1 & 0,76 & 0,69 \\
Perdas de solo & & & & & & 0,96 \\
SST & & & & & & \\
\hline
\end{tabular}

As correlações entre os parâmetros de qualidade de água estudados indicariam uma alta relação entre eles, o que explicaria grande parte de suas variações $\left(\mathrm{r}^{2}\right.$ maior que 0,70, o que significa que as variações em qualquer uma delas explicaria mais de $70 \%$ das variações das outras duas). As correlações tanto com as precipitações quanto com os deflúvios mensais não foram boas, apesar de ser alta ao comparar com as precipitações diárias.

Como mencionado anteriormente, este comportamento deve ser entendido como um indicativo da necessidade de aprofundamento das causas das variações destes parâmetros, que não estaria ao alcance desta dissertação e daria lugar a trabalhos de pesquisa posteriores. 


\section{CONCLUSÕES}

A microbacia apresenta um balanço hídrico muito similar aos balanços hídricos medidos nas outras duas microbacias experimentais da área, que mostra uma evapotranspiração de $553 \mathrm{~mm}$ anuais. Isto estaria indicando a área como importante para

a produção de água, já que o consumo total da mesma é bastante baixo (32\% da precipitação convencional).

Dada a baixa evapotranspiração da região e os resultados da captura de neblinas obtidos, pode-se dizer que existiria um aumento na precipitação convencional de pelo menos $8 \%$, produzido pelo ingresso de água devido à precipitação oculta.

Os parâmetros de qualidade de água selecionados (turbidez, cor aparente e sedimentos em suspensão) poderiam servir como indicadores da qualidade da água de uma microbacia visando o monitoramento ambiental, considerando as flutuações obtidas no presente estudo como normais para uma área não perturbada e em boas condições de proteção florestal. O intervalo natural de variação obtido pode fornecer um referencial para o monitoramento ambiental.

Os valores destes indicadores flutuam com a intensidade das precipitações. Precipitações intensas e de curta duração seriam as responsáveis pelas maiores variações dos parâmetros escolhidos. Os valores destes aumentam com o aumento da magnitude e duração das precipitações, tendo que levar em conta as condições hídricas anteriores da microbacia, em termos de umidade antecedente. 
ANEXOS 
Anexo A

Precipitação mensal segundo anos hídricos

\begin{tabular}{lrrrrrrrr}
\hline & $\begin{array}{c}\mathbf{9 2 - 9 3} \\
\mathrm{mm}\end{array}$ & $\begin{array}{c}\mathbf{9 3 - 9 4} \\
\mathrm{mm}\end{array}$ & $\begin{array}{c}\mathbf{9 4 - 9 5} \\
\mathrm{mm}\end{array}$ & $\begin{array}{c}\mathbf{9 5 - 9 6} \\
\mathrm{mm}\end{array}$ & $\begin{array}{c}\mathbf{9 6 - 9 7} \\
\mathrm{mm}\end{array}$ & $\begin{array}{r}\mathbf{9 7 - 9 8} \\
\mathrm{mm}\end{array}$ & $\begin{array}{r}\mathbf{9 8 - 9 9} \\
\mathrm{mm}\end{array}$ & $\begin{array}{r}\mathbf{2 0 0 0 - 0 1} \\
\mathrm{mm}\end{array}$ \\
\hline Outubro & 118,0 & 165,5 & 181,1 & 343,8 & 149,3 & 153,5 & 287,8 & 105,0 \\
Novembro & 366,3 & 105,8 & 223,0 & 203,5 & 224,5 & 222,8 & 123,3 & 253,0 \\
Dezembro & 225,5 & 191,0 & 334,3 & 238,3 & 192,4 & 136,8 & 212,5 & 269,9 \\
Janeiro & 233,3 & 202,5 & 201,1 & 374,7 & 228,2 & 314,8 & 270,0 & 165,3 \\
Fevereiro & 271,5 & 207,3 & 342,3 & 520,7 & 50,4 & 285,0 & 337,1 & 187,3 \\
Março & 234,3 & 410,2 & 208,8 & 369,8 & 122,7 & 223,6 & 82,3 & 215,8 \\
Abril & 70,0 & 163,9 & 51,8 & 130,5 & 68,7 & 83,7 & 17,3 & 25,8 \\
Maio & 48,8 & 88,8 & 96,0 & 70,5 & 96,3 & 136,0 & 50,1 & 93,9 \\
Junho & 62,5 & 80,6 & 67,0 & 48,9 & 66,0 & 27,5 & 75,8 & 1,8 \\
Julho & 20,0 & 57,6 & 63,3 & 22,5 & 10,3 & 17,3 & 51,0 & 68,5 \\
Agosto & 7,0 & 16,4 & 40,1 & 36,8 & 62,1 & 35,0 & 33,8 & 79,0 \\
Setembro & 240,0 & 74,4 & 139,0 & 144,8 & 151,3 & 178,3 & 156,4 & 139,5 \\
Totais & $\mathbf{1 8 9 7 , 2}$ & $\mathbf{1 7 6 4 , 0}$ & $\mathbf{1 9 4 7 , 8}$ & $\mathbf{2 5 0 4 , 8}$ & $\mathbf{1 4 2 2 , 2}$ & $\mathbf{1 8 1 4 , 3}$ & $\mathbf{1 6 9 7 , 4}$ & $\mathbf{1 6 0 4 , 8}$ \\
\hline
\end{tabular}

Anexo B

Deflúvios mensais segundo anos hídricos

\begin{tabular}{|c|c|c|c|c|c|c|c|c|}
\hline & $\begin{array}{c}\mathbf{9 2 - 9 3} \\
\mathrm{mm}\end{array}$ & $\begin{array}{c}\text { 93-94 } \\
\mathrm{mm}\end{array}$ & $\begin{array}{c}\text { 94-95 } \\
\mathrm{mm}\end{array}$ & $\begin{array}{c}\text { 95-96 } \\
\mathrm{mm}\end{array}$ & $\begin{array}{c}\text { 96-97 } \\
\mathrm{mm}\end{array}$ & $\begin{array}{c}\mathbf{9 7 - 9 8} \\
\mathrm{mm}\end{array}$ & $\begin{array}{c}\text { 98-99 } \\
\mathrm{mm}\end{array}$ & $\begin{array}{c}\text { 2000-01 } \\
\mathrm{mm}\end{array}$ \\
\hline Outubro & 57,87 & 66,87 & 74,60 & 147,19 & 70,27 & 57,46 & 126,80 & $\overline{60,31}$ \\
\hline Novembro & 138,53 & 55,38 & 104,38 & 124,80 & 95,96 & 84,22 & 80,43 & 91,44 \\
\hline Dezembro & 140,50 & 74,64 & 161,19 & 129,04 & 90,99 & 68,43 & 94,92 & 111,79 \\
\hline Janeiro & 124,90 & 85,34 & 115,02 & 269,08 & 106,21 & 138,09 & 114,86 & 98,47 \\
\hline Fevereiro & 141,10 & 81,36 & 222,79 & 409,83 & 79,32 & 155,43 & 187,47 & 91,67 \\
\hline Marçc & 159,13 & 181,99 & 204,34 & 439,79 & 80,37 & 154,09 & 154,36 & 87,68 \\
\hline Abril & 130,87 & 180,93 & 132,94 & 274,14 & 54,84 & 104,32 & 124,03 & 55,20 \\
\hline Maio & 128,76 & 130,92 & 121,51 & 156,99 & 63,93 & 79,45 & 79,10 & 55,29 \\
\hline Junho & 106,77 & 101,17 & 75,12 & 112,71 & 57,68 & 51,78 & 69,73 & 38,30 \\
\hline Julho & 74,20 & 82,19 & 100,54 & 100,61 & 42,61 & 52,87 & 62,00 & 45,20 \\
\hline Agosto & 47,25 & 65,37 & 51,93 & 74,70 & 41,66 & 52,47 & 67,38 & 44,31 \\
\hline Setembro & 70,05 & 62,06 & 61,27 & 86,48 & 49,27 & 75,46 & 87,82 & 53,95 \\
\hline Totais & 1319,95 & 1168,23 & 1425,63 & 2325,35 & 833,11 & $\mathbf{1 0 7 4 , 0 7}$ & 1248,91 & 833,61 \\
\hline
\end{tabular}


Anexo C

Vazão média mensal segundo anos hídricos

\begin{tabular}{lcccccccc}
\hline & $\begin{array}{c}\mathbf{9 2 - 9 3} \\
\mathrm{m}^{3}\end{array}$ & $\begin{array}{c}\mathbf{9 3 - 9 4} \\
\mathrm{m}^{3}\end{array}$ & $\begin{array}{c}\mathbf{9 4 - 9 5} \\
\mathrm{m}^{3}\end{array}$ & $\begin{array}{c}\mathbf{9 5 - 9 6} \\
\mathrm{m}^{3}\end{array}$ & $\begin{array}{c}\mathbf{9 6 - 9 7} \\
\mathrm{m}^{3}\end{array}$ & $\begin{array}{c}\mathbf{9 7 - 9 8} \\
\mathrm{m}^{3}\end{array}$ & $\begin{array}{c}\mathbf{9 8 - 9 9} \\
\mathrm{m}^{3}\end{array}$ & $\begin{array}{c}\mathbf{0 0 - 0 1} \\
\mathrm{m}^{3}\end{array}$ \\
\hline Outubro & 21747,4 & 25131,4 & 28035,5 & 55313,8 & 26406,6 & 21594,5 & 47651,3 & 22665,8 \\
Novembro & 52059,6 & 20812,1 & 39225,5 & 46899,4 & 36063,1 & 31650,9 & 30224,3 & 34362,9 \\
Dezembro & 52800,8 & 28050,4 & 60575,7 & 48493,6 & 34192,7 & 25715,1 & 35669,5 & 42011,7 \\
Janeiro & 46936,6 & 32069,3 & 43225,5 & 101121,9 & 39913,4 & 51892,6 & 43165,5 & 37004,9 \\
Fevereiro & 53026,3 & 30576,2 & 83724,1 & 154014,8 & 29808,7 & 58409,5 & 70452,9 & 34448,2 \\
Março & 59801,0 & 68391,4 & 76789,3 & 165271,3 & 30204,9 & 57907,7 & 58009,3 & 32950,4 \\
Abril & 49182,3 & 67993,4 & 49959,8 & 103021,1 & 20610,2 & 39203,0 & 46612,3 & 20743,2 \\
Maio & 48389,6 & 49199,6 & 45662,4 & 58996,4 & 24025,0 & 29857,6 & 29726,4 & 20779,7 \\
Junho & 40125,4 & 38019,0 & 28228,3 & 42354,9 & 21675,8 & 19457,5 & 26205,9 & 14391,4 \\
Julho & 27885,5 & 30888,5 & 37783,8 & 37808,4 & 16012,0 & 19868,5 & 23299,1 & 16985,9 \\
Agosto & 17755,5 & 24566,1 & 19516,3 & 28072,2 & 15657,3 & 19718,3 & 25320,5 & 16652,1 \\
Setembro & 26326,1 & 23321,4 & 23025,6 & 32500,5 & 18513,9 & 28358,4 & 33002,5 & 20274,6 \\
Totais & $\mathbf{4 9 6 0 3 6 , 9}$ & $\mathbf{4 3 9 0 1 9 , 3}$ & $\mathbf{5 3 5 7 5 2 , 4}$ & $\mathbf{8 7 3 8 6 8 , 2}$ & $\mathbf{3 1 3 0 8 4 , 1}$ & $\mathbf{4 0 3 6 3 3 , 9}$ & $\mathbf{4 6 9 3 4 0 , 0}$ & $\mathbf{3 1 3 2 7 1 , 3}$ \\
\hline
\end{tabular}

Anexo D

Concentrações médias de sedimentos em suspensão em $\mathrm{mg}^{-1}$ e perdas de solo mensais em $\mathrm{kg} \mathrm{ha}^{-1}$.

\begin{tabular}{lrrrrrr}
\hline & $\begin{array}{c}\text { SST } \\
\mathrm{mgl}^{-1}\end{array}$ & \multicolumn{1}{c}{$\begin{array}{c}\text { SST } \\
\mathrm{kg} \mathrm{ha}^{-1}\end{array}$} & \multicolumn{1}{c}{$\begin{array}{c}\text { SSF } \\
\mathrm{mg} \mathrm{I}^{-1}\end{array}$} & $\begin{array}{c}\text { SSF } \\
\mathrm{kg} \mathrm{ha}^{-1}\end{array}$ & $\begin{array}{c}\text { SSV } \\
\mathrm{mg} \mathrm{I}^{-1}\end{array}$ & \multicolumn{1}{c}{$\begin{array}{c}\text { SSV } \\
\mathrm{kg} \mathrm{ha}^{-1}\end{array}$} \\
\hline Outubro & 4,2 & 2,5 & 1,2 & 0,7 & 3,0 & 1,8 \\
Novembro & 2,0 & 1,8 & 0,4 & 0,4 & 1,6 & 1,5 \\
Dezembro & 10,4 & 11,6 & 2,2 & 2,5 & 8,2 & 9,1 \\
Janeiro & 78,7 & 77,5 & 32,3 & 31,8 & 46,3 & 45,6 \\
Fevereiro & 49,8 & 45,7 & 13,9 & 12,8 & 35,9 & 32,9 \\
Março & 8,9 & 7,8 & 1,8 & 1,5 & 7,1 & 6,2 \\
Abril & 2,9 & 1,6 & 0,7 & 0,4 & 2,2 & 1,2 \\
Maio & 7,5 & 4,1 & 2,0 & 1,1 & 5,5 & 3,0 \\
Junho & 1,3 & 0,5 & 0,3 & 0,1 & 1,0 & 0,4 \\
Julho & 2,5 & 1,1 & 1,1 & 0,5 & 1,5 & 0,7 \\
Agosto & 16,0 & 7,1 & 1,2 & 0,5 & 14,8 & 6,6 \\
Setembro & 2,2 & 1,2 & 0,9 & 0,5 & 1,3 & 0,7 \\
\hline
\end{tabular}




\section{REFERÊNCIAS BIBLIOGRAFICAS}

AMERICAN PUBLIC HEALTH ASSOCIATION Standard Methods for the examination of water and wastewater. 19 ed. Washington: APHA, 1995. 1268p.

ANDERSON, H. W.; HOOVER, M. D.; REINHART, K. G. Forest and water: effects of forest management on floods, sedimentation, and water supply. USDA Forest Service PSW General Technical Report, n.18, p.1-115,1976.

ARCOVA, F.C.S. Balanço hídrico , características do deflúvio e calibragem de duas microbacias hidrográficas a Serra do Mar, SP. Piracicaba, 1996. 130 p. Dissertação (Mestrado) - Escola Superior de Agricultura "Luiz de Queiroz", Universidade de São Paulo.

ARCOVA, F.C.S; CICCO,V. Características do deflúvio de duas microbacias hidrográficas no Laboratorio de Hidrologia Florestal Walter Emmerich, Cunha SP. Revista Instituto Florestal de São Paulo, v.9, n.2, p.153-170, 1997.

ARCOVA, F.C.S.; CICCO, V. Qualidade da água de microbacias com diferentes usos do solo na região de Cunha, Estado de São Paulo. Scientia Forestalis, n.56, p.125134, dez.1999.

ARCOVA, F.C.S.; LIMA, W.P.; CICCO,V. Balanço hídrico de duas microbacias hidrográficas no laboratorio de Hidrología Florestal Walter Emmerich, São Paulo. Revista Instituto Florestal de São Paulo, v.10, n.1, p.39-51, 1998. 
ARCOVA, F.C.S.; CESAR,S.F.; CICCO,V. Qualidade da água em microbacias recobertas por floresta de mata atlántica, Cunha, SP. Revista Instituto Florestal de São Paulo, v.10, n.2, p.185-196, 1998.

BERTONI , J.; LOMBARDI NETO, F. Conservação do solo. São Paulo: Icone,1990. $335 \mathrm{p}$.

BINKLEY,D; BROWN, T.C. Management impacts on water quality of forest and rangelands. USDA Forest Service RM General Thecnical Report, n.239, p.1-114, 1993.

BRASIL. Ministerio de Agricultura, Serviço Nacional de Pesquisa Agonômica. Comissão de solos. Levantamento de reconhecimento dos solos do Estado de São Paulo, Rio de Janeiro, 1960. 634 p.

BROWN, G.W. Forestry and water quality. 2.ed. Corvalis: Oregon State University, 1988. $142 \mathrm{p}$.

BRUCE J.P.; CLARK R.H. Introduction to hydrometeorology. Oxford: Pergamon, 1975. 319 p.

BRUIJNZEEL L.A.; HAMILTON L.S Decision time for cloud forests. Paris: UNESCO, 2000. p.11-16: Fountain forest; myth or reality?. (IHP Humids Tropics Programme series, 13).

CÂMARA, C.D. Efeitos do corte raso do eucalipto sobre o balanço hídrico e a ciclagem de nutrientes em uma microbacia experimental. Piracicaba, 1999. 87 p. Dissertação (Mestrado). Escola Superior de Agricultura "Luiz de Queiroz", Universidade de São Paulo. 
CICCO, V.de; ARCOVA, F.C.S Projeto manejo de bacias hidrográficas experimentais Laboratório de Hidrologia Florestal Eng. Agr. Walter Emmerich Parque Estadual da Serra do Mar - Núcleo Cunha, SP. In: CURSO INTERNACIONAL SOBRE MANEJO FLORESTAL EM BACIAS HIDROGRÁFICAS, 5, Prog. de Treinamento para Terceros Paises - TCTP. São Paulo, 1999. Apostilas. São Paulo: Inst. Florestal de São Paulo - JICA - ABC, 1999.p.172-183.

CICCO, V. de; EMMERICH, W.; FARIA, A.J.; FUJIEDA, M. Projeto de pesquisas hidrológicas em floresta natural na Reserva estadual de Cunha - Determinação do balanço hídrico. In: SEMINARIO SOBRE ATUALIDADES E PERSPECTIVAS FLORESTAIS: A INFLUÊNCIA DAS FLORESTAS NO MANEJO DE BACIAS HIDROGRÁFICAS, 11, Curitiba - PR, 1984. Anais. Curitiba; EMBRAPA/PNPF, 1985. p.135-142.

CICCO, V. de; EMMERICH, W.; FUJIEDA, M. Determinação da curva-chave do vertedouro da bacia hidrográfica experimental "D” no Parque Estadual da Serra do Mar - Núcleo Cunha, SP. Boletim Técnico do Instituto Florestal de São Paulo, v.41, n.1, p.79-96, 1987.

CICCO, V.; ARCOVA, F.C.S.; SHIMOMISHI, P.Y. Estimativa da Evapotranspiração em bacia hidrográfica com floresta natural secundaria de mata Atlântica-SP. Revista Instituto Florestal de São Paulo, v.1, n.2, p.43-54,1989.

CICCO, V.; FUJIEDA, M. Pesquisa em manejo de bacias hidrográficas em São Paulo. In: CONGRESSO NACIONAL SOBRE ESSÊNCIAS NATIVAS, 2, São Paulo,1992. Anais, São Paulo: Revista Instituto Florestal de São Paulo, 1992. p.808-816.

CONSELHO NACIONAL DO MEIO AMBIENTE. Resoluções do CONAMA. 4. ed. Brasilia: IBAMA, 1992. 245 p. 
DOUGLASS. J.E.; SWANK, W.T. Effects of managements practices on water quality and quantity: Coweeta Hydrologic Laboratory, North Carolina. USDA Forest Service NH General Technical Report, n.13 p.1-13, 1975.

FUJIEDA, M. Watersheed management and planing methods. The International Course on Watershed Management in Forestry Area. Forestry and Forest Products Research Institute. Japan: Water Management Laboratoire, Forest Environment Division, 1987. 18 p.

FUJIEDA, M.; KUDOH, T.; MASHIMA Y. Hydrological processes in the Serra do Mar, São Paulo, Brasil. In: YOKOHAMA SYMPOSIUM. Yokohama, 1993. Proceedings. Yokohama: IAHS Publ., 1993. p.43-51.

FUJIEDA, M.; KUDOH, T.; CICCO, V., CALVARCHO, J.L. Hydrological processses at two subtropical forest catchments: the Serra do Mar, São Paulo, Brazil. Journal of Hydrology, v.196, p.26-46, 1997.

FURIAN, S.M. Morfogénèse / Pedogénèse en milieu tropical humide de la Serra do Mar, Brésil: Contribution de l'alteration e de la pedogése à une dynamique actuelle de glissement., Caen, 1994. 178 p. Thesis (Doutorado) - Université de Caen, France

FURIAN, S.M.; PFEIFER,R.M. Levantamento de reconhecimento do meio físico do Núcleo Cunha, SP. Boletin técnico Instituto Florestal de São Paulo, v.40, n.2, p.183-193, 1986.

GARCEZ, L. N.; ALVAREZ, G A. Hidrologia: Edgard Blücher, 1988. 291p.

GOODMAN, J. The Collection of Fog Drip., Water Resources Research, v.21, n.3, p.392-394, 1985.

HATCH, A.B. Some chemical properties of forest stream water in Western Australia. Perth: Forest Departament, 1976. 26p.(Bulletim, 89) 
HEM, J.D. Study and interpretation of the chemical characteristics of natural water. Washington: U.S. Geological Survey, 1970. 363 p.( Water Suppy Paper, 1473)

HERSCHY, R. W. Streamflow measurement. London: Elsevier Applied Science Publishers. 1985. 553 p.

HEWLET, J.D. Principles of Forest Hydrology. Athens: The University of Georgia Press, 1982. 183 p.

HOLDRIDGE, L.R. Ecologia basada en formas de vida. Costa Rica: JICA, 1982. $216 p$.

KAUFMANN, M.R.; GRAHAM, R.T.; BOYCE, D.A.Jr.; MOIR, W.H.; PERRY, L.; REYNOLDS R.T.; BASSET, R.L.; MEHLHOP, P; EDMINSTER, C.B.; BLOCK, W.M.; CORN, P.S. An Ecological Basis for Ecosystem Management. Fort Collins, CO: USDA Forest Service RM General Thecnical Report, n.246, p.1-22, mai.1994.

LEITÃO FILHO H.F. Aspectos taxonômicos das florestas do Estado de São Paulo. In: CONGRESSO NACIONAL SOBRE ESSENCIAS NATIVAS, Campos de Jordão, 1982. Anais. São Paulo: Silvicultura,1982, p. 197-206.

LENNOX, S.D.; FOY, R.H.; SMITH, R.V.; JORDAN, C. Estimating the contribution from agriculture to the fosforus load in surface water. In: TUNNEY,H.;CARTON, O.T.; BROOKES, P.C.; JOHNSTON,A.E. (Ed) Phosphorus loss from soil to water. New York: CAB International, 1997. p. 55-75.

LIMA, W.P. Hydrologic Behavior of two small watersheds in West Virginia undergoing natural reforestation. Ohio, 1971. 144 p. Thesis (Master of Science). Ohio State University. 
LIMA, W.P. Gerenciamento da qualidade ambiental: o papel do manejo de microbacia. In: SIMPÓSIO IPEF, 6, Piracicaba, 1996.Anais. Piracicaba: IPEF, 1996 v.1, p 3139.

LIMA , W.P.; ZAKIA,M.J.B. Indicadores hidrológicos em áreas florestais. IPEF. Serie Técnica, v.12, n.31, p.53-64,1998.

LULL, H. W. Y REINHART, K. G. Forest and floods in the Eastern United States., USDA Forest Service NE Res. Pap. n.226, p.1-94,1972.

Mc COOL, S., STANKEY, G. Representing the Future: A Framework for Evaluating the utility of indicators in the Search for Sustainable Forest Management. In: INTERNATIONAL CONFERENCE ON INDICATORS FOR SUSTAINABLE FOREST MANAGEMENT. Melbourne, 1998. Drafts papers and statements. Melbourne, Australia: IUFRO-CIFOR-FAO.13 p.

MUJERKI, S.; FAHMY, S.; WEBB, D. Fogwater collection System. Chile: Internacional Development Research Centre, Canadá - CONAF, 1993. 16 p.

O'LOUGHLIN, C. The forest and water relationship. New Zealand Forestry, v.39, n.3, p.26-30. 1994.

PLAMONDON, A.P. Augmentation de la concentration des sédiments en suspension suite à l'exploitation forestière et durée de l'efet. Canadian Journal Forestry Research. v.12, p.883-892. 1982

PLAMONDON, A.P. GONZALEZ, A., THOMASSIM Y. Effects of logging on water quality: comparison between two Quebec sites. In: CANADIAN HYDROLOGY SIMPOSIUM: 82, Frederickton, 1982. Anais. Frederickton: New-Brunswick, 1982. p.49-70.

PEREIRA, A.R.; VILLA NOVA, N.A.; SEDIYAM, G.C. Evapo(transpi)ração. Piracicaba: FEALQ,1997. 183p. 
PIRES , J.S.R.; SANTOS, J.E. Bacias Hidrográficas: Integração entre Meio Ambiente e Desenvolvimento. Ciência Hoje, v.19, n.110, p.40-45, 1995.

PINTO, N.L.S.; HOLTZ, A. C. T.; MARTINS, J.A. Hidrología de superficie. 2. ed. Curitiba: Centro de Estudos e Pesquisas de Hidráulica e Hidrologia da Universidade Federal do Paraná, 1973. 179 p.

PRAHBU, R.; RUITENBEEK, H.J.; BOYLE, T.J.B.; COLFER, C.J.P. Beetween voodoo science and adaptative management: the role and research needs for indicators of sustainable forest management, In: INTERNATIONAL CONFERENCE ON INDICATORS FOR SUSTAINABLE FOREST MANAGEMENT. Melbourne, 1998. Drafts papers and statements. Melbourne, Australia: IUFRO-CIFOR-FAO. $17 \mathrm{p}$.

RANZINI, M. Balanço hídrico, ciclagem de Nutrientes e Perdas de solo em duas microbacias reflorestadas com Eucalyptus saligna Smith, No vale do Paraíba, SP. Piracicaba, 1990. 99 p. Dissertação (Mestrado). Escola Superior de Agricultura "Luiz de Queiroz", Universidade de São Paulo.

RANZINI, M Modelagem hidrológica de uma microbacia florestada da Serra do Mar, SP, com o modelo TOPMODEL - simulação do comportamento hidrológico em função do corte raso. São Carlos, 2002. 116 p. Tese (Doutorado). Escola de Engenharia de São Carlos, Universidade de São Paulo.

REINHART, K.G.; PIERCE, R.S. Stream-gaging stations for research on small watersheeds USDA Forest Service, Agricultural Handbook, n.268, p.1-37,1964.

RIGHETTO, A.M. Hidrologia e recursos hídricos. São Carlos: EESC/USP, 1998. 840p. (Projeto REENGE)

SANTOS, E.H.M. Descarga de sedimentos em suspensão por três rios da bacia Hidrográfica do Alto Rio Grande. Lavras, 1998. 58 p. Dissertação (Mestrado). Universidade Federal de Lavras. 
SARRAILH, J.M. Mise en valeur de l'ecosystème forestier guyanais (Opération ECEREX) Écologie e aménagement rural. Cayenne: Inst. Nac. de la Recherche Agronomique, Centre Technique tropical, 1990. 273 p.

SCARDUA, F.P. Caracterização hidrológica de uma microbacia hidrográfica experimental da Estação Experimental de Ciências Florestais de Itatinga. Piracicaba, 1994. 93 p. Dissertação (Mestrado). Escola Superior de Agricultura "Luiz de Queiroz", Universidade de São Paulo.

SÉ, J. O rio Monjolinho e sua bacia hidrográfica como integradores de sistemas ecológicos: un conjunto de informações para o início de um processo de pesquisas ecológicas de educação, planejamento e gerenciamento ambientais a longo prazo. São Carlos, 1992 Dissertação (Mestrado) - Escola de Engenharia de São Carlos, Universidade de São Paulo.

SHIMOMICHI, P. Y.; CICCO, V. de; ARCOVA, F. C. S.; FARIA, A J. Correlação entre métodos de cálculo de precipitação média mensal em bacia hidrográfica experimental. Boletim Técnico do Instituto Florestal de São Paulo, v.41, n.1, p.126, 1987.

STEDNICK, J.D. Monitoring the effects of timber harvest on water yield. Journal of Hydrology, n.176, p.79-95,1996.

SWIFT L.W.JUNIOR. Forest access roads: design, maintenance and soil loss. In: SWANK, W.T; CROSSLEY D.A. JUNIOR. Forest Hydrology and Ecology at Coweeta. New York: Springer-Verlang, 1988. p.35-55. (Ecological Studies)

THORNTHWAITE, C.W.; MATHER, J.R. The water balance. Publications in Climatology. New Jersey: Drexel Institute of Technology, 1955. 104p.

TOLEDO. L.G; NICOLELLA, G. Índice de qualidade de água em microbacia sob uso agrícola e urbano. Scientia Agrícola, v.59,n.1, p.181-186, jan./mar.2002 
TUCCI, C.E.M. Hidrologia, Ciência e Aplicação. Porto Alegre: Ed Universidade/UFRGS; ABRH, 2000. 943 p.

VILAS BOAS, S.; PFEIFER, R.M.; CARVALHO, W.A. Relações entre parâmetros dimensionais de bacias hidrográficas e solos do Parque Estadual da Serra do MarNúcleo Cunha, SP. Silvicultura, n.20/22, p.57-67, 1986/88.

VITAL, A.N.T., LIMA, W.P., CAMARGO, F.R.A. Efeitos do corte raso de plantações de Eucaliptus sobre o balanço hídrico, a qualidade da água e as perdas de solo e de nutrientes em uma microbacia no Vale do paraíba, SP. Scientia Forestalis. n.55, p.5-16, jun.1999.

VOGELMANN, H.W. Fog precipitation in the cloud forests of Eastern México. BioScience v.23,n.2, p.96-100, 1973.

WETZWL, R.G.; LIKENS, G.E. Limnological analyses. New York: Springer-Verlag, 1991. 331p.

ZADROGA, F. The hydrological Importance of a Montane Cloud Forest Area of Costa Rica. In: LAL, R.; RUSSELL E.W. (Ed.) Tropical Agricultural Hydrology. Chichester: John Wiley,1981. cap. 2, p.59-73.

ZAKIA, M.J.B. O balanço hídrico levando-se em conta o sistema solo-planta-atmosfera de quatro tipos de coberturas vegetais na região de Grão Mogol, MG. Piracicaba, 1987. 136 p. Dissertação (Mestrado). Escola Superior de Agricultura "Luiz de Queiroz”, Universidade de São Paulo.

ZIMMERMANN, L.; ZIMMERMANN F. Fog deposition to Norway Spruce stands at high-elevation sites in the Eastern Erzgebirge (Germany). Journal of Hydrology, n.256, p.166-175, 2002. 